Prepared in cooperation with the Arkansas Natural Resources Commission and the Arkansas Geological Survey

\title{
Water Levels and Water Quality in the Sparta-Memphis Aquifer (Middle Claiborne Aquifer) in Arkansas, Spring- Summer 2009
}

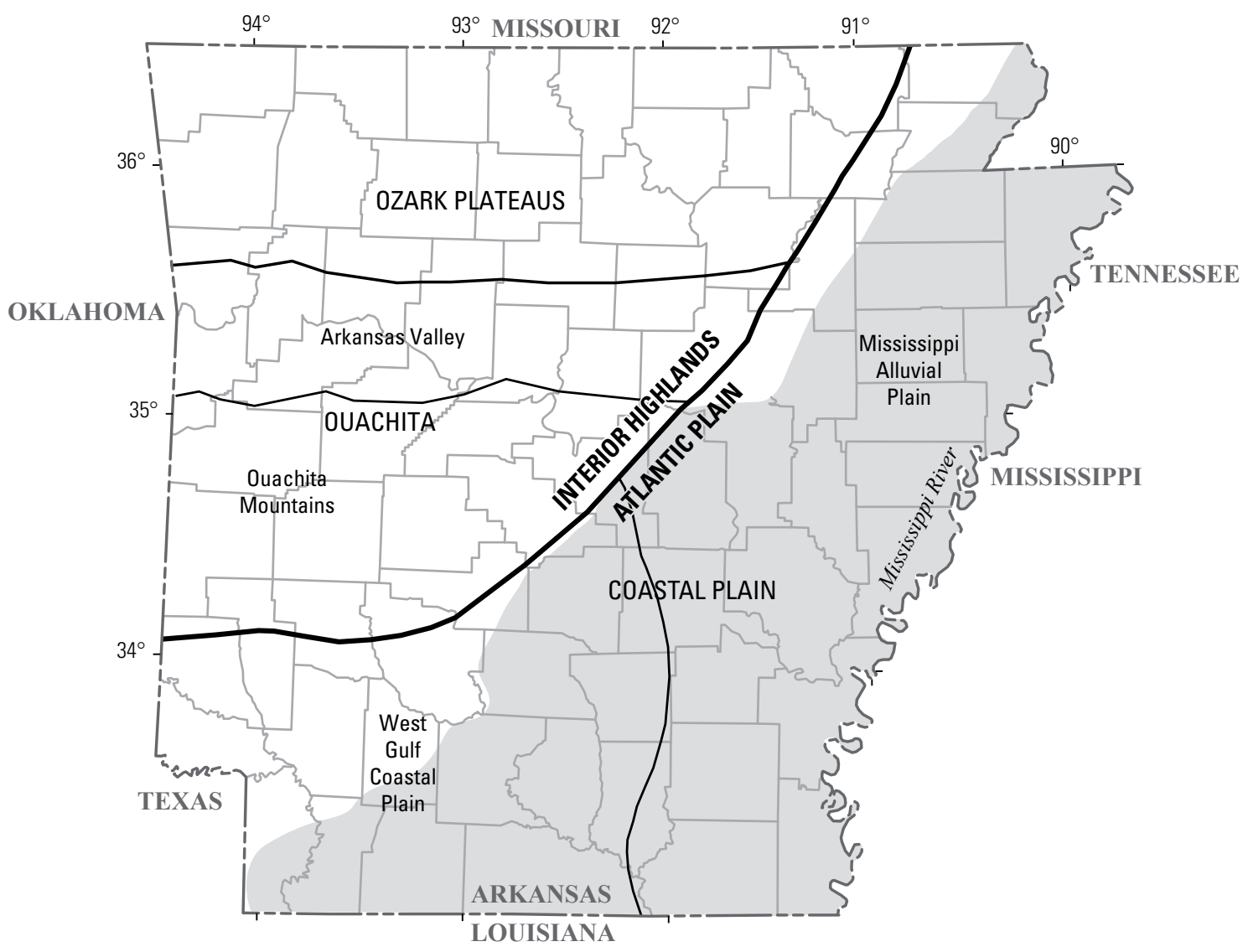

Scientific Investigations Report 2013-5100

U.S. Department of the Interior

U.S. Geological Survey 



\section{Water Levels and Water Quality in the Sparta-Memphis Aquifer (Middle Claiborne Aquifer) in Arkansas, Spring-Summer 2009}

By T.P. Schrader

Prepared in cooperation with the Arkansas Natural Resources Commission and the Arkansas Geological Survey

Scientific Investigations Report 2013-5100 


\section{U.S. Department of the Interior \\ SALLY JEWELL, Secretary}

\section{U.S. Geological Survey \\ Suzette M. Kimball, Acting Director}

\section{U.S. Geological Survey, Reston, Virginia: 2013}

For more information on the USGS — the Federal source for science about the Earth, its natural and living resources, natural hazards, and the environment, visit http://www.usgs.gov or call 1-888-ASK-USGS.

For an overview of USGS information products, including maps, imagery, and publications, visit http://www.usgs.gov/pubprod

To order this and other USGS information products, visit http://store.usgs.gov

Any use of trade, firm, or product names is for descriptive purposes only and does not imply endorsement by the U.S. Government.

Although this information product, for the most part, is in the public domain, it also may contain copyrighted materials as noted in the text. Permission to reproduce copyrighted items must be secured from the copyright owner.

Suggested citation:

Schrader, T.P., 2013, Water levels and water quality in the Sparta-Memphis aquifer (middle Claiborne aquifer) in Arkansas, spring-summer 2009: U.S. Geological Survey Scientific Investigations Report 2013-5100, 53 p., 2 plates, http://pubs.usgs.gov/sir/2013/5100/. 


\section{Contents}

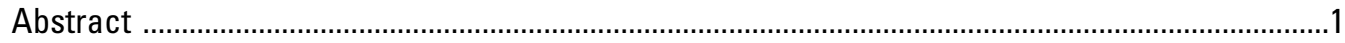

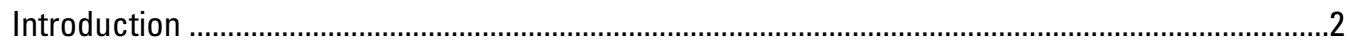

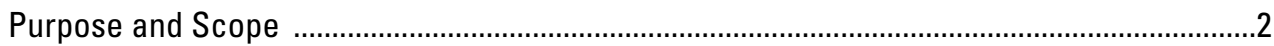

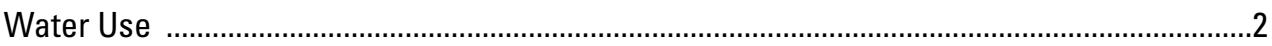

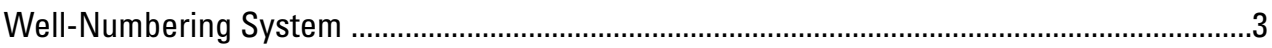

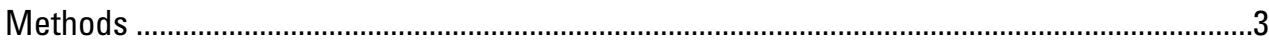

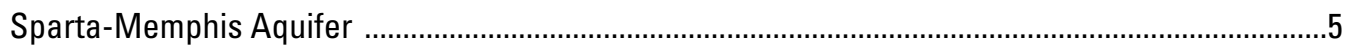

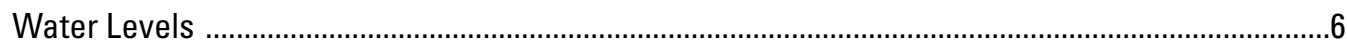

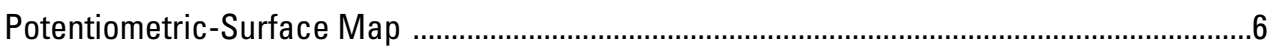

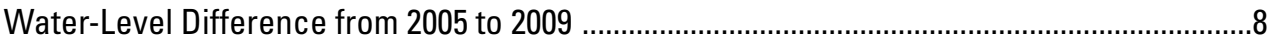

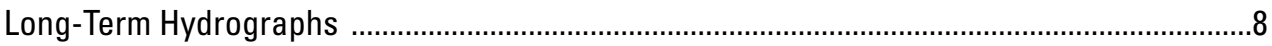

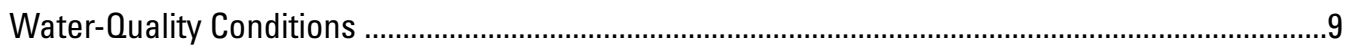

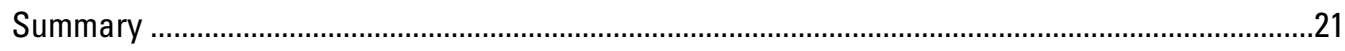

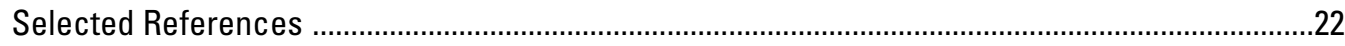

Appendixes

1. Water-Level Data Collected during Spring 2009 from Wells Completed in the Sparta-Memphis Aquifer in Arkansas ...........................................................................25

2. Difference in Water Level from 2005 to 2009 in the Sparta-Memphis Aquifer in

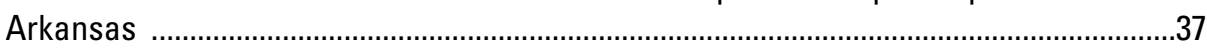

3. Specific Conductance, Temperature, and pH Data from Wells Completed in the Sparta-Memphis Aquifer in Arkansas, Summer 2009

\section{Plates}

[In pocket]

1. Map showing potentiometric surface for the Sparta-Memphis aquifer in Arkansas, 2009

2. Map showing water-level difference for the Sparta-Memphis aquifer in Arkansas from 2005 to 2009

\section{Figures}

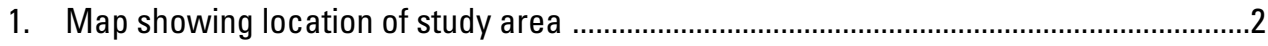

2. Graph showing water use in the Sparta-Memphis aquifer in Arkansas, 1965-2005 .......3

3. Diagram showing well-numbering system ..................................................................4

4. Water-level hydrographs for selected wells completed in the Sparta-Memphis aquifer in Arkansas .............................................................................................. 10

5. Graph showing distribution of specific conductance in samples from the SpartaMemphis aquifer in 2005 and 2009 in Arkansas 


\section{Tables}

1. Stratigraphic correlation in the northern and southern parts of Arkansas ..

2. Number of wells, range, mean, median, and correlation coefficient, $R^{2}$, of annual rise-decline in water level by county for wells in the Sparta-Memphis aquifer, 1985-2009

\section{Conversion Factors}

Inch/Pound to SI

\begin{tabular}{lcl}
\hline \multicolumn{1}{c}{ Multiply } & By & \multicolumn{1}{c}{ To obtain } \\
\hline & Length & meter $(\mathrm{m})$ \\
foot $(\mathrm{ft})$ & 0.3048 & kilometer $(\mathrm{km})$ \\
mile (mi) & 1.609 & \\
\hline & Flow rate & meter per year $(\mathrm{m} / \mathrm{yr})$ \\
\hline foot per year $(\mathrm{ft} / \mathrm{yr})$ & 0.3048 & cubic meter per second $\left(\mathrm{m}^{3} / \mathrm{s}\right)$ \\
million gallons per day $(\mathrm{Mgal} / \mathrm{d})$ & 0.04381 & \\
\hline
\end{tabular}

Temperature in degrees Celsius $\left({ }^{\circ} \mathrm{C}\right)$ may be converted to degrees Fahrenheit $\left({ }^{\circ} \mathrm{F}\right)$ as follows:

${ }^{\circ} \mathrm{F}=\left(1.8 x^{\circ} \mathrm{C}\right)+32$

Temperature in degrees Fahrenheit $\left({ }^{\circ} \mathrm{F}\right)$ may be converted to degrees Celsius $\left({ }^{\circ} \mathrm{C}\right)$ as follows:

${ }^{\circ} \mathrm{C}=\left({ }^{\circ} \mathrm{F}-32\right) / 1.8$

Vertical coordinate information is referenced to the National Geodetic Vertical Datum of 1929 (NGVD 29).

Horizontal coordinate information is referenced to North American Datum of 1983 (NAD 83).

Altitude, as used in this report, refers to distance above the vertical datum.

Specific conductance is given in microsiemens per centimeter at 25 degrees Celsius $(\mu \mathrm{S} / \mathrm{cm}$ at $\left.25^{\circ} \mathrm{C}\right)$.

Concentrations of chemical constituents in water are given either in milligrams per liter (mg/L) or micrograms per liter $(\mu \mathrm{g} / \mathrm{L})$. 


\title{
Water Levels and Water Quality in the Sparta-Memphis Aquifer (Middle Claiborne Aquifer) in Arkansas, Spring- Summer 2009
}

\author{
By T.P. Schrader
}

\begin{abstract}
The U.S. Geological Survey in cooperation with the Arkansas Natural Resources Commission and the Arkansas Geological Survey has monitored water levels in the Sparta Sand of Claiborne Group and Memphis Sand of Claiborne Group (herein referred to as the Sparta Sand and the Memphis Sand, respectively) since the 1920s. Groundwater withdrawals have increased while water levels have declined since monitoring was initiated. Herein, aquifers in the Sparta Sand and Memphis Sand will be referred to as the SpartaMemphis aquifer throughout Arkansas. During the spring of 2009, 324 water levels were measured in wells completed in the Sparta-Memphis aquifer and used to produce a regional potentiometric-surface map. During the summer of 2009, 64 water-quality samples were collected and measured for specific conductance, temperature, and $\mathrm{pH}$ from wells completed in the Sparta-Memphis aquifer.

The regional direction of groundwater flow in the Sparta-Memphis aquifer is generally to the south-southeast in the northern half of Arkansas and to the east and south in the southern half of Arkansas, away from the outcrop area except where affected by large groundwater withdrawals. The highest and lowest water-level altitudes measured in the Sparta-Memphis aquifer were 325 feet above and 157 feet below National Geodetic Vertical Datum of 1929, respectively.

Eight depressions (generally represented by closed contours) are located in the following counties: Bradley; Ashley; Calhoun; Cleveland; Columbia; Arkansas, Jefferson, Lincoln, and Prairie; Cross and Poinsett; and Union. Two large depressions shown on the 2009 potentiometric-surface map, centered in Jefferson and Union Counties, are the result of large withdrawals for industrial, irrigation, or public supply. The depression centered in Jefferson County deepened and expanded in recent years into Arkansas and Prairie Counties. The area enclosed within the 40 -foot contour on the 2009 potentiometric-surface map has expanded south to the Drew County line and moved west from the intersection of Arkansas, Jefferson, and Lincoln Counties when compared with the 2007 potentiometric-surface
\end{abstract}

map. To the north, east, and west, the 40 -foot contour is comparable to the 2007 potentiometric-surface map. The lowest water-level altitude measurement during 2009 in the center of the depression in Union County represents a rise of 42 feet since 2003. The area enclosed by the lowest altitude contour, 140 feet below National Geodetic Vertical Datum of 1929, on the 2009 potentiometric-surface map is about half the area on the 2007 potentiometric-surface map. In the depression in western Poinsett and Cross Counties, the 140-foot contour extended north to the Poinsett-Craighead County line and south across Cross County about two-thirds of the distance to the St. Francis County line.

A water-level difference map was constructed using water-level measurements made during 2005 and 2009 from 309 wells. The difference in water level between 2005 and 2009 ranged from -74.6 to 60.2 feet. Areas with a general rise in water levels occur in central Columbia County, southern Jefferson County, and most of Union County. In the area around west-central Union County, water levels rose as much as 60.2 feet with water levels in 18 wells rising 20 feet or more, representing an average annual rise of 5 feet or more. Water levels generally declined throughout most of the rest of Arkansas.

Hydrographs were constructed using a minimum of 25 years of water-level measurements at each of 206 wells. During the period 1985-2009, mean annual water levels rose in Calhoun, Columbia, Lafayette, and Union Counties, about 1.3 feet per year (ft/yr), $0.2 \mathrm{ft} / \mathrm{yr}, 0.1 \mathrm{ft} / \mathrm{yr}$, and $0.6 \mathrm{ft} / \mathrm{yr}$, respectively. Mean annual water-level declines between 0.0 and $2.3 \mathrm{ft} / \mathrm{yr}$ occurred in all other counties. In western Arkansas County, water-level altitudes in a continuously monitored well declined 60 feet during the irrigation season (April to September).

Specific conductance ranged from 43 microsiemens per centimeter at 25 degrees Celsius $(\mu \mathrm{S} / \mathrm{cm})$ in Ouachita County to $1,230 \mu \mathrm{S} / \mathrm{cm}$ in Phillips County. The mean specific conductance was $392 \mu \mathrm{S} / \mathrm{cm}$. Although there is a regional increase in specific conductance to the east and south, specific conductance values greater than $700 \mu \mathrm{S} / \mathrm{cm}$ occurred in samples from wells in Arkansas, Ashley, Monroe, Phillips, and Union Counties. 


\section{Introduction}

The U.S. Geological Survey (USGS) in cooperation with the Arkansas Natural Resources Commission (ANRC) and the Arkansas Geological Survey has monitored water levels in the Sparta Sand of Claiborne Group and Memphis Sand of Claiborne Group (herein referred to as the Sparta Sand and the Memphis Sand, respectively) since the 1920s. Groundwater withdrawals generally have increased while water levels generally have declined since monitoring was initiated. Since 1980, the USGS has produced reports, at various intervals, that describe groundwater conditions in the Sparta Sand and Memphis Sand aquifers in Arkansas. These reports are the products of a continuing project that includes the groundwater networks and basic data collection for Arkansas to provide information for the management of this valuable resource.

The study area (fig. 1) in Arkansas is bounded on the north by the Missouri State line, on the east by the Tennessee and Mississippi State lines, and on the south by the Louisiana State line. The western boundary is defined as the western extent of the outcrop and subcrop (Hosman, 1982) of the Sparta Sand and the Memphis Sand. Water levels in the aquifer in the Sparta Sand generally correlate with those in the aquifer in the Memphis Sand; therefore, the water-bearing formations are considered to be one hydrologic unit (Stanton, 1997).

\section{Purpose and Scope}

This report presents water-level and water-quality conditions in the aquifers in the Sparta Sand and the Memphis Sand in Arkansas. Herein, aquifers in the Sparta Sand and Memphis Sand will be referred to as the Sparta-Memphis aquifer. During the spring of 2009, water levels were measured in 324 wells completed in the Sparta-Memphis aquifer. These measurements were used to describe the potentiometric surface of the Sparta-Memphis aquifer. During the summer of 2009, 64 water-quality samples were collected and measured for specific conductance, temperature, and $\mathrm{pH}$. This report presents a potentiometric-surface map, a water-level difference map comparing water levels from 2005 to 2009 , selected water-level hydrographs, and a graph showing the distribution of specific conductance in samples.

\section{Water Use}

Water use in the Sparta-Memphis aquifer in Arkansas generally has increased from 1965 to 2000 (fig. 2). In 1965, water use in the Sparta-Memphis aquifer was about 112 million gallons per day (Mgal/d), increasing to 142 $\mathrm{Mgal} / \mathrm{d}$ in 1970, $144 \mathrm{Mgal} / \mathrm{d}$ in 1975, and $185 \mathrm{Mgal} / \mathrm{d}$ in 1980 (Halberg, and Stephens, 1966; Halberg, 1972; Halberg, 1977; Holland and Ludwig, 1981). In 1985, water use declined to

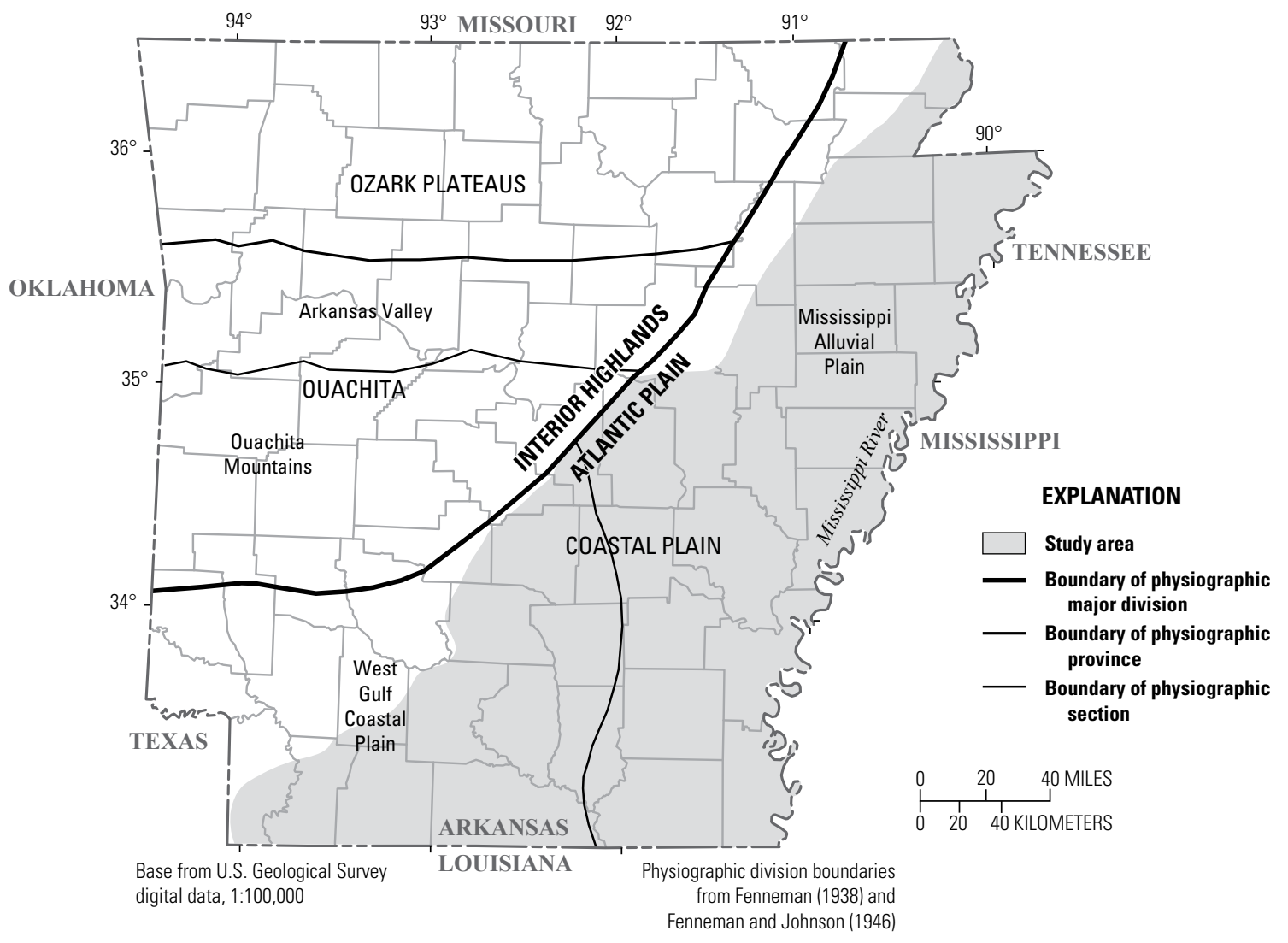

Figure 1. Location of study area. 


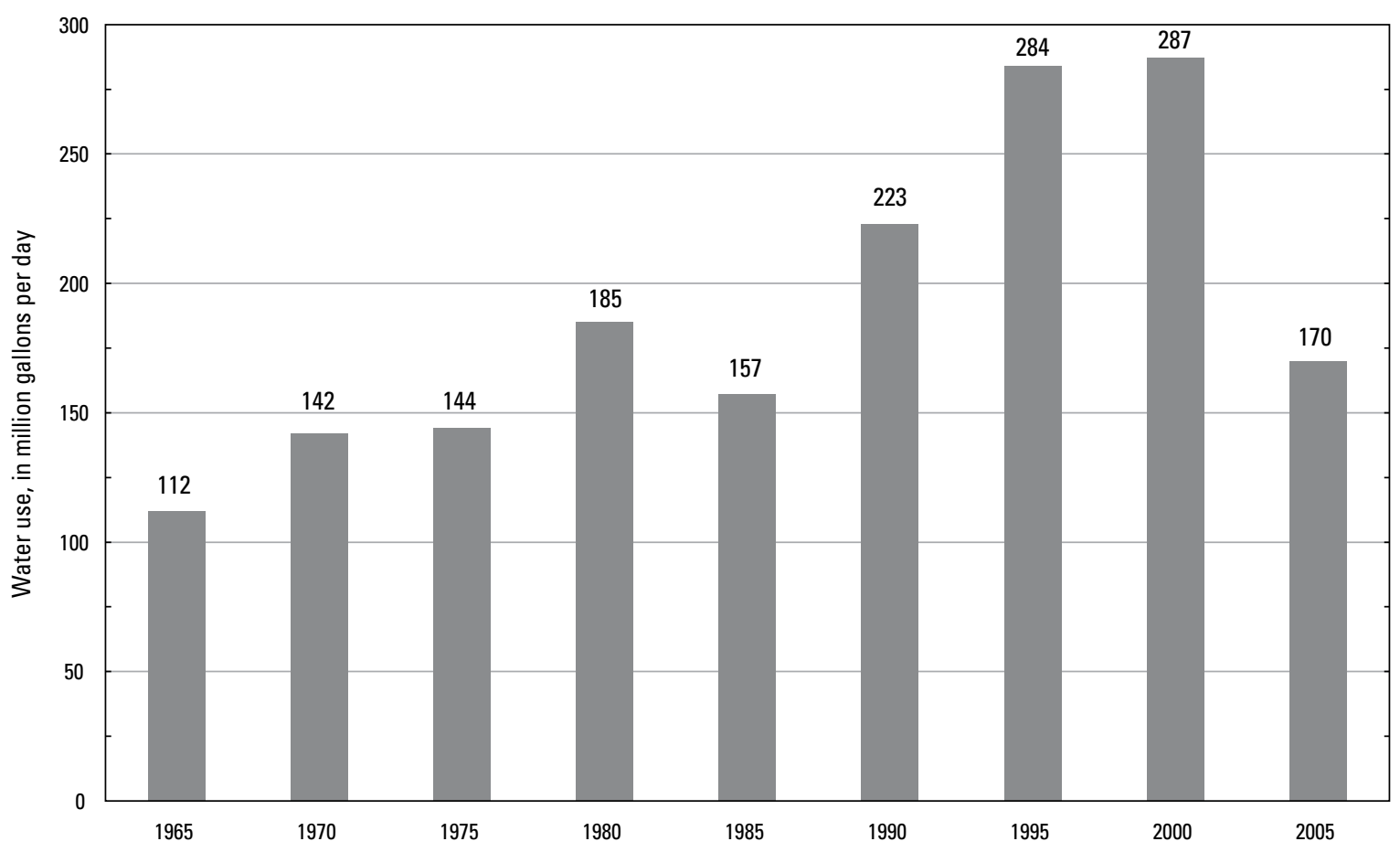

Figure 2. Water use in the Sparta-Memphis aquifer in Arkansas, 1965-2005.

about $157 \mathrm{Mgal} / \mathrm{d}$ (Holland, 1987). Water use in the SpartaMemphis aquifer was about $223 \mathrm{Mgal} / \mathrm{d}$ in 1990 and 284 $\mathrm{Mgal} / \mathrm{d}$ in 1995 (Holland, 1993, 1999). In 2000, water use in the Sparta-Memphis aquifer was about $287 \mathrm{Mgal} / \mathrm{d}$ (Holland, 2004), an increase of about 156 percent from 1965. In 2005, water use in the Sparta-Memphis aquifer declined to about 170 Mgal/d (Holland, 2007).

Water use from the Sparta-Memphis aquifer in 2005 was divided into three primary categories - irrigation, public supply, and industrial. Irrigation used about 61.0 $\mathrm{Mgal} / \mathrm{d}$ (35.9 percent), public supply used about $58.9 \mathrm{Mgal} / \mathrm{d}$ (34.6 percent), and industrial used about $48.0 \mathrm{Mgal} / \mathrm{d}(28.2$ percent). Agriculture and power generation each accounted for less than 1 percent of the water use in the Sparta-Memphis aquifer in Arkansas in 2005. Major pumping centers that use the Sparta-Memphis aquifer for public supply and industry occur in Columbia, Jefferson, and Union Counties. Arkansas, Craighead, Cross, Desha, Lonoke, Monroe, Phillips, and Prairie Counties accounted for the majority of the water withdrawn for irrigation from the Sparta-Memphis aquifer in 2005 (Holland, 2007).

\section{Well-Numbering System}

The well-numbering system used in this report is based upon the Federal land survey used in Arkansas. The component parts of a well number are the township designation; the range designation; the section number; three-letter designation that indicates, respectively, the quarter section, the quarter-quarter section, and the quarter-quarterquarter section in which the well is located; and the sequence number of the well in the quarter-quarter-quarter section. The letters are assigned counterclockwise, beginning with " $\mathrm{A}$ " in the northeast quarter or quarter-quarter or quarter-quarterquarter section in which the well is located. For example, well 01S03W04BBD16 (fig. 3) is located in Township 1 South, Range 3 West, in the southeast quarter of the northwest quarter of the northwest quarter of section 4 . This well is the 16th well in this quarter-quarter-quarter section of section 4 from which data were collected.

\section{Methods}

USGS and ANRC personnel measured water levels from March to May 2009 from wells completed in the SpartaMemphis aquifer. Measurements were made using steel or electric tapes graduated in hundredths of a foot. The steel and electric tapes were calibrated prior to collecting water-level measurements. Calibration was performed by comparing the steel or electric tapes to a standardized steel tape used only for calibration.

Well locations were verified using Global Positioning System (GPS) receivers to acquire the horizontal-coordinate information, latitude and longitude, based on the North American Datum of 1983. The latitude and longitude of the wells in Arkansas were recorded from a GPS receiver 


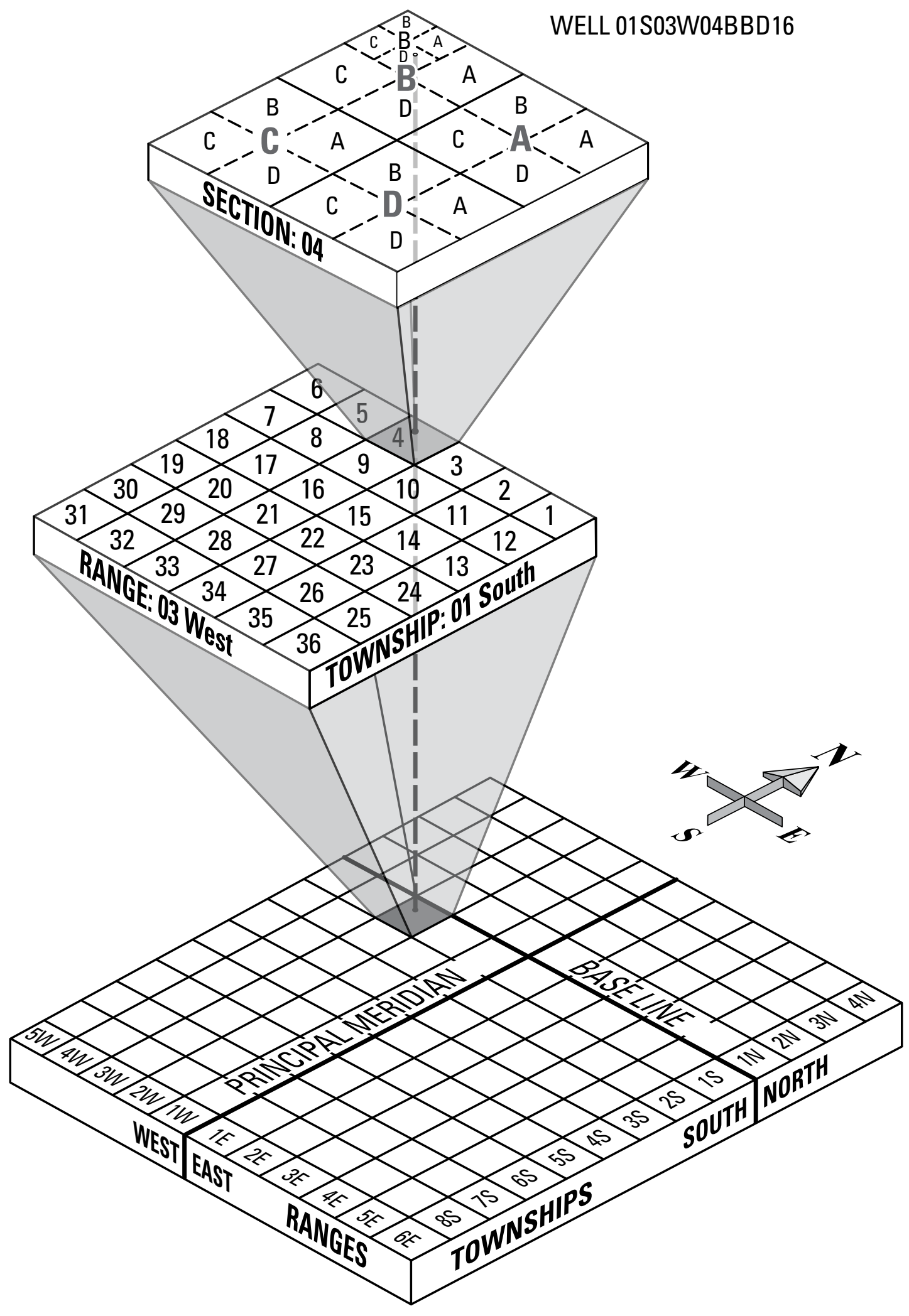

Figure 3. Well-numbering system. 
accurate to one-tenth of a second of latitude and longitude (approximately 10-20 feet (ft)). The latitude and longitude of each well were transferred to topographic maps and the altitude of each well (National Geodetic Vertical Datum of 1929 [NGVD 29]) was determined from the topographic contours at the location on the map. Altitude is accurate to about 2.5 to $5 \mathrm{ft}$, or half the contour interval on the map.

Two methods for calculating the annual rise or decline of water levels are used. One method is to take the difference between the final and initial water levels and divide by the period of time. This method uses two measurements and calculated values are dependent solely on the final and initial water levels. A second method uses the linear regression of water levels and time of measurement to calculate the annual rise or decline in water level. Linear regression is more robust because it includes all the measurements to determine the trend line, resulting in a value that is dependent on all water levels during the period of record. The slope, $\beta$, of the line is the annual rise or decline in water level. The intercept, $\beta_{0}$, would be the water level in the year 1900, the origin for the graph. The predevelopment water level will not be discussed as this condition cannot be demonstrated. The $\mathrm{R}^{2}$ term is the coefficient of determination, the correlation coefficient, or the fraction of variance explained by the regression. The $\mathrm{R}^{2}$ value gives the proportions of the total variability that can be accounted by the independent variable (Helsel and Hirsch, 1992). Values of $R^{2}$ can range from 0.00 to 1.00 . A large value of $R^{2}$ can indicate a linear change in water level. A low value of $R^{2}$ can indicate a sporadic change in water level. The equation of the regression line or line of best fit, $\mathrm{Y}=\mathrm{aX}+\mathrm{b}$, may be written as:

$$
h=\beta t+\beta_{0}
$$

where

$$
\begin{array}{cl}
h & \text { is water level altitude, in feet; } \\
\beta & \text { is the slope of the line, in feet per year; } \\
t & \text { is time, in years; and } \\
\beta_{0} & \text { is the y-intercept or water-level altitude at } \\
& \text { time equal to } 1,900, \text { in feet. }
\end{array}
$$

Five assumptions are associated with linear regression: (1) Y is linearly related to X, (2) data used to fit the linear regression are representative of data of interest, (3) variance of the residuals is constant and does not depend on $\mathrm{X}$ or on anything else, (4) the residuals are independent, and (5) the residuals are normally distributed. The assumption of a normal distribution is involved only when testing hypotheses, requiring the residuals from the regression equation to be normally distributed (Helsel and Hirsch, 1992).

Water-quality samples were collected for specific conductance, temperature, and $\mathrm{pH}$ using the procedures described in the National Field Manual for the Collection of Water-Quality Data (U.S. Geological Survey, variously dated). Wells were purged a minimum of three-casing volumes, and specific conductance, temperature, and $\mathrm{pH}$ were monitored until measurements stabilized (Fishman and Friedman, 1989). Casing volumes for the wells were calculated from the well casing diameter, depth to water, and well depth. The crosssectional area of the casing is calculated from the casing diameter, and the height of the water column is determined by subtracting the depth to water from the well depth. The area and the height of the water column are multiplied for a casing volume in cubic feet, then converted to gallons. The calculated purge volume at each well was then divided by the pumping rate to determine the minimum pumping time for purging. Pumping rates ranged from 100 to 550 gallons per minute.

Specific conductance and $\mathrm{pH}$ were measured from selected wells using a specific-conductance and $\mathrm{pH}$ meter with temperature compensation. The specific-conductance and $\mathrm{pH}$ meter was calibrated twice daily by comparing the measurement of two specific conductance calibration standards. Specific conductance is a measure of the electrical conductance of a solution. As the dissolved-solids concentration in groundwater increases, specific conductance increases. Most of the wells sampled were public supply and industrial wells.

\section{Sparta-Memphis Aquifer}

The Sparta Sand and Memphis Sand (table 1) of Eocene age mainly consist of fine to medium sand in Arkansas with some silt, clay, and lignite in the upper parts. Sands in the Sparta Sand were deposited by shifting streams on a deltaicfluvial flood plain (Payne, 1968). These sands mostly are interconnected, but separately identifiable sands can be traced for short distances (Snider and others, 1972). The Cook Mountain Formation of Claiborne Group overlies the Sparta Sand and Memphis Sand and serves as an upper confining unit (table 1). The permeable units of the Sparta Sand and the Memphis Sand compose the Sparta and Memphis aquifers.

The Sparta Sand is composed of a sequence of alternating sand and clay beds between the massive clays of the overlying Cook Mountain Formation and the underlying Cane River Formation of Claiborne Group confining units (Hosman and others, 1968) shown in table 1. The Sparta Sand is in the southern part of the study area (south of about 35 degrees latitude, pl. 1) where the Cane River Formation is composed predominantly of clay. The Memphis Sand is in the northern part of the study area (north of about 35 degrees latitude) where the Cane River Formation or equivalent facies is composed predominantly of sand. Moving south to north in the area, the Cane River Formation undergoes a facies change northward at about 35 degrees latitude, and the marine clays become sand. The transitional zone of interfingering sands and clays is narrow. The northern sand facies of the Cane River Formation is the middle part of the Memphis Sand (Hosman and others, 1968). In the southern area, the Claiborne Group is subdivided into the Carrizo Sand, Cane River Formation, Sparta Sand, Cook Mountain Formation, and the Cockfield 
Table 1. Stratigraphic correlation in the northern and southern parts of Arkansas.

[Table constructed from Petersen, Broom, and Bush, 1985; Scheiderer and others, 2008]

\begin{tabular}{|c|c|c|c|c|c|}
\hline Series & Group & $\begin{array}{l}\text { Formations in the south } \\
\text { part of Arkansas }\end{array}$ & $\begin{array}{l}\text { Formations in the north } \\
\text { part of Arkansas }\end{array}$ & \multicolumn{2}{|c|}{ Hydrogeological units } \\
\hline \multirow{7}{*}{ Eocene } & Jackson & Undifferentiated & Undifferentiated & Vicksburg-Jackson confining uni & \\
\hline & \multirow{6}{*}{ Claiborne } & Cockfield Formation & Cockfield Formation & Upper Claiborne aquifer & \\
\hline & & Cook Mountain Formation & Cook Mountain Formation & Middle Claiborne confining unit & \\
\hline & & Sparta Sand & \multirow{4}{*}{ Memphis Sand } & & \multirow{4}{*}{$\begin{array}{l}\text { Middle Claiborne } \\
\text { aquifer (Sparta- } \\
\text { Memphis) }\end{array}$} \\
\hline & & & & & \\
\hline & & Cane River Formation & & Lower Claiborne confining unit & \\
\hline & & Carrizo Sand & & Lower Claiborne aquifer & \\
\hline \multirow{2}{*}{ Paleocene } & Wilcox & Wilcox Group & Wilcox Group & \multicolumn{2}{|l|}{ Lower Wilcox aquifer } \\
\hline & Midway & Undifferentiated & Undifferentiated & \multicolumn{2}{|l|}{ Midway confining unit } \\
\hline
\end{tabular}

Formation (table 1). The equivalent section in the northern area is subdivided into the Memphis Sand, the Cook Mountain Formation, and the Cockfield Formation. The Memphis Sand in the northern area is equivalent to the Carrizo Sand, the Cane River Formation, and the Sparta Sand in the southern area. The Memphis Sand is underlain by a thick layer of clay in the upper part of the Wilcox Group (Hosman and others, 1968).

The Sparta Sand and Memphis Sand generally thicken and groundwater increases in salinity as depth increases to the southeast. The Sparta Sand is 50 to $200 \mathrm{ft}$ thick within the outcrop area (along the western limit) and thickens easterly to nearly $900 \mathrm{ft}$. The Sparta Sand contains freshwater throughout most of its extent in Arkansas. However, saltwater is present in the extreme southeastern part of the State in parts of Ashley, Chicot, and Union Counties (Payne, 1968).

\section{Water Levels}

Water-level measurements in wells screened in the Sparta-Memphis aquifer (appendix 1) were used to produce a regional potentiometric-surface map (pl. 1), water-level difference map (pl. 2), and hydrographs (fig. 4). Water levels measured during the spring of 2009 were subtracted from water levels measured during the spring of 2005 at selected Sparta-Memphis aquifer wells and used to create the waterlevel difference map (pl. 2). Hydrographs were generated for 206 wells (that have water-level measurements with a minimum 25-year period of record, with one exception at well 04S05W05ACC1 in Arkansas County that is a continuous well with 3 years of data) and compiled by county; hydrographs for 29 of the wells are shown in figure 4 . The water levels shown in the hydrographs indicate long-term changes in hydrologic conditions. Long term water-level declines shown in the hydrographs reflect the response of the groundwater flow system to stresses caused by groundwater pumping.

\section{Potentiometric-Surface Map}

A potentiometric-surface map was constructed using 324 water-level measurements (appendix 1) from wells completed in the Sparta-Memphis aquifer during spring 2009. Hydrologic principles, water-use data, and historical information were used in conjunction with the water-level data to delineate the potentiometric-surface contours. The number and location of wells used to construct potentiometric-surface maps differ from year to year.

The potentiometric-surface map of the Sparta-Memphis aquifer shows the altitude at which water would have stood in tightly cased wells completed in the aquifer (pl. 1). The surface is mapped by determining the altitude of the water levels measured in the wells and is represented on the map by contours that connect points of equal water-level altitude. The general direction of groundwater flow in the Sparta-Memphis aquifer is perpendicular to the contours in the direction of decreasing hydraulic gradient.

The regional direction of groundwater flow in the Sparta-Memphis aquifer is generally to the south-southeast in the northern half of Arkansas and to the east and south in the southern half of Arkansas, away from the outcrop area except where affected by large depressions. The direction of groundwater flow in 2009 is towards each of three large depressions. The first depression is located in western Cross and Poinsett Counties in the northern half of the study area, the second is in Arkansas, Jefferson, and Lincoln Counties in the center of the study area, and the third is in Union County in the southern part of the study area. Parts of the study area not affected by these three depressions exhibit a regional direction of groundwater flow to the east and south, away from the outcrop area. The highest waterlevel altitude measured in Sparta-Memphis aquifer was $325 \mathrm{ft}$ above NGVD 29, located in Grant County in the outcrop at the western boundary of the study area; the lowest water-level 
altitude was $157 \mathrm{ft}$ below NGVD 29 in Union County near the southern boundary of the study area. The water-level altitude in this well in Union County was $28 \mathrm{ft}$ higher than in 2005 (Schrader, 2006).

Eight depressions (represented by closed contours) are located in the following counties: Bradley; Ashley; Calhoun; Cleveland; Columbia; Arkansas, Jefferson, Lincoln, and Prairie; Cross and Poinsett; and Union. Depressions usually are caused by withdrawal rates that exceed recharge rates within the aquifer over an extended period of time. When a well is pumped, the water level in and around the well declines, creating a depression in the potentiometric surface. Groundwater flows toward the depression at a rate that is proportional to the slope of the depression and the transmissivity of the aquifer. If withdrawal rates exceed recharge rates to the aquifer, the area of the declining water level expands to form a depression.

Two large depressions, centered in Jefferson and Union Counties, are the result of large withdrawals for industrial, irrigation, or public supply. The depression centered in Jefferson County has deepened and expanded in recent years into Arkansas and Prairie Counties as a result of large withdrawals for irrigation and public supply. The lowest water-level altitude measured in this depression is approximately $3 \mathrm{ft}$ higher in 2009 than in 2007 (Schrader, 2009). The area enclosed within the 40 -ft contour on the 2009 potentiometric-surface map has expanded south to the Drew County line and moved west from the intersection of Arkansas, Jefferson, and Lincoln Counties when compared with the 2007 potentiometric-surface map (Schrader, 2009). To the north, east, and west, the location of the $40-\mathrm{ft}$ contour is comparable to the 2007 potentiometric-surface map (Schrader, 2009). The area of $40-\mathrm{ft}$ contour is about the same on the 2009 and 2007 potentiometric-surface maps (Schrader, 2009).

The depression in Union County is roughly circular within the $-60-\mathrm{ft}$ contour. The lowest water-level altitude measurement was $161 \mathrm{ft}$ below NGVD 29 in 2007 (Schrader, 2009), with a 4-ft rise to $157 \mathrm{ft}$ below NGVD 29 in 2009. In 2003, this depression was elongated east and west and beginning to coalesce with the depression in Columbia County (Schrader, 2006). Decreasing withdrawals in Columbia and Union Counties have resulted in a separation of these two depressions. The depression in Union County has diminished and encloses a smaller area than in recent years. The lowest water-level altitude measurement during 2009 in the center of the depression in Union County, represents a rise of $42 \mathrm{ft}$ since 2003 (Schrader, 2006). The location of the lowest water-level altitude can vary through time. Changes in pumping rates and well efficiency can affect the location of the lowest water-level altitude. The lowest water-level altitude measurement in 2009 is from a different well than the lowest water-level altitude measurement in 2003 (Schrader, 2006). The area enclosed by the lowest altitude contour, $140 \mathrm{ft}$ below NGVD 29, on the 2009 potentiometric-surface map is about half the area enclosed by that same contour on the 2007 potentiometric-surface map (Schrader, 2009). On the 2007 potentiometric-surface map (Schrader, 2009), the lowest altitude contour, $160 \mathrm{ft}$ below NGVD 29, is not present on the 2009 potentiometric-surface map. Since 2001, the depression in Union County has receded from Union Parish, Louisiana. The -100-ft contour had extended into Union Parish on the 2001 potentiometric-surface map (Schrader, 2004). The $-60-\mathrm{ft}$ contour on the 2009 potentiometric-surface map is near the Arkansas-Louisiana State border. A broad depression in western Poinsett and Cross Counties was first shown in the 1995 potentiometric-surface map (Stanton, 1997) and has both increased and decreased in size since 1995. The depression expanded in area in 1997 and 1999 and then decreased in area in 2003 and 2005. In 1997, the depression covered most of the western half of Poinsett County (Joseph, 1998). In 1999, the 150-ft contour of the depression extended from Poinsett County through Cross County into St. Francis County (Joseph, 2000; Schrader, 2004). In 2003, the depression covered most of the western half of Poinsett County (Schrader, 2006). In 2005, the depression covered part of western Poinsett County and extended into northwestern Cross County. In 2007, the 140-ft contour expanded north to the Poinsett-Craighead County line, further east, and the farthest extent south into Cross County (Schrader and Jones, 2007). In 2009, the 140-ft contour has extended south across Cross County about two-thirds of the distance to the St. Francis County line. The lowest water-level altitude measurement in this depression, $131 \mathrm{ft}$ above NGVD 29, is 3 $\mathrm{ft}$ lower than in 2007.

Unlike other depressions in the Sparta-Memphis aquifer, the depression in Poinsett and Cross Counties primarily is caused by withdrawals for irrigation, instead of withdrawals for public supply and industrial uses. The Mississippi Embayment Regional Aquifer Study project has identified an area in Poinsett and Cross Counties where the Sparta-Memphis aquifer and the Mississippi River Valley alluvial aquifer (herein referred to as the alluvial aquifer) are hydrologically connected. Borehole geophysical logs show that the Jackson Group, the unit that underlies the alluvial aquifer; the Cockfield Formation of Claiborne Group; and the Cook Mountain Formation of Claiborne Group, the unit that confines the Sparta-Memphis aquifer, are absent in this area (Hart and others, 2008). Irrigation withdrawals from the alluvial aquifer have resulted in water-level declines in the Sparta-Memphis aquifer (Schrader, 2008). 
Five other depressions are shown on the 2009 potentiometric surface. The depression in Columbia County was first shown on the 1996-97 potentiometric-surface map (Joseph, 1998). In 2009, the area has decreased, with water levels rising about $3 \mathrm{ft}$ since 2005 in the well with the lowest water-level altitude measurement. The depression in Calhoun County was first shown on the 1999 potentiometric-surface map (Joseph, 2000). The area and depth remained reasonably consistent from 2001 to 2005 (Schrader, 2004, 2006; Schrader and Jones, 2007), but the depression expanded and deepened in 2007 (Schrader, 2009). In 2009, the area and depth are about the same as in 2007. The depressions in Bradley and Ashley Counties were first shown in 2007 (Schrader, 2009). In 2009, this depression has separated into two small depressions in Bradley and Ashley Counties. The depression in Cleveland County was first shown in 2003 (Schrader, 2006). This depression has deepened from 24 to $17 \mathrm{ft}$ above NGVD 29 from 2003 to 2009.

\section{Water-Level Difference from 2005 to 2009}

A water-level difference map (pl. 2) was constructed using the difference between water-level measurements made during 2005 and 2009 at 309 wells (appendix 2). The difference in water levels was calculated by subtracting the 2009 depth-to-water level from the 2005 depth-to-water level. Negative values shown on plate 2 indicate a decline and positive values indicate a rise in water level. Rises in water level are indicated on plate 2 with blue triangles pointing upward; declines in water level are indicated with red triangles pointing downward. Triangles are scaled to the relative value of the rise or decline. Water-level differences do not necessarily indicate a long-term water-level trend, but are intended to show where water levels have increased or decreased from 2005 to 2009.

The differences in water level between 2005 and 2009 ranged from -74.6 to $60.2 \mathrm{ft}$, with a mean of $-1.1 \mathrm{ft}$. The largest measured rise $(60.2 \mathrm{ft})$ in water level was in Union County. The largest measured decline (-74.6 ft) in water level was in Columbia County. Areas with a general rise in water levels include central Columbia County, southern Jefferson County, and most of Union County (pl. 2). The inset map on plate 2 shows a more detailed view of part of Union County. In the area around west-central Union County (pl. 2), water levels in 18 wells rose $20 \mathrm{ft}$ or more, with an average annual rise of $5 \mathrm{ft}$ or more. The rising water levels in west-central Union County coincide with water conservation measures initiated in 1999 and the conversion of large industrial water users from groundwater to surface water from the Ouachita River beginning in December 2004 (Freiwald and Johnson, 2008). Water levels generally declined throughout most of the Sparta-Memphis aquifer.

\section{Long-Term Hydrographs}

Hydrographs from 206 wells with a minimum of 25 years of water-level measurements were constructed. Selected hydrographs are shown in figure 4 with locations indicated on plate 1. The well 04S05W05ACC1 in Arkansas County has only 3 years of continuous data and has been included for additional discussion. The data for well 04S05W05ACC1 has not been included in the statistical summary for Arkansas County. The minimum 25-year period of record is used to evaluate long-term trends not dominated by variations in climate and localized pumping rates on water levels in a single well. A trend line using linear regression was calculated for the period from 1985 to 2009 to determine the slope in feet per year ( $\mathrm{ft} / \mathrm{yr}$ ) for water levels in each well. The slope of the trend line represents the typical annual decline or rise in water level during the 25-year period. A statistical summary of the number of wells, the range, mean, and median of the annual rise or decline in water level, and the range of the $\mathrm{R}^{2}$ values for each county is listed in table 2 . Negative values denote a decline in water level.

During the period 1985-2009, county mean annual water levels generally declined. The county mean annual water level rose in Calhoun, Columbia, Lafayette, and Union Counties (table 2) about $1.3 \mathrm{ft} / \mathrm{yr}, 0.2 \mathrm{ft} / \mathrm{yr}, 0.1 \mathrm{ft} /$ $\mathrm{yr}$, and $0.6 \mathrm{ft} / \mathrm{yr}$, respectively. In Union County, 2009 is the first year that the county mean has shown a rise since the county hydrograph analysis of water-level rise or decline was first used in 1996-97 (Joseph, 1998). Mean annual declines were between $0.5 \mathrm{ft} / \mathrm{yr}$ and $0.0 \mathrm{ft} / \mathrm{yr}$ in Ashley, Cleveland, Crittenden, Dallas, Grant, Monroe, Nevada, Ouachita, Phillips, St. Francis, and Woodruff Counties. Mean annual declines were between $1.0 \mathrm{ft} / \mathrm{yr}$ and $0.5 \mathrm{ft} / \mathrm{yr}$ in Craighead, Desha, Drew, Lonoke, Mississippi, and Pulaski Counties. Mean annual declines were between $1.5 \mathrm{ft} / \mathrm{yr}$ and $1.0 \mathrm{ft} / \mathrm{yr}$ in Arkansas, Bradley, Cross, Jefferson, Lee, Poinsett, and Prairie Counties. The mean annual decline for Lincoln County was $2.3 \mathrm{ft} / \mathrm{yr}$. The data set for Lincoln County wells was skewed by a single well having an annual decline of $4.6 \mathrm{ft} / \mathrm{yr}$. The median annual decline for Lincoln County was about $1.6 \mathrm{ft} / \mathrm{yr}$.

Water levels in the Sparta-Memphis aquifer may change substantially throughout the year. In western Arkansas County, hydrograph B (pl. 1, fig. 4) shows 3 years of daily water levels. In September 2006, a transducer was installed at this site to collect hourly water levels. These data are transmitted four times a day for display on the USGS water data Web site (http://waterdata.usgs.gov). The hydrograph shows about a 60 -ft seasonal change in water level for both years shown. The period of the $60-\mathrm{ft}$ decline in water level coincides with the spring-summer irrigation season. 


\section{Water-Quality Conditions}

Water samples were collected in the summer of 2009 from 64 wells completed in the Sparta-Memphis aquifer and measured onsite for specific conductance, temperature, and $\mathrm{pH}$ (appendix 3). Although there is a regional increase in specific conductance to the east and south, anomalous increases occur in some parts of the study area. Specific conductance ranged from 43 microsiemens per centimeter at 25 degrees Celsius $(\mu \mathrm{S} / \mathrm{cm})$ in Ouachita County to $1,230 \mu \mathrm{S} / \mathrm{cm}$ in Phillips County. Relatively large specific conductance values (greater than $700 \mu \mathrm{S} / \mathrm{cm}$ ) occur in samples from wells in Arkansas, Ashley, Monroe, Phillips, and Union Counties. Morris and Bush (1986) and Broom and others (1984) cited upward leakage of saltwater from the Nacatoch Formation of Cretaceous age into the Sparta aquifer through a fault or abandoned oil and gas wells as possible explanations for these anomalies. Large specific conductance values occur near the water-level depression (pl. 1) in Union County and increase eastward toward Ashley County. This increase in specific conductance may be because of leakage of water with greater conductance from an underlying aquifer. Several specific-conductance values greater than $2,000 \mu \mathrm{S} / \mathrm{cm}$ for groundwater from the Sparta aquifer in Union County have been documented (Broom and others, 1984).

Specific conductance values from samples collected in 2009 and 2005 generally were less than $400 \mu \mathrm{S} / \mathrm{cm}$. The histograms of specific conductance data for 2009 (64 samples), and 2005 (60 samples) are shown in figure 5 (Schrader, 2007). The mean specific conductance was $392 \mu \mathrm{S} / \mathrm{cm}$ in 2009 and $362 \mu \mathrm{S} / \mathrm{cm}$ in 2005. Both histograms have a right skew. The largest category for both years is the $201-400 \mu \mathrm{S} / \mathrm{cm}$ range. The $201-400 \mu \mathrm{S} / \mathrm{cm}$ range included 53 percent of the samples in 2009 and 38 percent of the samples in 2005. The lowest range, 1-200 $\mu \mathrm{S} / \mathrm{cm}$, decreased from 33 percent of the samples in 2005 to 14 percent of the samples in 2009. The small change in the mean specific conductance and the distribution of data from 2005 to 2009 may indicate a change in water quality or be the result of the distribution of sampling locations. 
A. ARKANSAS COUNTY, WELL 03S06W30BBD1
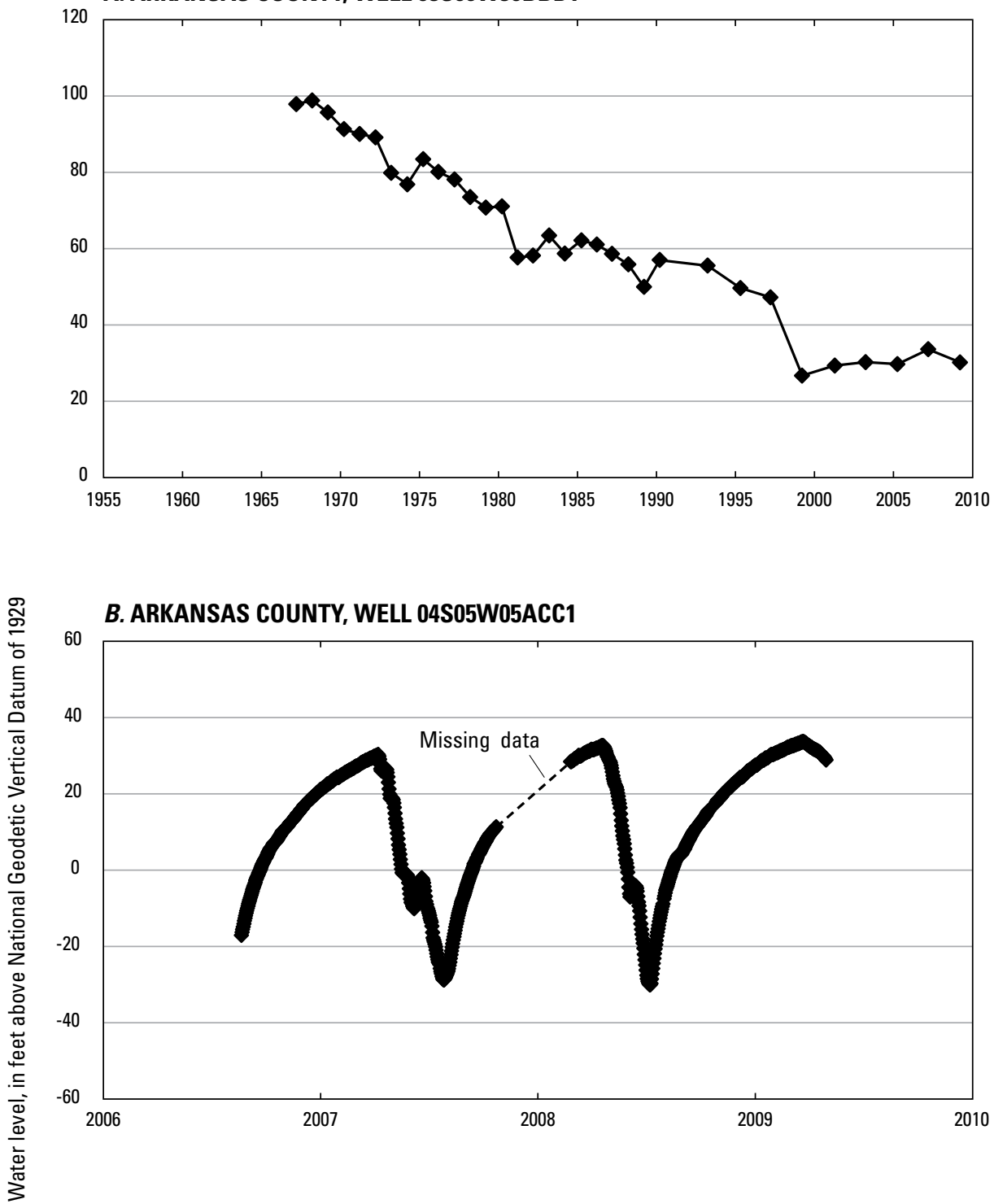

C. ARKANSAS COUNTY, WELL 07S03W06ABC1

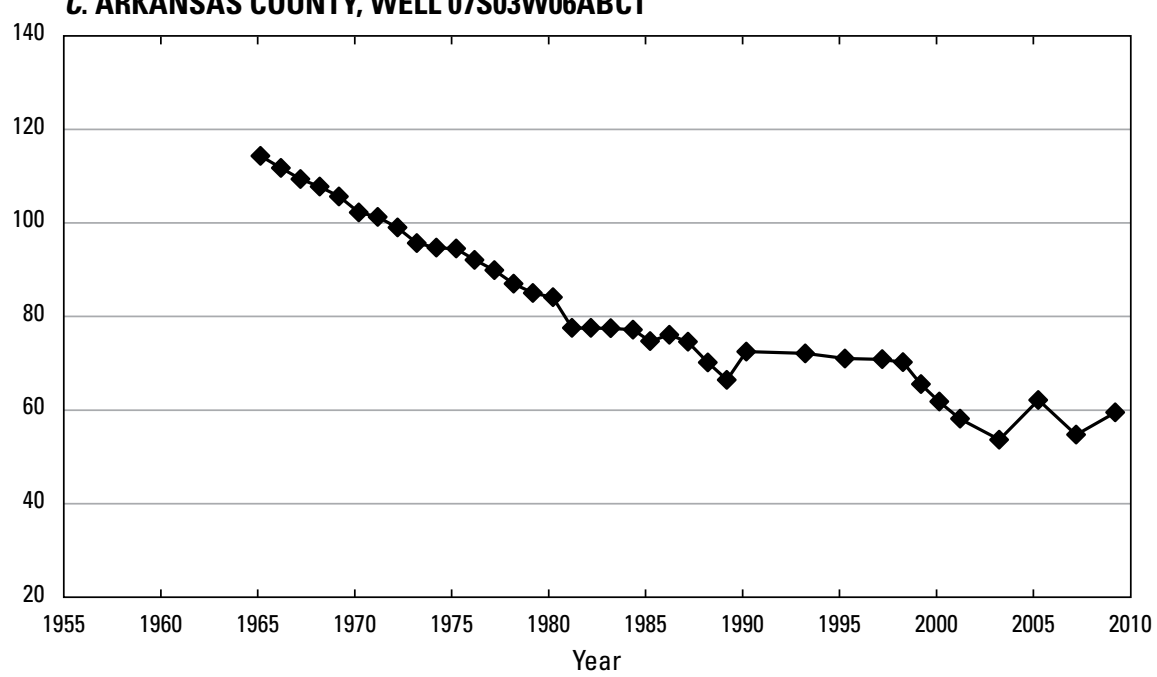

Figure 4. Water-level hydrographs for selected wells completed in the Sparta-Memphis aquifer in Arkansas. 

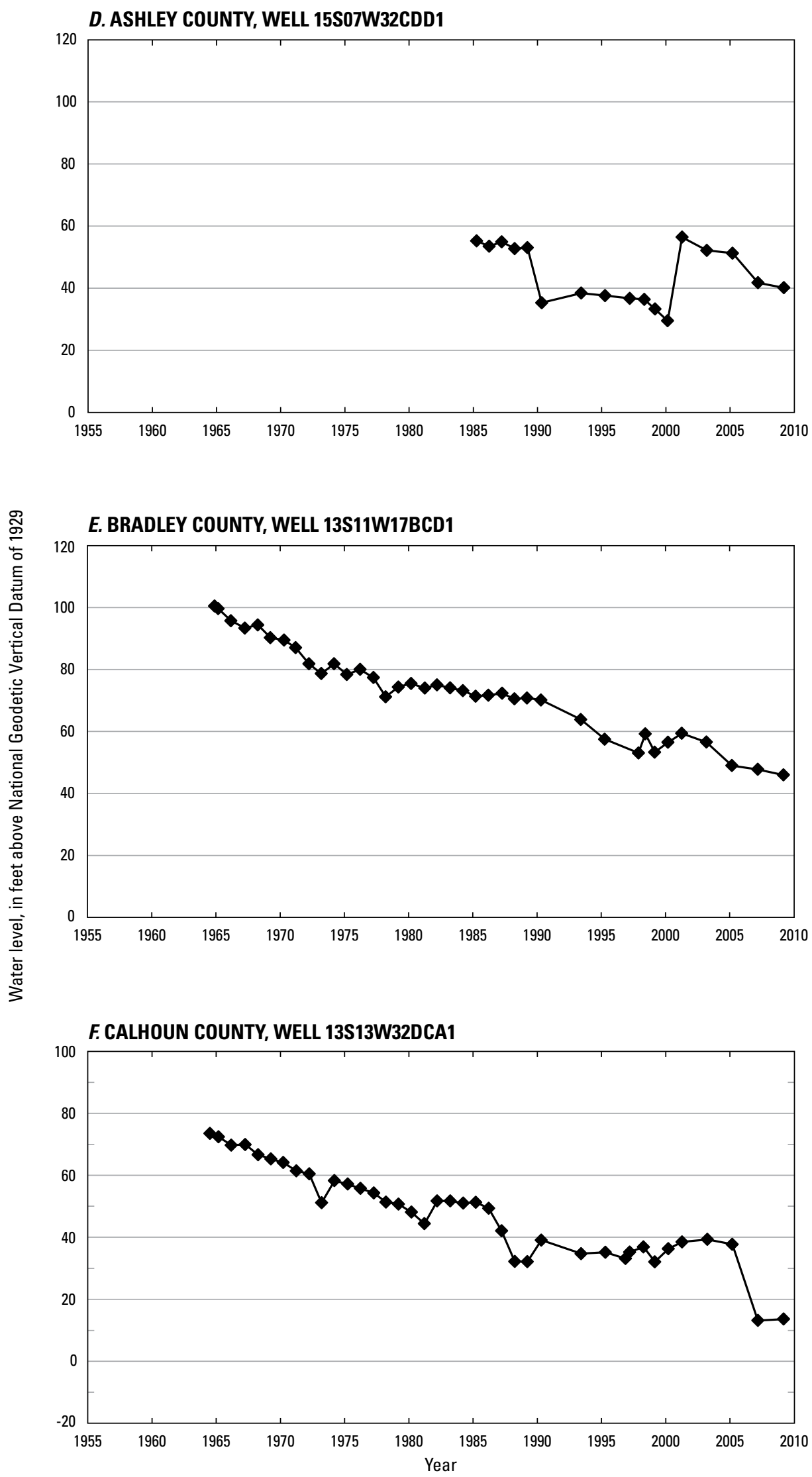

Figure 4. Water-level hydrographs for selected wells completed in the Sparta-Memphis aquifer in Arkansas.-Continued 


\section{G. CLEVELAND COUNTY, WELL 10S12W12BDD1}
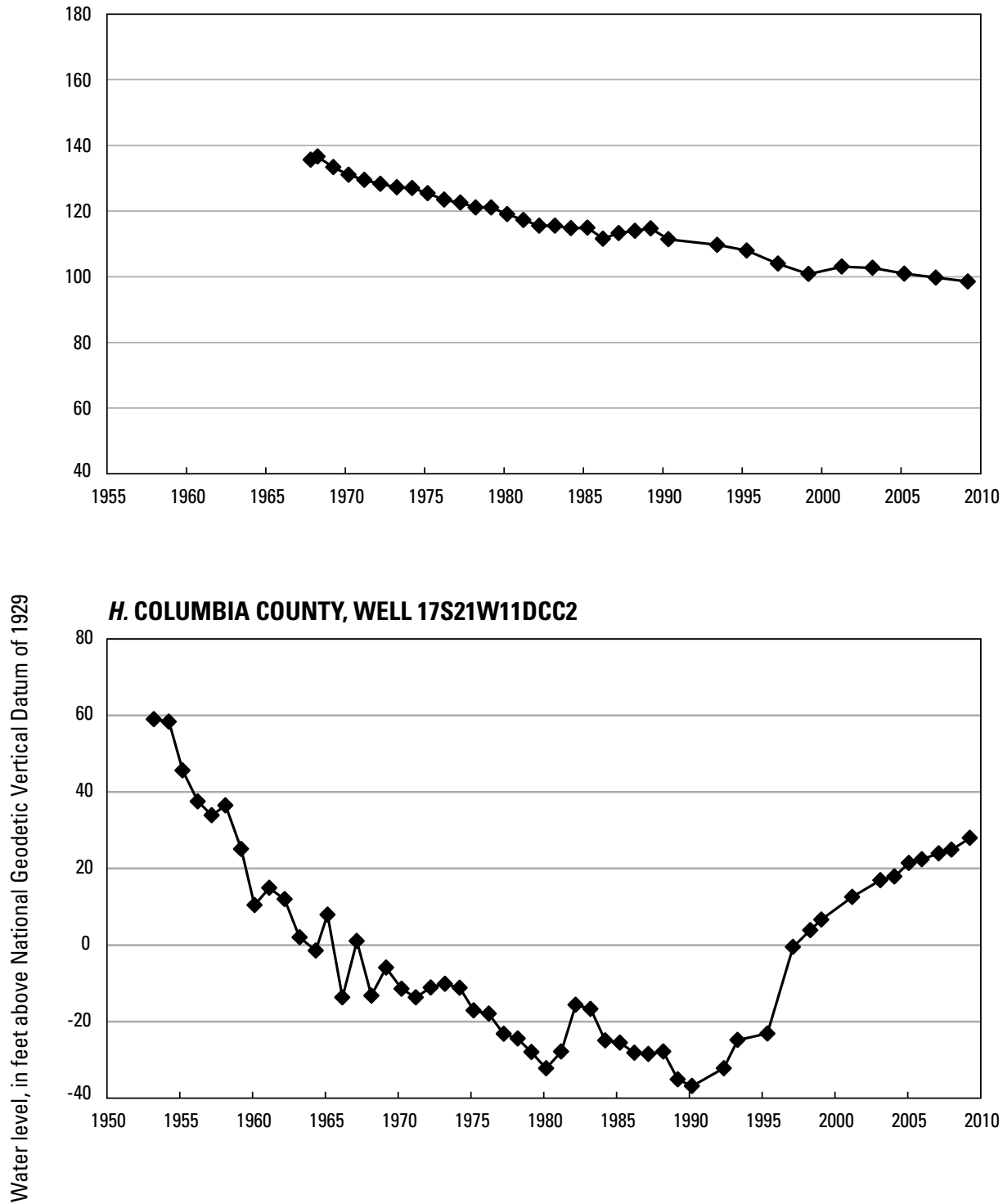

I. CRAIGHEAD COUNTY, WELL 14N04E22CBD1

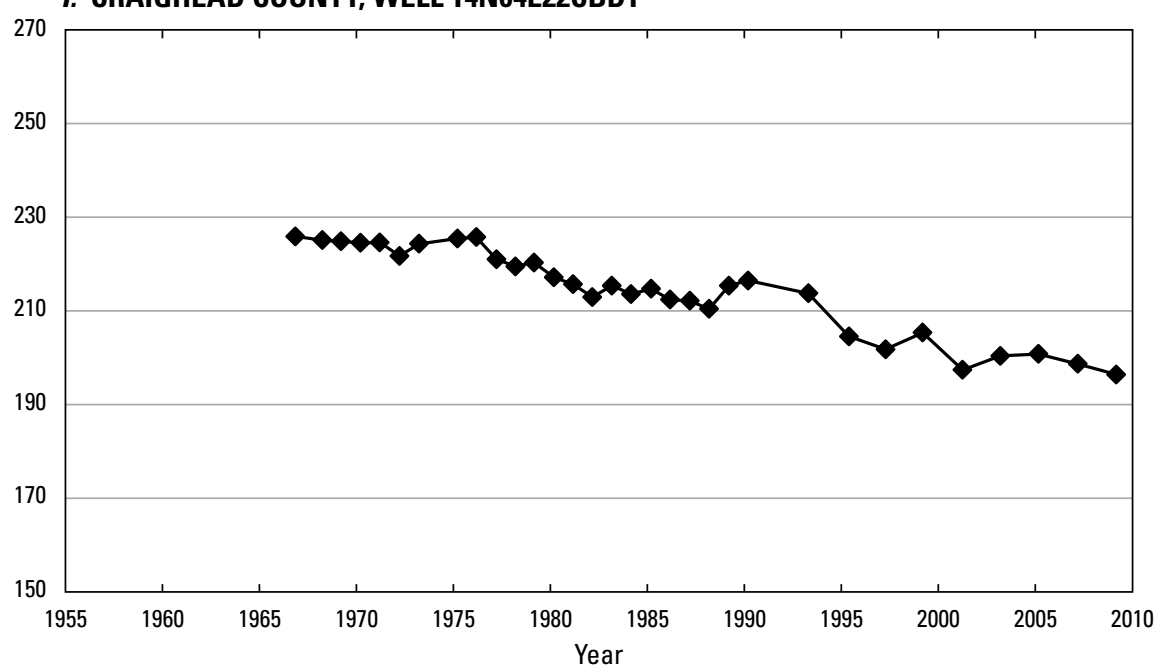

Figure 4. Water-level hydrographs for selected wells completed in the Sparta-Memphis aquifer in Arkansas.-Continued 


\section{J. CRITTENDEN COUNTY, WELL 06N07E01DAD2}
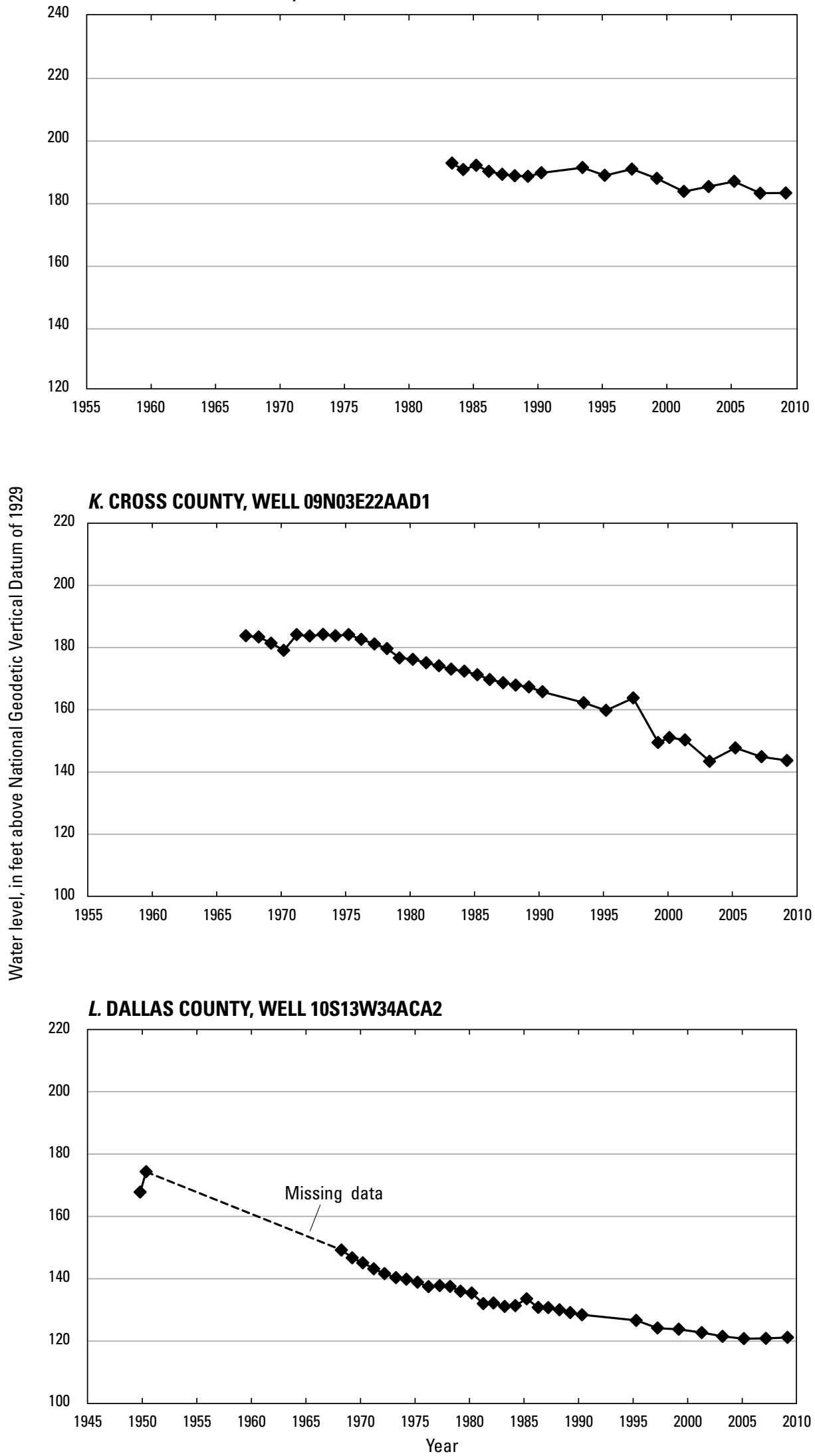

Figure 4. Water-level hydrographs for selected wells completed in the Sparta-Memphis aquifer in Arkansas.-Continued 

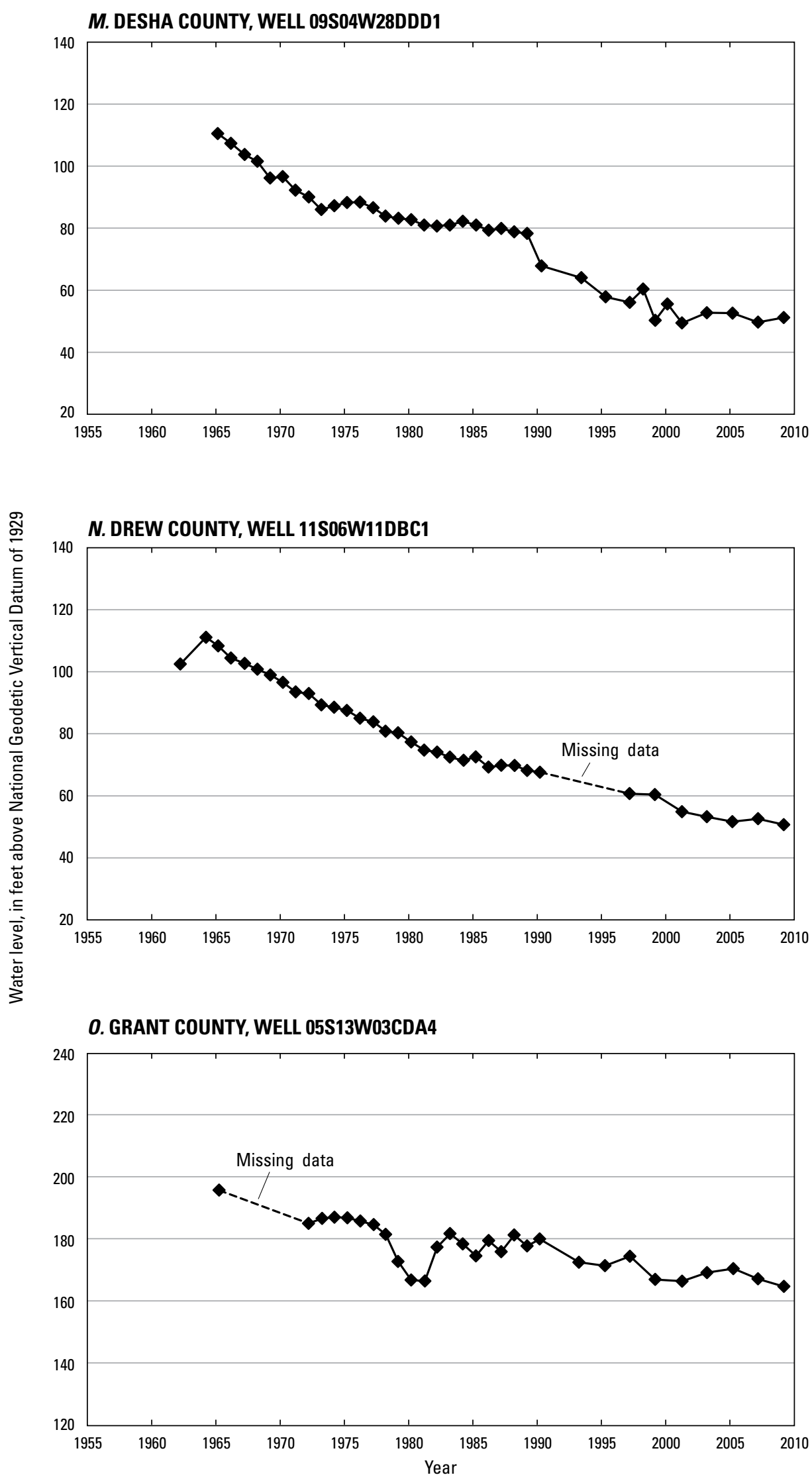

Figure 4. Water-level hydrographs for selected wells completed in the Sparta-Memphis aquifer in Arkansas.—Continued 


\section{P. JEFFERSON COUNTY, WELL 06S08W16CCC1}
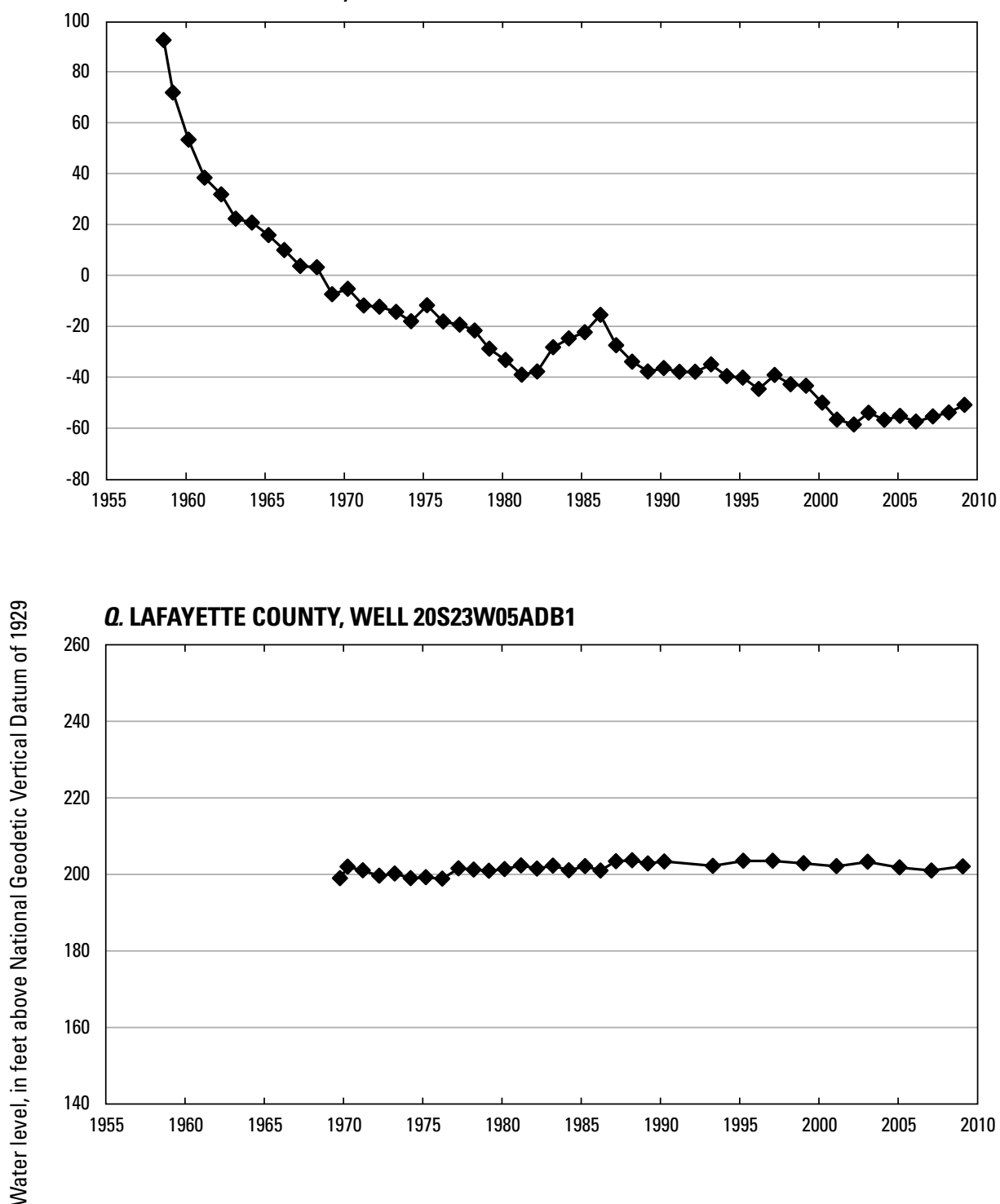

R. LEE COUNTY, WELL 03N03E28CDB1

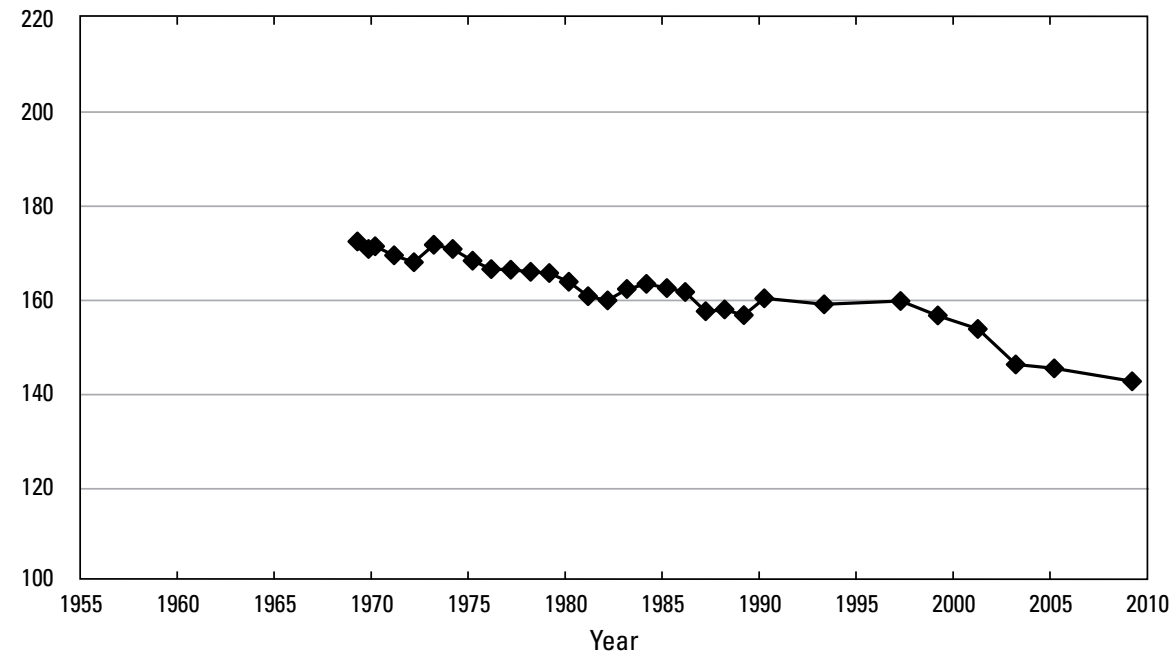

Figure 4. Water-level hydrographs for selected wells completed in the Sparta-Memphis aquifer in Arkansas.-Continued 


\section{S. LINCOLN COUNTY, WELL 08S05W03BAA2}
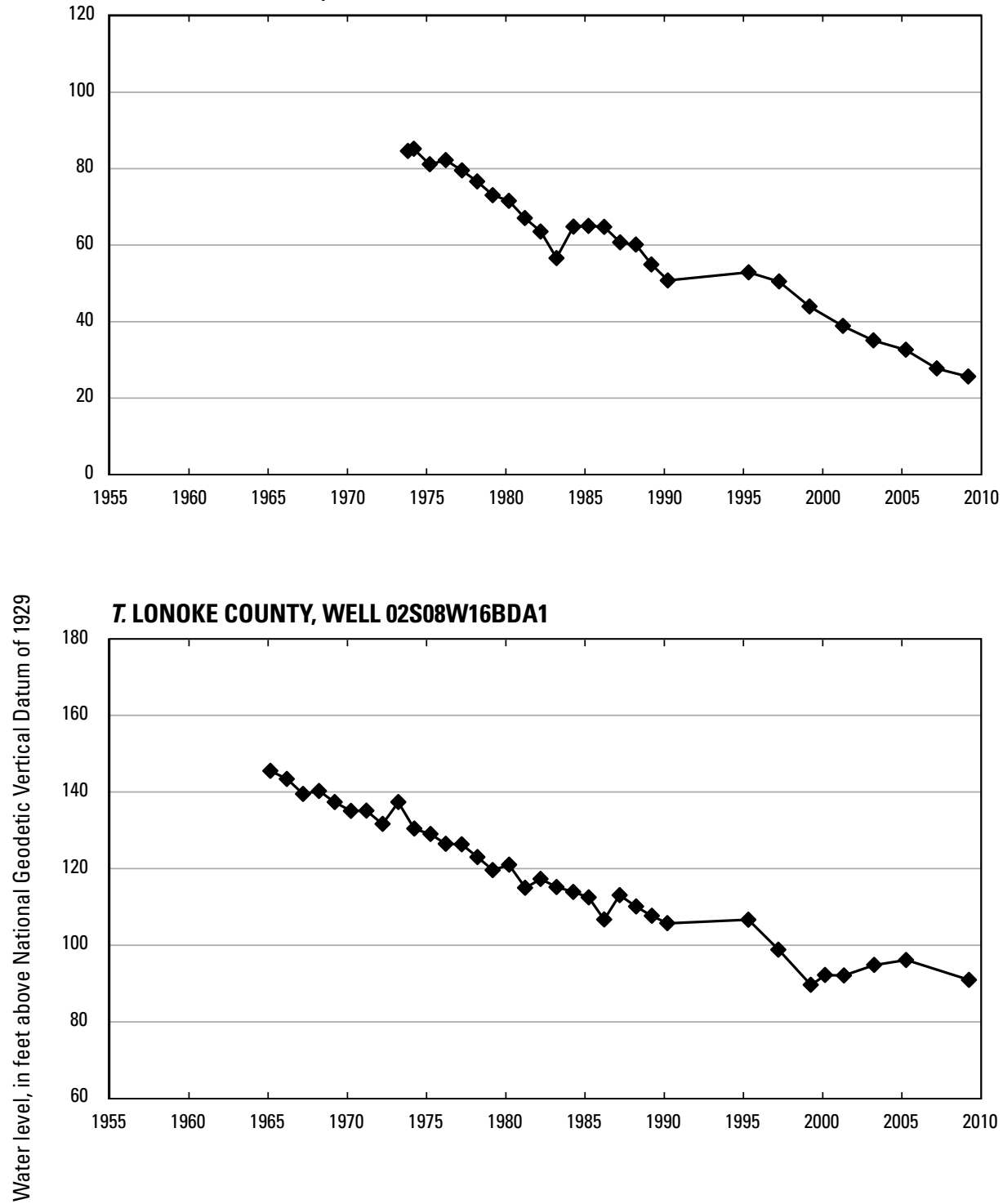

U. MONROE COUNTY, WELL 04N02W28DDD4

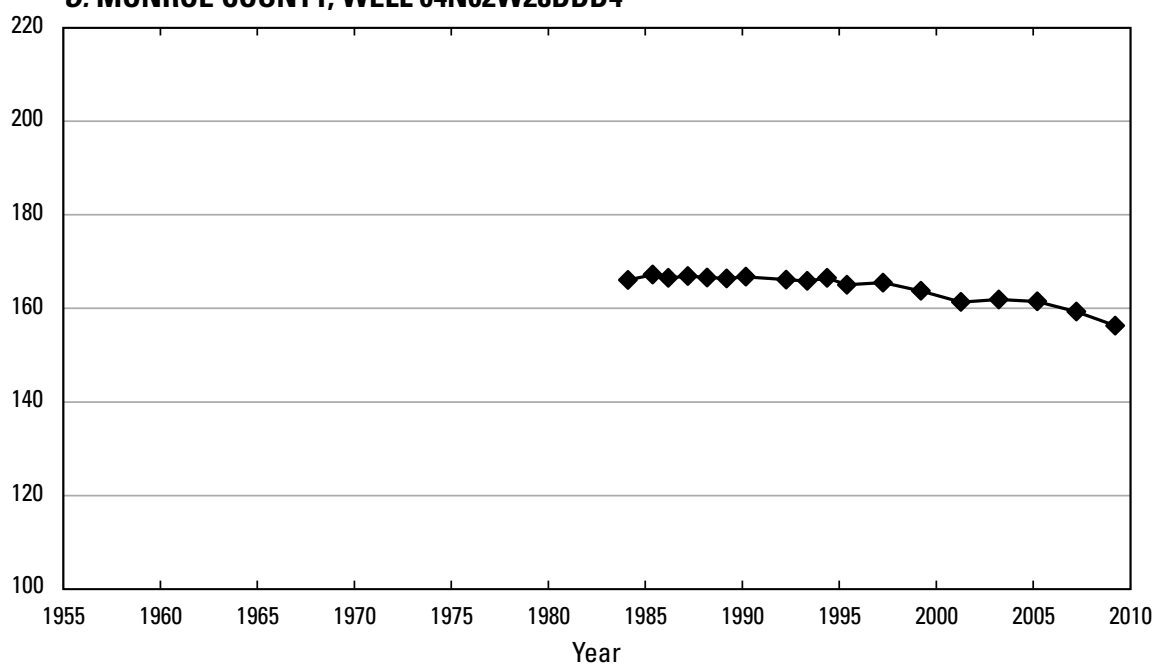

Figure 4. Water-level hydrographs for selected wells completed in the Sparta-Memphis aquifer in Arkansas.—Continued 
V. OUACHITA COUNTY, WELL 14S17W05CAD1
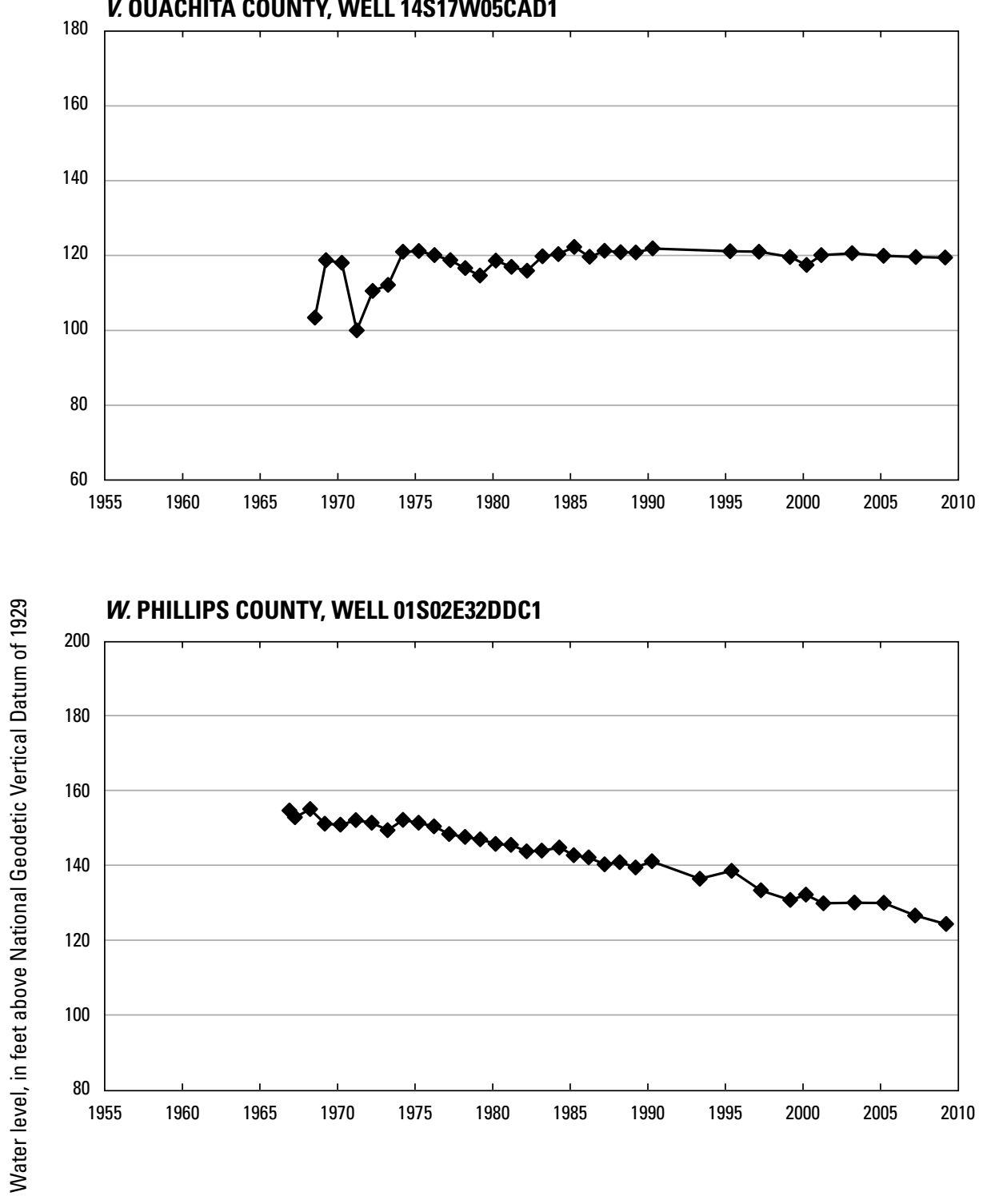

X. POINSETT COUNTY, WELL 10N01E15DBB1

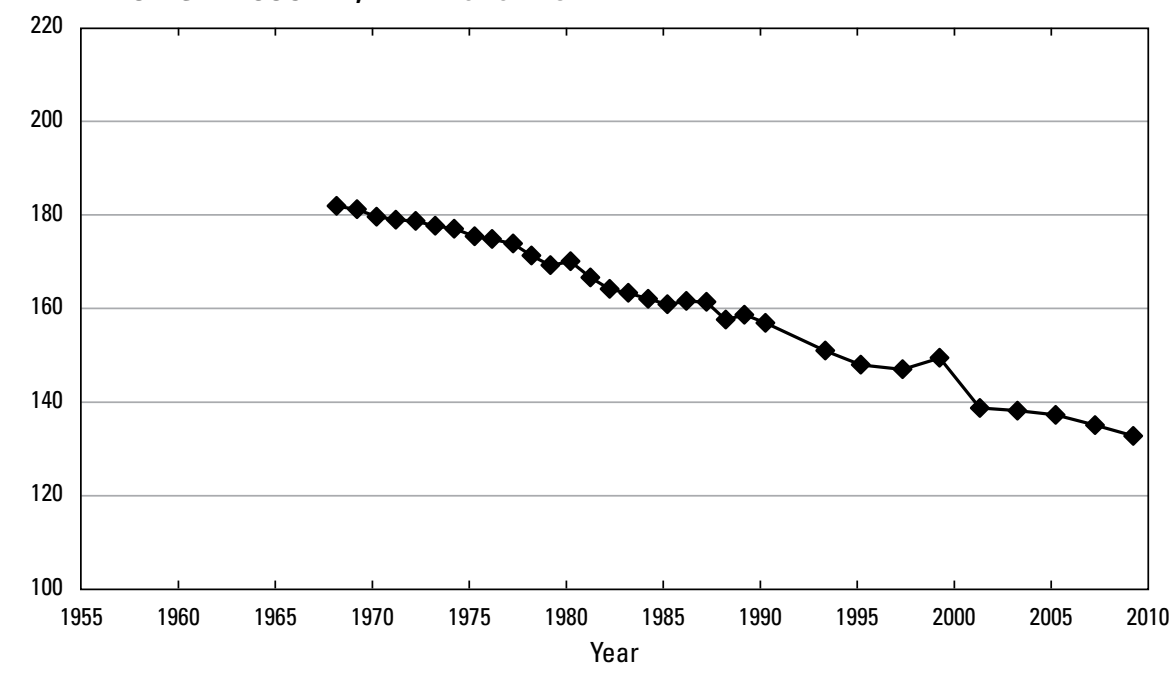

Figure 4. Water-level hydrographs for selected wells completed in the Sparta-Memphis aquifer in Arkansas.-Continued 

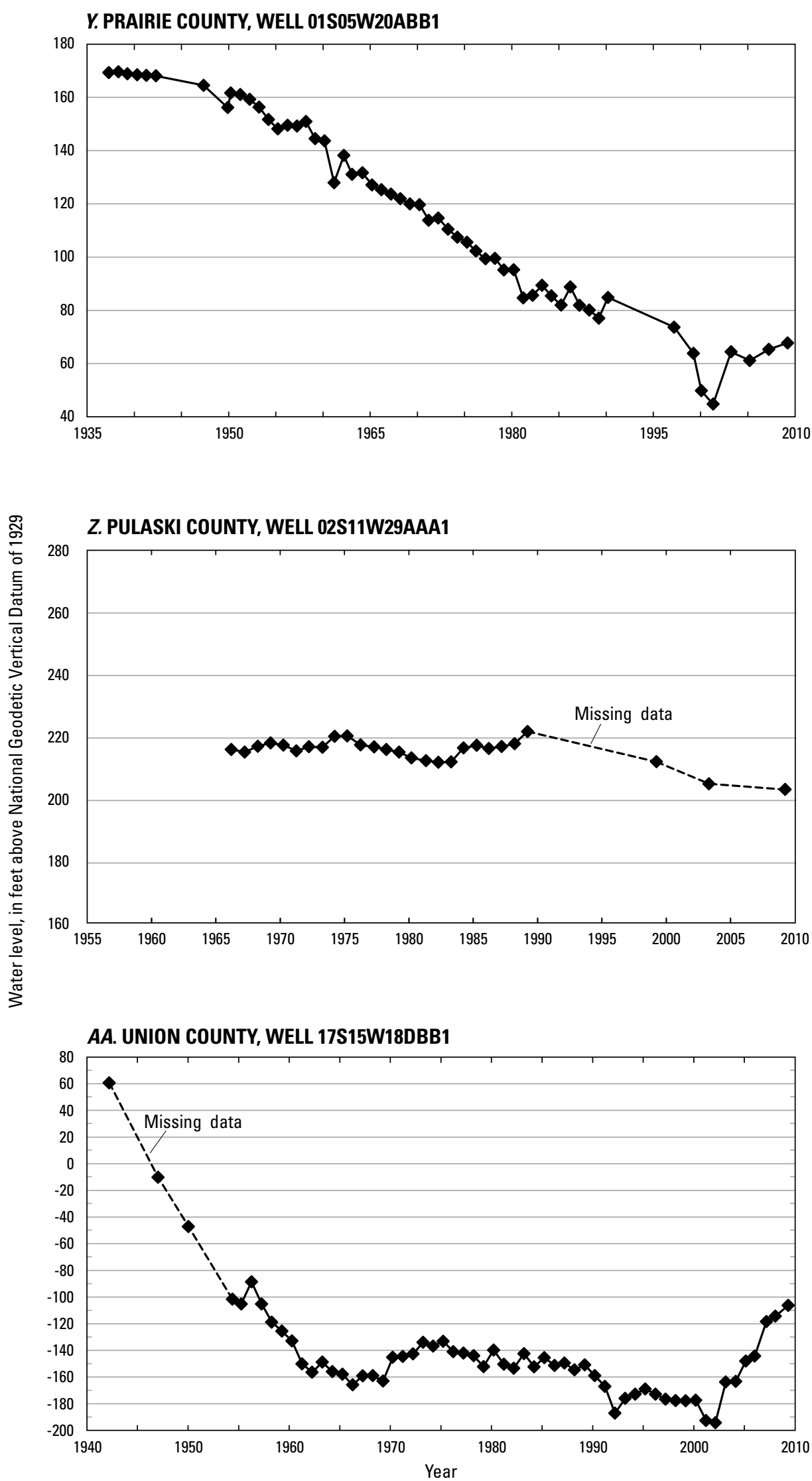

Figure 4. Water-level hydrographs for selected wells completed in the Sparta-Memphis aquifer in Arkansas.—Continued 
AB. UNION COUNTY, WELL 19S16W35DDC1

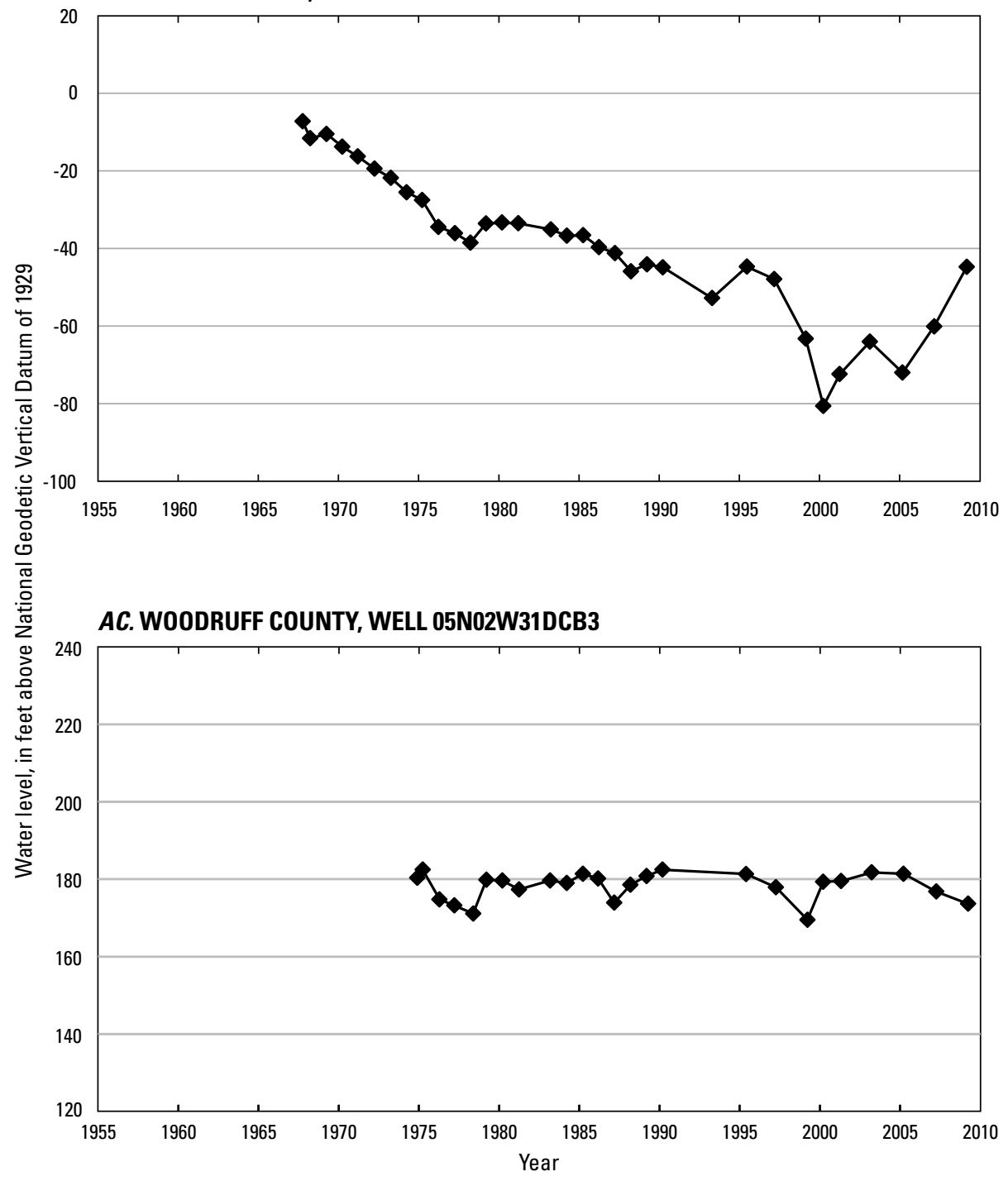

Figure 4. Water-level hydrographs for selected wells completed in the Sparta-Memphis aquifer in Arkansas.—Continued 
Table 2. Number of wells, range, mean, median, and correlation coefficient, $\mathrm{R}^{2}$, of annual rise-decline in water level by county for wells in the Sparta-Memphis aquifer, 1985-2009.

[Annual rise or decline in water level for each well is calculated using linear regression; negative value indicates decline; positive value indicates rise]

\begin{tabular}{|c|c|c|c|c|c|}
\hline County & $\begin{array}{l}\text { Number } \\
\text { of wells }\end{array}$ & $\begin{array}{l}\text { Range of annual rise- } \\
\text { decline in water level } \\
\text { (feet/year) }\end{array}$ & $\begin{array}{c}\text { Mean annual rise- } \\
\text { decline in water level } \\
\text { (feet/year) }\end{array}$ & $\begin{array}{l}\text { Median annual rise- } \\
\text { decline in water level } \\
\text { (feet/year) }\end{array}$ & $\begin{array}{l}\text { Range of } R^{2} \text { values } \\
\text { for trend line }\end{array}$ \\
\hline Arkansas & 27 & -1.97 to 0.47 & -1.07 & -1.28 & 0.01 to 0.84 \\
\hline Ashley & 1 & -0.40 to -0.40 & -0.40 & -0.40 & 0.11 to 0.11 \\
\hline Bradley & 3 & -1.46 to -0.77 & -1.11 & -1.13 & 0.67 to 0.97 \\
\hline Calhoun & 3 & -0.88 to 5.48 & 1.25 & -0.84 & 0.46 to 0.78 \\
\hline Cleveland & 6 & -1.50 to 1.06 & -0.45 & -0.60 & 0.24 to 0.92 \\
\hline Columbia & 14 & -0.77 to 2.89 & 0.24 & -0.04 & 0.04 to 0.94 \\
\hline Craighead & 3 & -0.80 to -0.40 & -0.67 & -0.80 & 0.13 to 0.82 \\
\hline Crittenden & 4 & -0.29 to 0.11 & -0.09 & -0.10 & 0.00 to 0.67 \\
\hline Cross & 4 & -1.24 to -0.84 & -1.01 & -0.99 & 0.77 to 0.93 \\
\hline Dallas & 10 & -0.58 to -0.02 & -0.24 & -0.16 & 0.01 to 0.96 \\
\hline Desha & 6 & -1.50 to -0.69 & -0.96 & -0.75 & 0.37 to 0.92 \\
\hline Drew & 5 & -0.95 to -0.15 & -0.59 & -0.51 & 0.02 to 0.99 \\
\hline Grant & 8 & -1.53 to -0.07 & -0.48 & -0.37 & 0.18 to 0.95 \\
\hline Jefferson & 18 & -2.67 to 0.00 & -1.30 & -1.26 & 0.00 to 0.94 \\
\hline Lafayette & 3 & -0.03 to 0.15 & 0.05 & 0.02 & 0.00 to 0.40 \\
\hline Lee & 2 & -1.53 to -0.69 & -1.11 & -1.11 & 0.75 to 0.98 \\
\hline Lincoln & 6 & -4.60 to -1.28 & -2.30 & -1.63 & 0.58 to 0.98 \\
\hline Lonoke & 3 & -1.21 to -0.77 & -0.99 & -0.99 & 0.71 to 0.99 \\
\hline Mississippi & 1 & -0.55 to -0.55 & -0.55 & -0.55 & 0.28 to 0.28 \\
\hline Monroe & 4 & -1.02 to 0.07 & -0.37 & -0.27 & 0.00 to 0.94 \\
\hline Nevada & 1 & -0.18 to -0.18 & -0.18 & -0.18 & 0.10 to 0.10 \\
\hline Ouachita & 15 & -1.42 to 0.95 & -0.12 & -0.07 & 0.00 to 0.93 \\
\hline Phillips & 6 & -0.73 to 0.37 & -0.26 & -0.24 & 0.00 to 0.95 \\
\hline Poinsett & 2 & -1.28 to -0.77 & -1.02 & -1.02 & 0.48 to 0.97 \\
\hline Prairie & 10 & -1.50 to 0.22 & -1.12 & -1.22 & 0.03 to 0.96 \\
\hline Pulaski & 1 & -0.66 to -0.66 & -0.66 & -0.66 & 0.85 to 0.85 \\
\hline St. Francis & 1 & -0.15 to -0.15 & -0.15 & -0.15 & 0.09 to 0.09 \\
\hline Union & 38 & -1.21 to 9.20 & 0.64 & -0.35 & 0.01 to 0.99 \\
\hline Woodruff & 1 & -0.11 to -0.11 & -0.11 & -0.11 & 0.06 to 0.06 \\
\hline
\end{tabular}




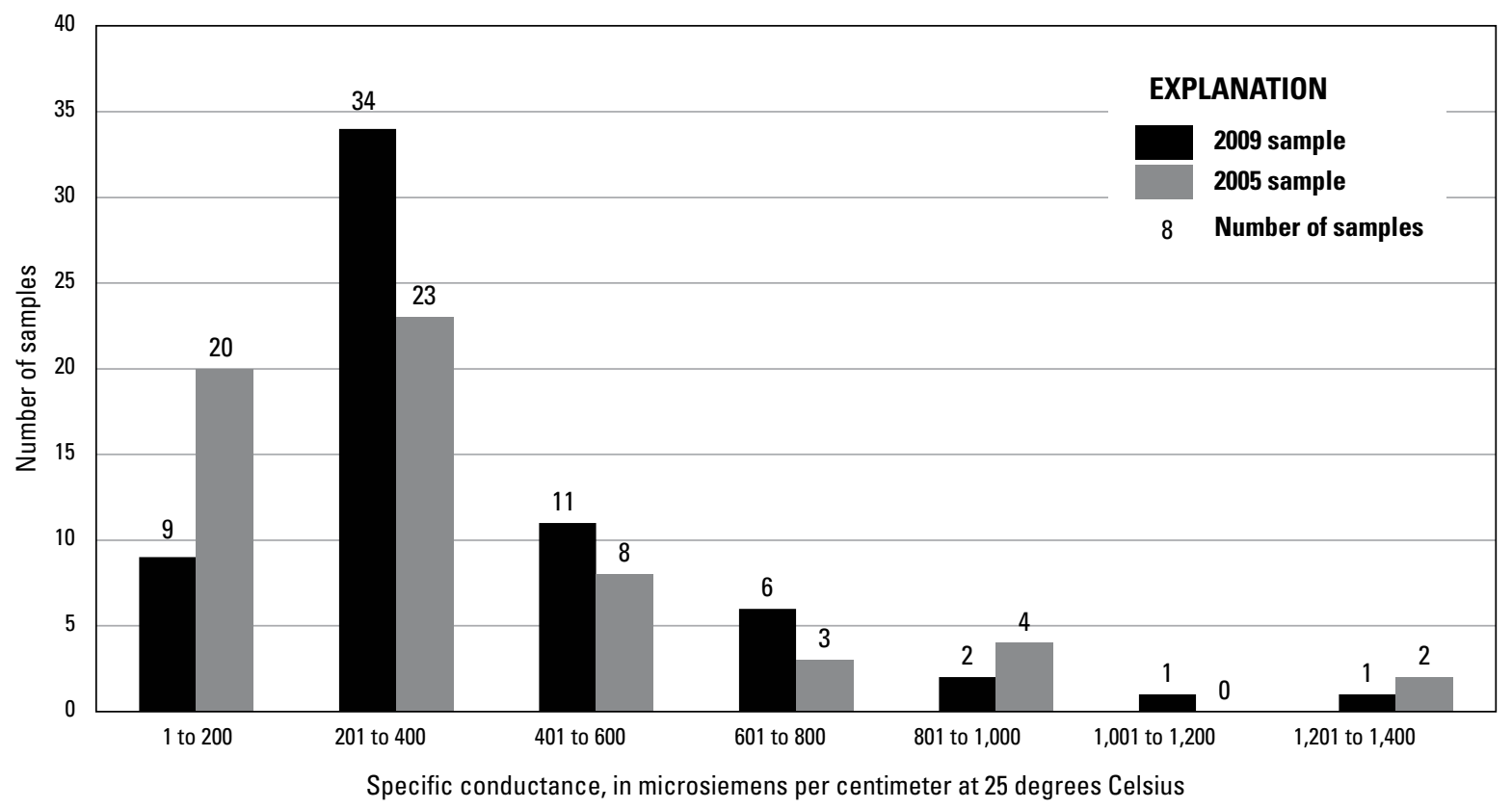

Figure 5. Distribution of specific conductance in samples from the Sparta-Memphis aquifer in 2005 and 2009 in Arkansas.

\section{Summary}

The U.S. Geological Survey in cooperation with the Arkansas Natural Resources Commission and the Arkansas Geological Survey has monitored water levels since the 1920's. Groundwater withdrawals generally have increased while water levels generally have declined since monitoring was initiated. During the spring of 2009, 324 water levels were measured in wells completed in the Sparta-Memphis aquifer. During the summer of 2009, 64 water-quality samples were collected and measured for specific conductance, temperature, and $\mathrm{pH}$ from wells completed in the SpartaMemphis aquifer.

Water use in the Sparta-Memphis aquifer in Arkansas generally increased from 1965 to 2000. In 2000, water use in the Sparta-Memphis aquifer was about $287 \mathrm{Mgal} / \mathrm{d}$, an increase of about 156 percent from 1965. In 2005, water use in the Sparta-Memphis aquifer declined to about $170 \mathrm{Mgal} / \mathrm{d}$.

The Sparta Sand is composed of a sequence of alternating sand and clay beds between the massive clays of the overlying Cook Mountain Formation of Claiborne Group and the underlying Cane River Formation of Claiborne Group confining units. The Sparta Sand is in the southern part of the study area (south of about 35 degrees latitude). The Memphis Sand is in the northern part of the study area (north of about 35 degrees latitude). The Memphis Sand is underlain by a thick layer of clay in the upper part of the Wilcox Group.

The regional direction of groundwater flow in the SpartaMemphis aquifer is generally to the south-southeast in the northern half of Arkansas and to the east and south in the southern half of Arkansas, away from the outcrop area except where affected by large depressions. The highest water-level altitude measured in the Sparta-Memphis aquifer was $325 \mathrm{ft}$ above the National Geodetic Vertical Datum of 1929 [NGVD 29] in the outcrop at the western boundary of the study area in Grant County; the lowest water-level altitude was $157 \mathrm{ft}$ below NGVD 29 in Union County.

Eight depressions are located in the study area. Two large depressions, centered in Jefferson and Union Counties, are the result of large withdrawals for industrial, irrigation, or public supply. The depression centered in Jefferson County has deepened and expanded in recent years into Arkansas and Prairie Counties as a result of large withdrawals for irrigation and public supply. The area enclosed within the 40 -foot contour on the 2009 potentiometric-surface map has expanded south to the Drew County line and moved west from the intersection of Arkansas, Jefferson, and Lincoln Counties since 2007. The lowest water-level altitude measurement during 2009 in the center of the depression in Union County has risen 42 feet since 2003. The area enclosed by the lowest altitude contour, 140 feet below NGVD 29, on the 2009 potentiometric-surface map is about half the area on the 2007 potentiometric-surface map. A broad depression in western Poinsett and Cross Counties was first shown in the 1995 potentiometric-surface map and is caused by withdrawals for irrigation. In the 2009 potentiometric-surface map, the $140-\mathrm{ft}$ contour extended north to the Poinsett-Craighead County line and south across Cross County about two-thirds of the distance to the St. Francis County line.

A water-level difference map was constructed using the difference between water-level measurements made during 2005 and 2009 from 309 wells. The difference in water level 
between 2005 and 2009 ranged from -74.6 to 60.2 feet. Areas with a general rise in water levels include central Columbia County, southern Jefferson County, and most of Union County. In the area around west-central Union County, water levels rose as much as 60.2 feet with water levels in 18 wells rising 20 feet or more, which is an average annual rise of 5 feet or more. Water levels generally declined throughout most of the Sparta-Memphis aquifer.

Hydrographs from 206 wells were constructed with a minimum of 25 years of water-level measurements. During the period 1985-2009, the county mean annual water level rose in Calhoun, Columbia, Lafayette, and Union Counties, about 1.3 feet per year ( $(\mathrm{ft} / \mathrm{yr}), 0.2 \mathrm{ft} / \mathrm{yr}, 0.1 \mathrm{ft} / \mathrm{yr}$, and $0.6 \mathrm{ft} / \mathrm{yr}$, respectively. In Union County, 2009 is the first year that the county mean has shown a rise since the county hydrograph analysis of water-level rise or decline was first used in 1996-97. Mean annual declines were between $0.5 \mathrm{ft} / \mathrm{yr}$ and Monroe, Nevada, Ouachita, Phillips, St. Francis, and Woodruff Counties. Mean annual declines were between $1.0 \mathrm{ft} / \mathrm{yr}$ and $0.5 \mathrm{ft} / \mathrm{yr}$ in Craighead, Desha, Drew, Lonoke, Mississippi, and Pulaski Counties. Mean annual declines were between $1.5 \mathrm{ft} / \mathrm{yr}$ and $1.0 \mathrm{ft} / \mathrm{yr}$ in Arkansas, Bradley, Cross, Jefferson, Lee, Poinsett, and Prairie Counties. The mean annual decline for Lincoln County was $2.3 \mathrm{ft} / \mathrm{yr}$. In western Arkansas County, water-level altitudes in a continuously monitored well changed 60 feet during the irrigation season (April to September).

Specific conductance ranged from 43 microsiemens per centimeter at 25 degrees Celsius $(\mu \mathrm{S} / \mathrm{cm})$ in Ouachita County to $1,230 \mu \mathrm{S} / \mathrm{cm}$ in Phillips County. The mean specific conductance was $392 \mu \mathrm{S} / \mathrm{cm}$. Although there is a regional increase in specific conductance to the east and south, anomalous increases occur in some parts of the study area. Large specific conductance values (greater than $700 \mu \mathrm{S} / \mathrm{cm}$ ) occur in samples from wells in Arkansas, Ashley, Monroe, Phillips, and Union Counties. The histograms of specific conductance data for 2009 and 2005 both have a right skew. The mean specific conductance was $362 \mu \mathrm{S} / \mathrm{cm}$ in 2005 and $392 \mu \mathrm{S} / \mathrm{cm}$ in 2009 . The $201-400 \mu \mathrm{S} / \mathrm{cm}$ range included 38 percent of the samples in 2005 and 53 percent of the samples in 2009. The lowest range, $1-200 \mu \mathrm{S} / \mathrm{cm}$, decreased from 33 percent of the samples in 2005 to 14 percent of the samples in 2009. The small change in the mean specific conductance and the distribution of data from 2005 to 2009 may indicate a change in water quality or may be the result of the distribution of sampling locations.

\section{Selected References}

Broom, M.E., Kraemer, T.F., and Bush, W.V., 1984, A reconnaissance study of saltwater contamination in the El Dorado aquifer, Union County, Arkansas: U.S. Geological Survey Water-Resources Investigations Report 84-4012, $47 \mathrm{p}$.
Edds, Joe, and Fitzpatrick, D.J., 1985, Maps showing altitude of the potentiometric surface and changes in water levels of the Sparta Sand and Memphis Sand aquifers in eastern Arkansas, spring 1984: U.S. Geological Survey WaterResources Investigations Report 85-4223, 1 sheet.

Edds, Joe, and Fitzpatrick, D.J., 1989, Altitude of the potentiometric surface and changes in water levels in the Sparta-Memphis aquifer in eastern and southern Arkansas, spring 1986: U.S. Geological Survey Water-Resources Investigations Report 88-4042, 1 sheet.

Fenneman, N.M., 1938, Physiography of eastern United States: New York, McGraw-Hill Book Co., Inc., 689 p.

Fenneman, N.M., and Johnson, D.W., 1946, Physical divisions of the United States (Map): Washington, D.C., U.S. Geological Survey, scale 1:7,000,000.

Fishman, M.J., and Friedman, L.C., 1989, Methods for determination of inorganic substances in water and fluvial sediments: U.S. Geological Survey Techniques of WaterResources Investigations, book 5, chap. A1, 545 p.

Freiwald, D.A., and Johnson, S.F., 2008, Monitoring of Sparta aquifer recovery in southern Arkansas and Northern Louisiana, 2003-07: U.S. Geological Survey Fact Sheet 2007-3102, 4 p.

Halberg, H.N., 1972, Use of water in Arkansas, 1970: Arkansas Geological Commission Water Resources Summary Number 7, 17 p.

Halberg, H.N., 1977, Use of water in Arkansas, 1975: Arkansas Geological Commission Water Resources Summary Number 9, 28 p.

Halberg, H.N., and Stephens, J.W., 1966, Use of water in Arkansas, 1965: Arkansas Geological Commission Water Resources Summary Number 5, 12 p.

Hart, R.M., Clark, B.R., and Bolyard, S.E., 2008, Digital surfaces and thicknesses of selected hydrogeologic units within the Mississippi Embayment regional aquifer study (MERAS): U.S. Geological Survey Scientific Investigations Report 2008-5098, accessed March 9, 2009, at http://pubs. usgs.gov/sir/2008/5098/.

Helsel, D.R., and Hirsch, R.M., 1992, Statistical methods in water resources: New York, N.Y., Elsevier Science Publishing Co., 522 p.

Holland, T.W., 1987, Use of water in Arkansas, 1985: Arkansas Geological Commission Water Resources Summary Number 14, $30 \mathrm{p}$.

Holland, T.W., 1993, Use of water in Arkansas, 1990: U.S. Geological Survey Open-File Report 93-48, pamphlet.

Holland, T.W., 1999, Water use in Arkansas, 1995: U.S. Geological Survey Open-File Report 99-188, 1 sheet. 
Holland, T.W., 2004, Estimated water use in Arkansas, 2000: U.S. Geological Survey Scientific Investigations Report 2004-5230, $31 \mathrm{p}$.

Holland, T.W., 2007, Water use in Arkansas, 2005: U.S. Geological Survey Scientific Investigations Report 2007$5241,31 \mathrm{p}$.

Holland, T.W., and Ludwig, A.H., 1981, Use of water in Arkansas: Arkansas Geological Commission Water Resources Summary Number 14, 30 p.

Hosman, R.L., 1982, Outcropping Tertiary units in southern Arkansas: U.S. Geological Survey Miscellaneous Investigations Series I-1405, 1 sheet.

Hosman, R.L., Long, A.T., Lambert, T.W., and others, 1968, Tertiary aquifers in the Mississippi Embayment: U.S. Geological Survey Professional Paper 448-D, 29 p.

Hosman, R.L., and Weiss, J.S., 1991, Geohydrologic units of the Mississippi Embayment and Texas Coastal Uplands aquifer systems, South-Central United States: U.S. Geological Survey Professional Paper 1416-B, 19 p.

Joseph, R.L., 1998, Potentiometric surface of the Sparta aquifer in eastern and south-central Arkansas and northcentral Louisiana, and the Memphis aquifer in east-central Arkansas, October 1996-July 1997: U.S. Geological Survey Water-Resources Investigations Report 97-4282, 19 p.

Joseph, R.L., 2000, Status of water levels and selected waterquality conditions in the Sparta and Memphis aquifers in eastern and south-central Arkansas, 1999: U.S. Geological Survey Water-Resources Investigations Report 00-4009, $34 \mathrm{p}$.

Morris, E.E., and Bush, W.V., 1986, Extent and source of saltwater intrusion into the alluvial aquifer near Brinkley, Arkansas, 1984: U.S. Geological Survey Water-Resources Investigations Report 85-4322, 123 p.

Payne, J.N., 1968, Hydrologic significance of the lithofacies of the Sparta Sand in Arkansas, Louisiana, Mississippi, and Texas: U.S. Geological Survey Professional Paper 569-A, $17 \mathrm{p}$.

Petersen, J.C., Broom, M.E., and Bush, W.V., 1985, Geohydrologic units of the Gulf Coastal Plain in Arkansas: U.S. Geological Survey Water-Resources Investigations Report 85-4116, 20 p.
Schrader, T.P., 2004, Status of water levels and selected water-quality conditions in the Sparta-Memphis aquifer in Arkansas and the Sparta aquifer in Louisiana, springsummer 2001: U.S. Geological Survey Scientific Investigations Report 2004-5055, 52 p.

Schrader, T.P., 2006, Status of water levels and selected water-quality conditions in the Sparta-Memphis aquifer in Arkansas, spring-summer, 2003: U.S. Geological Survey Scientific Investigations Report 2006-5021, 43 p.

Schrader, T.P., 2008, Potentiometric surface in the SpartaMemphis aquifer of the Mississippi Embayment, spring 2007: U.S. Geological Survey Scientific Investigations Map 3014, 1 plate.

Schrader, T.P., 2009, Water levels and selected water-quality conditions in the Sparta-Memphis aquifer (middle Claiborne aquifer) in Arkansas, spring-summer 2007: U.S Geological Survey Scientific Investigations Report 20095207, 50 p.

Schrader, T.P., and Jones, J.S., 2007, Status of water levels and selected water-quality conditions in the SpartaMemphis aquifer in Arkansas and the status of water levels in the Sparta aquifer in Louisiana, spring 2005: U.S. Geological Survey Scientific Investigations Report 20075029, $66 \mathrm{p}$.

Snider, J.L., Calandro, A.J., and Shampine, W.J., 1972, Water resources of Union Parish, Louisiana: Department of Conservation, Louisiana Geological Survey, and Louisiana Department of Public Works Water Resources Bulletin No. 17,68 p.

Stanton, G.P., 1997, Potentiometric surface and specific conductance of the Sparta and Memphis aquifers in eastern and south-central Arkansas, 1995: U.S. Geological Survey Water-Resources Investigations Report 97-4119, $16 \mathrm{p}$.

U.S. Geological Survey, variously dated, National field manual for the collection of water-quality data: U.S. Geological Survey Techniques of Water-Resources Investigations, book 9, chaps. A1-A9, accessed April 25, 2013, at http://pubs.water.usgs.gov/twri9A. 



\section{Appendix 1-Water-Level Data Collected during Spring 2009 from Wells Completed in the Sparta-Memphis Aquifer in Arkansas}



Appendix 1. Water level data collected during spring 2009 from wells completed in the Sparta-Memphis aquifer in Arkansas.

[USGS, U.S. Geological Survey; ANRC, Arkansas Natural Resources Commission; NGVD 29, National Geodetic Vertical Datum of 1929; Horizontal coordinate information is referenced to the North American Datum of 1983 (NAD 83)]

\begin{tabular}{|c|c|c|c|c|c|c|c|}
\hline Station name & $\begin{array}{c}\text { Latitude } \\
\text { (degrees, } \\
\text { minutes, } \\
\text { seconds) }\end{array}$ & $\begin{array}{c}\text { Longitude } \\
\text { (degrees, } \\
\text { minutes, } \\
\text { seconds) }\end{array}$ & $\begin{array}{c}\text { Water-level } \\
\text { altitude } \\
\text { (feet above } \\
\text { NGVD 29) }\end{array}$ & $\begin{array}{l}\text { Depth to water } \\
\text { (feet below } \\
\text { land surface) }\end{array}$ & $\begin{array}{c}\text { Land-surface } \\
\text { datum } \\
\text { (feet above } \\
\text { NGVD 29) }\end{array}$ & $\begin{array}{c}\text { Date of } \\
\text { measurement }\end{array}$ & $\begin{array}{l}\text { Source } \\
\text { of data }\end{array}$ \\
\hline \multicolumn{8}{|c|}{ Arkansas County } \\
\hline 02S04W06CDB1 & 343312 & 912849 & 51 & 160.98 & 212 & $4 / 1 / 2009$ & USGS \\
\hline 02S04W23DAA1 & 343044 & 912355 & 67 & 141.41 & 208 & $4 / 1 / 2009$ & USGS \\
\hline 02S04W33BBB1 & 342922 & 912703 & 38 & 166.79 & 205 & $4 / 1 / 2009$ & USGS \\
\hline 02S05W16CBB1 & 343144 & 913319 & 40 & 172.68 & 213 & $4 / 2 / 2009$ & USGS \\
\hline 02S05W27BBB1 & 343028 & 913230 & 35 & 180.87 & 216 & $4 / 1 / 2009$ & USGS \\
\hline 02S05W34BDA1 & 342925 & 913148 & 34 & 181.77 & 216 & $4 / 1 / 2009$ & USGS \\
\hline 02S05W35AAB1 & 342930 & 913035 & 39 & 176.73 & 216 & $4 / 1 / 2009$ & USGS \\
\hline 03S04W02CCB1 & 342748 & 912458 & 52 & 149.71 & 202 & $4 / 1 / 2009$ & USGS \\
\hline 03S04W26CDA1 & 342421 & 912438 & 59 & 144.10 & 203 & $4 / 1 / 2009$ & USGS \\
\hline 03S05W02AAB1 & 342842 & 913034 & 35 & 174.79 & 210 & $4 / 1 / 2009$ & USGS \\
\hline 03S05W13BDC1 & 342631 & 913005 & 35 & 174.57 & 210 & $4 / 1 / 2009$ & USGS \\
\hline 03S05W15CBB1 & 342633 & 913229 & 29 & 176.86 & 206 & $4 / 1 / 2009$ & USGS \\
\hline 03S05W18CAB1 & 342629 & 913525 & 34 & 161.94 & 196 & $4 / 1 / 2009$ & USGS \\
\hline 03S05W28DAB1 & 342447 & 913240 & 30 & 173.68 & 204 & $4 / 1 / 2009$ & USGS \\
\hline 03S06W30BBD1 & 342516 & 914216 & 30 & 160.82 & 191 & $4 / 1 / 2009$ & USGS \\
\hline 04S01W04CBD1 & 342225 & 910808 & 86 & 110.47 & 196 & $3 / 31 / 2009$ & USGS \\
\hline 04S01W28BAA1 & 341927 & 910748 & 86 & 104.43 & 190 & $3 / 31 / 2009$ & USGS \\
\hline 04S04W11BCC1 & 342157 & 912502 & 42 & 155.82 & 198 & $4 / 2 / 2009$ & USGS \\
\hline 04S04W19CBB1 & 342004 & 912929 & 37 & 157.76 & 195 & $4 / 1 / 2009$ & USGS \\
\hline 04S04W22DAA1 & 342007 & 912515 & 36 & 158.64 & 195 & $4 / 2 / 2009$ & USGS \\
\hline 04S05W01BAA1 & 342322 & 912956 & 28 & 168.16 & 196 & $4 / 1 / 2009$ & USGS \\
\hline 04S05W05ACC1 & 342303 & 913413 & 34 & 152.33 & 186 & $4 / 23 / 2009$ & USGS \\
\hline 04S05W15AAA1 & 342132 & 913133 & 31 & 169.79 & 201 & $4 / 1 / 2009$ & USGS \\
\hline 04S05W36DCC1 & 341752 & 913004 & 38 & 158.02 & 196 & $4 / 1 / 2009$ & USGS \\
\hline 05S01W17BAA1 & 341551 & 910745 & 83 & 92.51 & 176 & $3 / 31 / 2009$ & USGS \\
\hline 05S03W04ADB1 & 341734 & 912007 & 46 & 142.39 & 188 & $3 / 31 / 2009$ & USGS \\
\hline 05S04W26ACA1 & 341358 & 912434 & 55 & 133.14 & 188 & $3 / 31 / 2009$ & USGS \\
\hline 05S05W36DAA1 & 341245 & 912947 & 33 & 146.88 & 180 & $3 / 31 / 2009$ & USGS \\
\hline 06S02W06ABB1 & 341228 & 911620 & 68 & 113.25 & 181 & $3 / 31 / 2009$ & USGS \\
\hline 06S02W17ADA1 & 341023 & 911453 & 75 & 112.68 & 188 & $3 / 31 / 2009$ & USGS \\
\hline 06S02W22CDB1 & 340904 & 911331 & 75 & 110.83 & 186 & $3 / 31 / 2009$ & USGS \\
\hline 06S03W27BAA 1 & 340859 & 912009 & 63 & 117.84 & 181 & $3 / 31 / 2009$ & USGS \\
\hline 07S02W28ABA1 & 340340 & 911411 & 77 & 103.53 & 181 & $3 / 31 / 2009$ & USGS \\
\hline 07S03W06ABC1 & 340702 & 912248 & 59 & 125.52 & 185 & $3 / 31 / 2009$ & USGS \\
\hline 08S02W09BCC1 & 340031 & 911448 & 75 & 99.32 & 174 & $3 / 31 / 2009$ & USGS \\
\hline
\end{tabular}




\section{Water Levels and Water Quality in the Sparta-Memphis Aquifer (Middle Claiborne Aquifer) in Arkansas}

Appendix 1. Water level data collected during spring 2009 from wells completed in the Sparta-Memphis aquifer in Arkansas.Continued

[USGS, U.S. Geological Survey; ANRC, Arkansas Natural Resources Commission; NGVD 29, National Geodetic Vertical Datum of 1929; Horizontal coordinate information is referenced to the North American Datum of 1983 (NAD 83)]

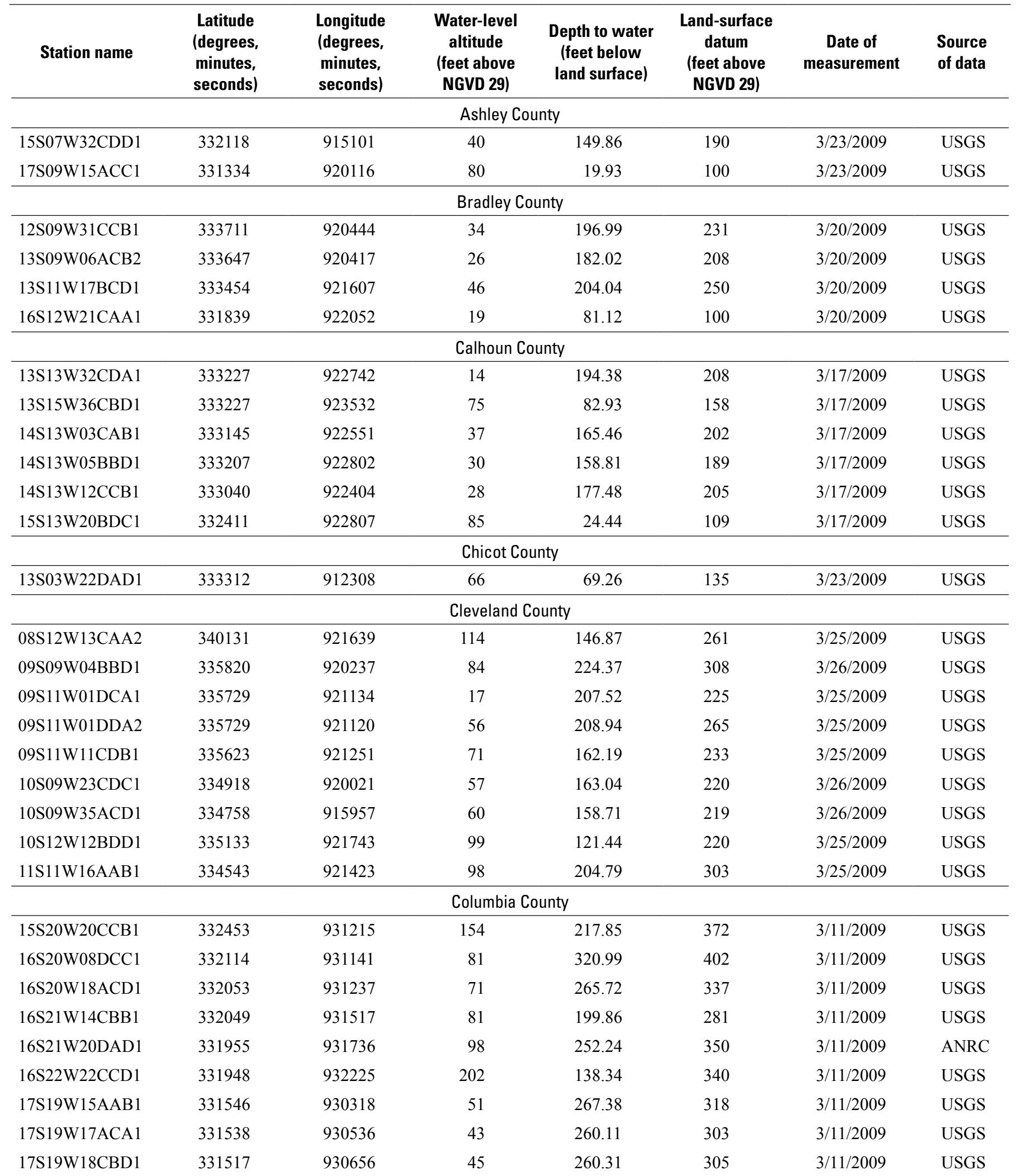


Appendix 1. Water level data collected during spring 2009 from wells completed in the Sparta-Memphis aquifer in Arkansas.Continued

[USGS, U.S. Geological Survey; ANRC, Arkansas Natural Resources Commission; NGVD 29, National Geodetic Vertical Datum of 1929; Horizontal coordinate information is referenced to the North American Datum of 1983 (NAD 83)]

\begin{tabular}{|c|c|c|c|c|c|c|c|}
\hline Station name & $\begin{array}{l}\text { Latitude } \\
\text { (degrees, } \\
\text { minutes, } \\
\text { seconds) }\end{array}$ & $\begin{array}{l}\text { Longitude } \\
\text { (degrees, } \\
\text { minutes, } \\
\text { seconds) } \\
\end{array}$ & $\begin{array}{l}\text { Water-level } \\
\text { altitude } \\
\text { (feet above } \\
\text { NGVD 29) }\end{array}$ & $\begin{array}{l}\text { Depth to water } \\
\text { (feet below } \\
\text { land surface) }\end{array}$ & $\begin{array}{l}\text { Land-surface } \\
\text { datum } \\
\text { (feet above } \\
\text { NGVD 29) }\end{array}$ & $\begin{array}{c}\text { Date of } \\
\text { measurement }\end{array}$ & $\begin{array}{l}\text { Source } \\
\text { of data }\end{array}$ \\
\hline \multicolumn{8}{|c|}{ Columbia County-Continued } \\
\hline 17S19W19BCA1 & 331433 & 930705 & 34 & 267.17 & 301 & $3 / 11 / 2009$ & USGS \\
\hline 17S19W30ABB1 & 331406 & 930650 & 30 & 217.72 & 248 & $3 / 11 / 2009$ & USGS \\
\hline 17S20W17CDA1 & 331520 & 931201 & 27 & 298.40 & 325.1 & $3 / 11 / 2009$ & USGS \\
\hline 17S20W36ABC1 & 331307 & 930755 & 42 & 292.97 & 335 & $3 / 12 / 2009$ & USGS \\
\hline 17S21W01BBC1 & 331743 & 931424 & 50 & 255.40 & 305 & $3 / 11 / 2009$ & USGS \\
\hline 17S21W08DCA1 & 331613 & 931758 & 93 & 206.53 & 300 & $3 / 11 / 2009$ & USGS \\
\hline 17S22W21ABD1 & 331517 & 932304 & 213 & 82.23 & 295 & $3 / 12 / 2009$ & USGS \\
\hline 17S22W22ABB1 & 331522 & 932210 & 186 & 135.13 & 321 & $3 / 12 / 2009$ & USGS \\
\hline 17S22W23BBB1 & 331521 & 932137 & 210 & 129.61 & 340 & $3 / 12 / 2009$ & USGS \\
\hline 18S20W06DDC1 & 331143 & 931249 & 4 & 295.65 & 300 & $3 / 11 / 2009$ & USGS \\
\hline 18S20W08CBC1 & 331115 & 931227 & -7 & 270.36 & 263 & $3 / 11 / 2009$ & USGS \\
\hline 18S20W10CAA1 & 331054 & 931016 & 14 & 276.42 & 290 & $3 / 11 / 2009$ & USGS \\
\hline 18S21W01ACC1 & 331223 & 931339 & -1 & 295.84 & 295 & $3 / 11 / 2009$ & USGS \\
\hline 18S21W17ACD1 & 331034 & 931759 & 85 & 230.16 & 315 & $3 / 10 / 2009$ & USGS \\
\hline 19S23W11DDB1 & 330605 & 932722 & 192 & 53.76 & 246 & 3/10/2009 & USGS \\
\hline 19S23W14BAB2 & 330555 & 932752 & 192 & 52.11 & 244 & $3 / 10 / 2009$ & USGS \\
\hline 20S22W03DCC1 & 330138 & 932236 & 162 & 52.40 & 214 & $3 / 10 / 2009$ & USGS \\
\hline 20S22W11ACD1 & 330109 & 932133 & 164 & 107.49 & 271 & $3 / 10 / 2009$ & USGS \\
\hline \multicolumn{8}{|c|}{ Craighead County } \\
\hline 13N03E23CDD1 & 354404 & 904433 & 157 & 91.25 & 248 & $4 / 14 / 2009$ & USGS \\
\hline 14N04E22CBD1 & 354929 & 903921 & 196 & 59.67 & 256 & $4 / 14 / 2009$ & USGS \\
\hline 14N04E28DBD1 & 354837 & 903953 & 189 & 64.89 & 254 & $4 / 14 / 2009$ & USGS \\
\hline 14N05E36CBC1 & 354751 & 903100 & 207 & 13.16 & 220 & $4 / 14 / 2009$ & USGS \\
\hline 15N04E20ADB1 & 355506 & 904043 & 319 & 119.08 & 438 & $4 / 14 / 2009$ & USGS \\
\hline 15N05E29DBB1 & 355360 & 903433 & 233 & 25.24 & 258 & $4 / 14 / 2009$ & USGS \\
\hline 15N06E18ACA1 & 355544 & 902858 & 211 & 18.66 & 230 & $4 / 14 / 2009$ & ANRC \\
\hline
\end{tabular}


Appendix 1. Water level data collected during spring 2009 from wells completed in the Sparta-Memphis aquifer in Arkansas.Continued

[USGS, U.S. Geological Survey; ANRC, Arkansas Natural Resources Commission; NGVD 29, National Geodetic Vertical Datum of 1929; Horizontal coordinate information is referenced to the North American Datum of 1983 (NAD 83)]

\begin{tabular}{|c|c|c|c|c|c|c|c|}
\hline Station name & $\begin{array}{c}\text { Latitude } \\
\text { (degrees, } \\
\text { minutes, } \\
\text { seconds) }\end{array}$ & $\begin{array}{c}\text { Longitude } \\
\text { (degrees, } \\
\text { minutes, } \\
\text { seconds) }\end{array}$ & $\begin{array}{c}\text { Water-level } \\
\text { altitude } \\
\text { (feet above } \\
\text { NGVD 29) }\end{array}$ & $\begin{array}{l}\text { Depth to water } \\
\text { (feet below } \\
\text { land surface) }\end{array}$ & $\begin{array}{c}\text { Land-surface } \\
\text { datum } \\
\text { (feet above } \\
\text { NGVD 29) }\end{array}$ & $\begin{array}{c}\text { Date of } \\
\text { measurement }\end{array}$ & $\begin{array}{l}\text { Source } \\
\text { of data }\end{array}$ \\
\hline \multicolumn{8}{|c|}{ Crittenden County } \\
\hline 05N08E11CCA2 & 350345 & 901300 & 185 & 25.88 & 211 & $4 / 8 / 2009$ & USGS \\
\hline 06N07E01DAD2 & 350958 & 901738 & 183 & 26.22 & 209 & $4 / 8 / 2009$ & USGS \\
\hline 09N07E21BBB1 & 352341 & 902131 & 190 & 26.17 & 216 & $4 / 8 / 2009$ & USGS \\
\hline \multicolumn{8}{|c|}{ Cross County } \\
\hline 06N04E06ACA1 & 351004 & 904238 & 152 & 205.58 & 358 & 4/9/2009 & USGS \\
\hline 07N05E04ADD1 & 351538 & 903330 & 173 & 35.80 & 209 & 4/9/2009 & USGS \\
\hline 09N03E22AAB2 & 352404 & 904518 & 148 & 129.23 & 277 & 4/9/2009 & USGS \\
\hline 09N03E22AAD1 & 352403 & 904512 & 144 & 134.24 & 278 & 4/9/2009 & USGS \\
\hline 09N04E30DCA1 & 352232 & 904218 & 158 & 271.39 & 429.32 & $4 / 9 / 2009$ & USGS \\
\hline \multicolumn{8}{|c|}{ Dallas County } \\
\hline 07S14W30DCC1 & 340431 & 923360 & 215 & 120.40 & 335 & $3 / 9 / 2009$ & USGS \\
\hline 07S14W31AAA1 & 340425 & 923334 & 218 & 112.36 & 330 & $3 / 9 / 2009$ & USGS \\
\hline 07S16W20CAB1 & 340555 & 924545 & 295 & 26.95 & 322 & $3 / 9 / 2009$ & USGS \\
\hline 08S15W34BDC1 & 335859 & 923730 & 214 & 26.32 & 240 & $3 / 9 / 2009$ & USGS \\
\hline 10S14W27CDB1 & 334908 & 923138 & 238 & 32.36 & 270 & $3 / 9 / 2009$ & USGS \\
\hline 10S15W18BCC1 & 335120 & 924120 & 252 & 76.44 & 328 & $3 / 9 / 2009$ & USGS \\
\hline \multicolumn{8}{|c|}{ Desha County } \\
\hline 09S02W26AAC1 & 335346 & 911521 & 79 & 73.83 & 153 & $3 / 24 / 2009$ & USGS \\
\hline 09S04W28DDD1 & 335310 & 913007 & 51 & 113.98 & 165 & $3 / 24 / 2009$ & USGS \\
\hline 10S02W26CCC2 & 334750 & 911624 & 71 & 77.24 & 148 & $3 / 24 / 2009$ & USGS \\
\hline 10S04W11CBC1 & 335034 & 912905 & 54 & 107.07 & 161 & $3 / 24 / 2009$ & USGS \\
\hline 11S02W03CCA1 & 334616 & 911711 & 67 & 71.64 & 139 & $3 / 24 / 2009$ & USGS \\
\hline 12S03W26CBB1 & 333749 & 912259 & 41 & 102.01 & 143 & $3 / 24 / 2009$ & USGS \\
\hline 12S03W34DAD1 & 333643 & 912305 & 62 & 84.63 & 147 & $3 / 24 / 2009$ & USGS \\
\hline
\end{tabular}


Appendix 1. Water level data collected during spring 2009 from wells completed in the Sparta-Memphis aquifer in Arkansas.Continued

[USGS, U.S. Geological Survey; ANRC, Arkansas Natural Resources Commission; NGVD 29, National Geodetic Vertical Datum of 1929; Horizontal coordinate information is referenced to the North American Datum of 1983 (NAD 83)]

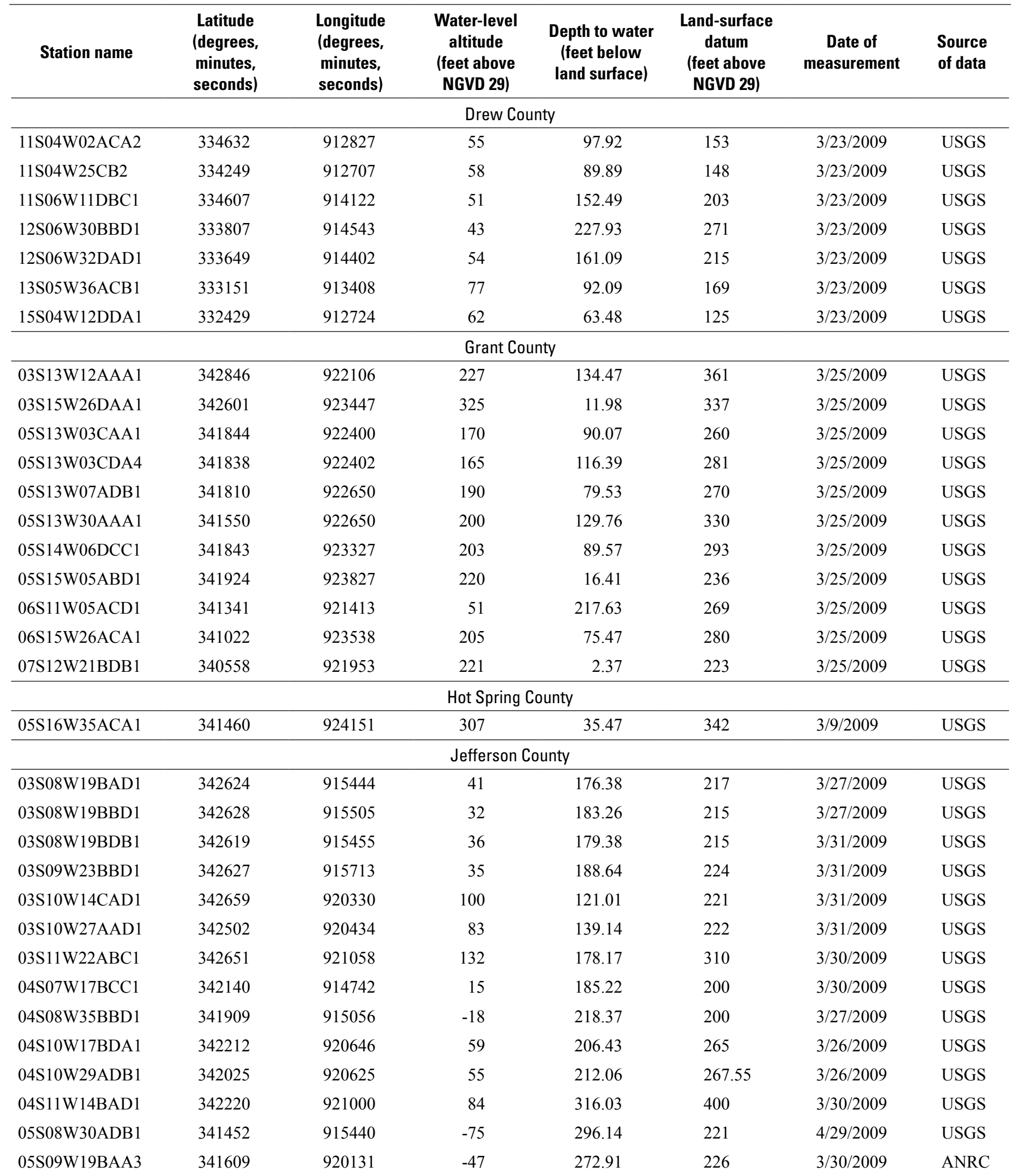


Appendix 1. Water level data collected during spring 2009 from wells completed in the Sparta-Memphis aquifer in Arkansas.Continued

[USGS, U.S. Geological Survey; ANRC, Arkansas Natural Resources Commission; NGVD 29, National Geodetic Vertical Datum of 1929; Horizontal coordinate information is referenced to the North American Datum of 1983 (NAD 83)]

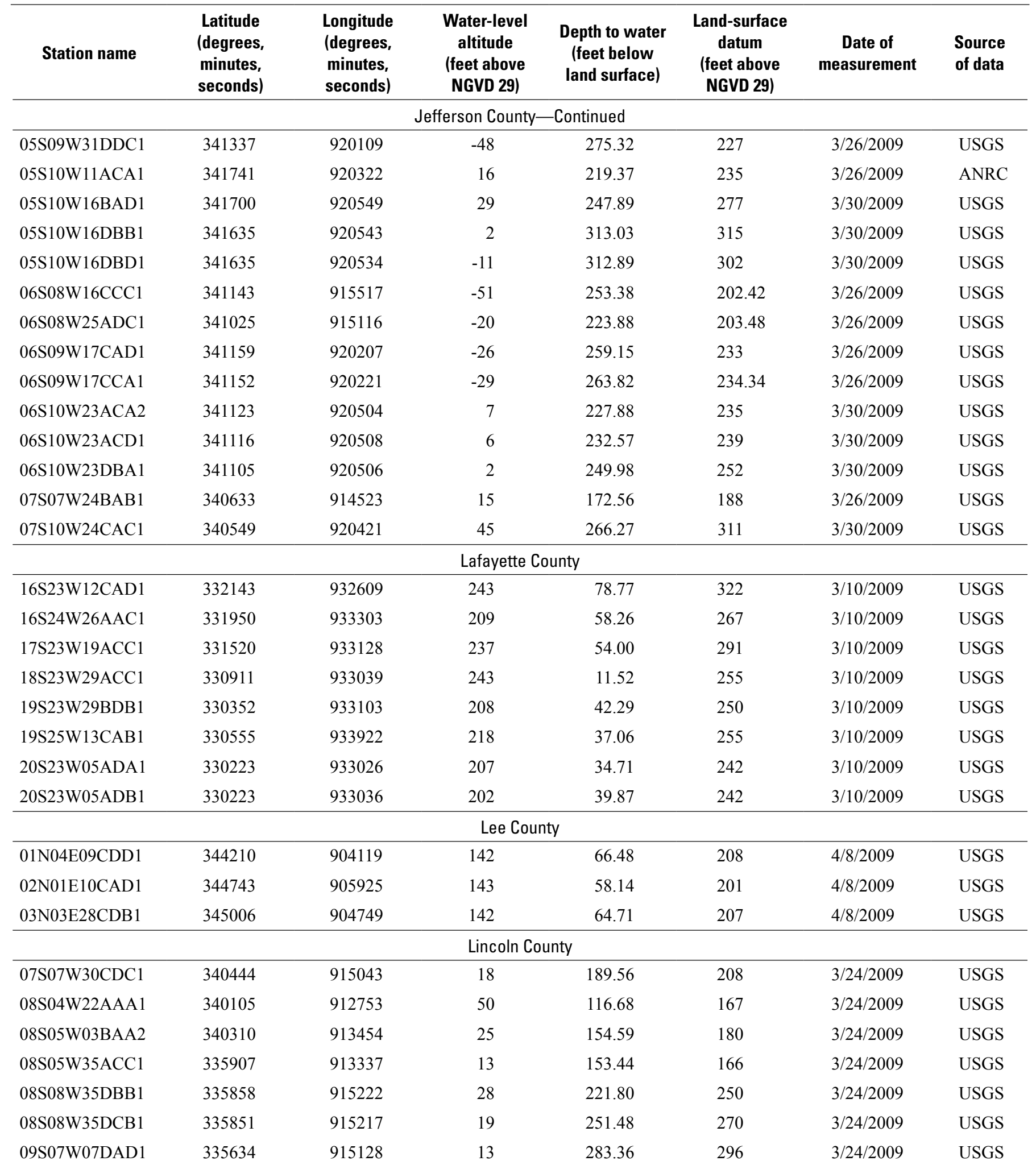


Appendix 1. Water level data collected during spring 2009 from wells completed in the Sparta-Memphis aquifer in Arkansas.Continued

[USGS, U.S. Geological Survey; ANRC, Arkansas Natural Resources Commission; NGVD 29, National Geodetic Vertical Datum of 1929; Horizontal coordinate information is referenced to the North American Datum of 1983 (NAD 83)]

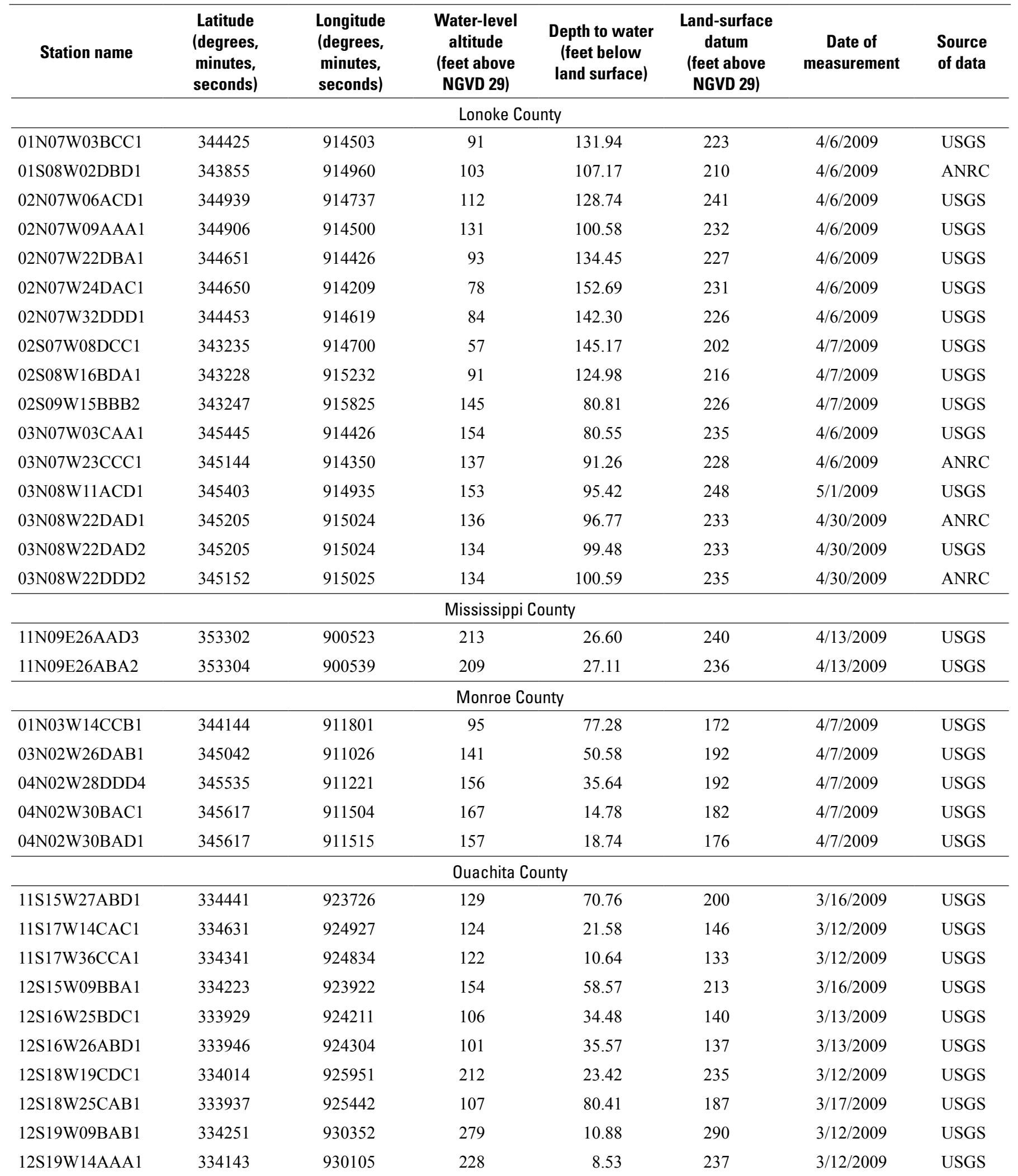




\section{Water Levels and Water Quality in the Sparta-Memphis Aquifer (Middle Claiborne Aquifer) in Arkansas}

Appendix 1. Water level data collected during spring 2009 from wells completed in the Sparta-Memphis aquifer in Arkansas.Continued

[USGS, U.S. Geological Survey; ANRC, Arkansas Natural Resources Commission; NGVD 29, National Geodetic Vertical Datum of 1929; Horizontal coordinate information is referenced to the North American Datum of 1983 (NAD 83)]

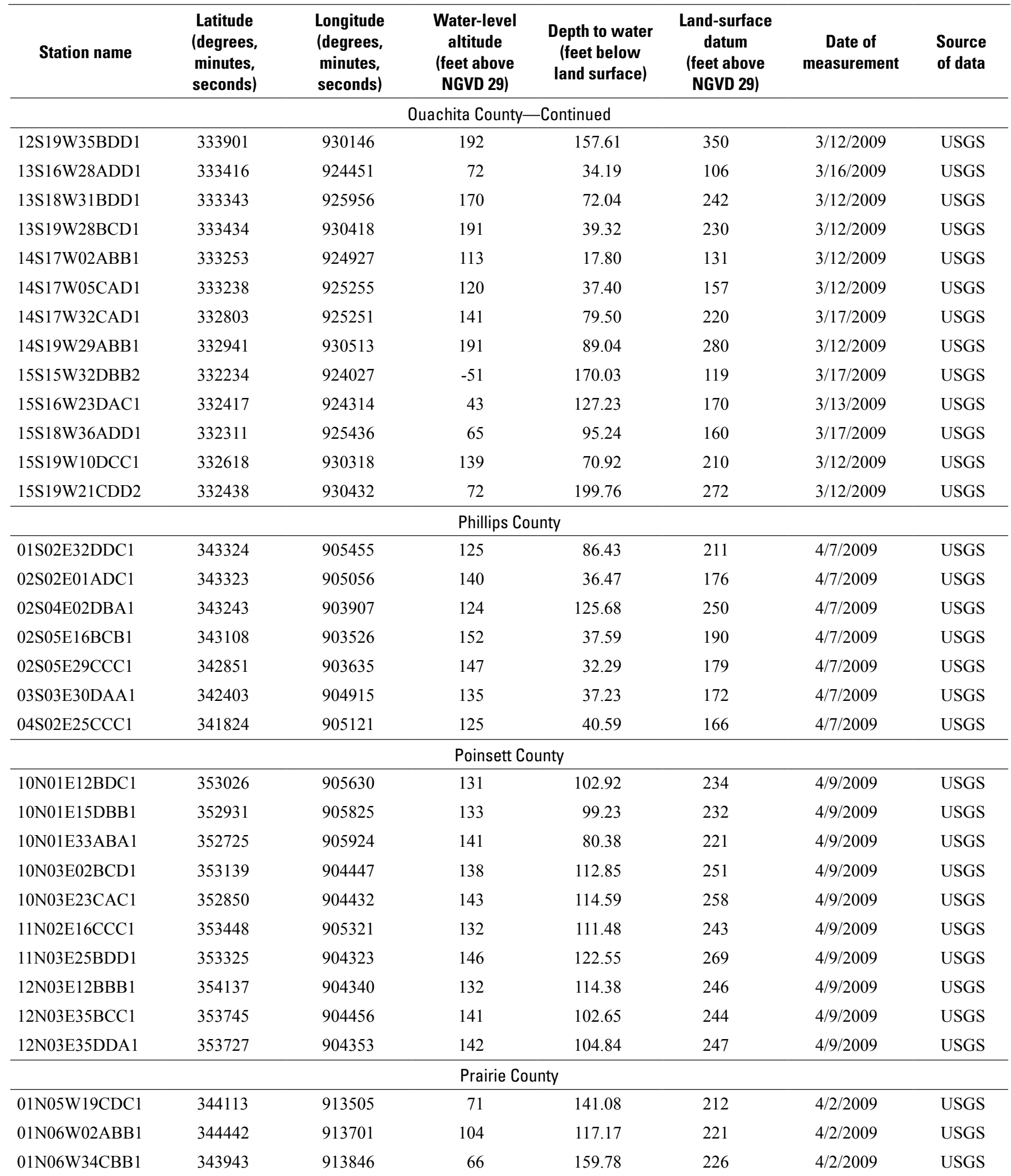


Appendix 1. Water level data collected during spring 2009 from wells completed in the Sparta-Memphis aquifer in Arkansas.Continued

[USGS, U.S. Geological Survey; ANRC, Arkansas Natural Resources Commission; NGVD 29, National Geodetic Vertical Datum of 1929; Horizontal coordinate information is referenced to the North American Datum of 1983 (NAD 83)]

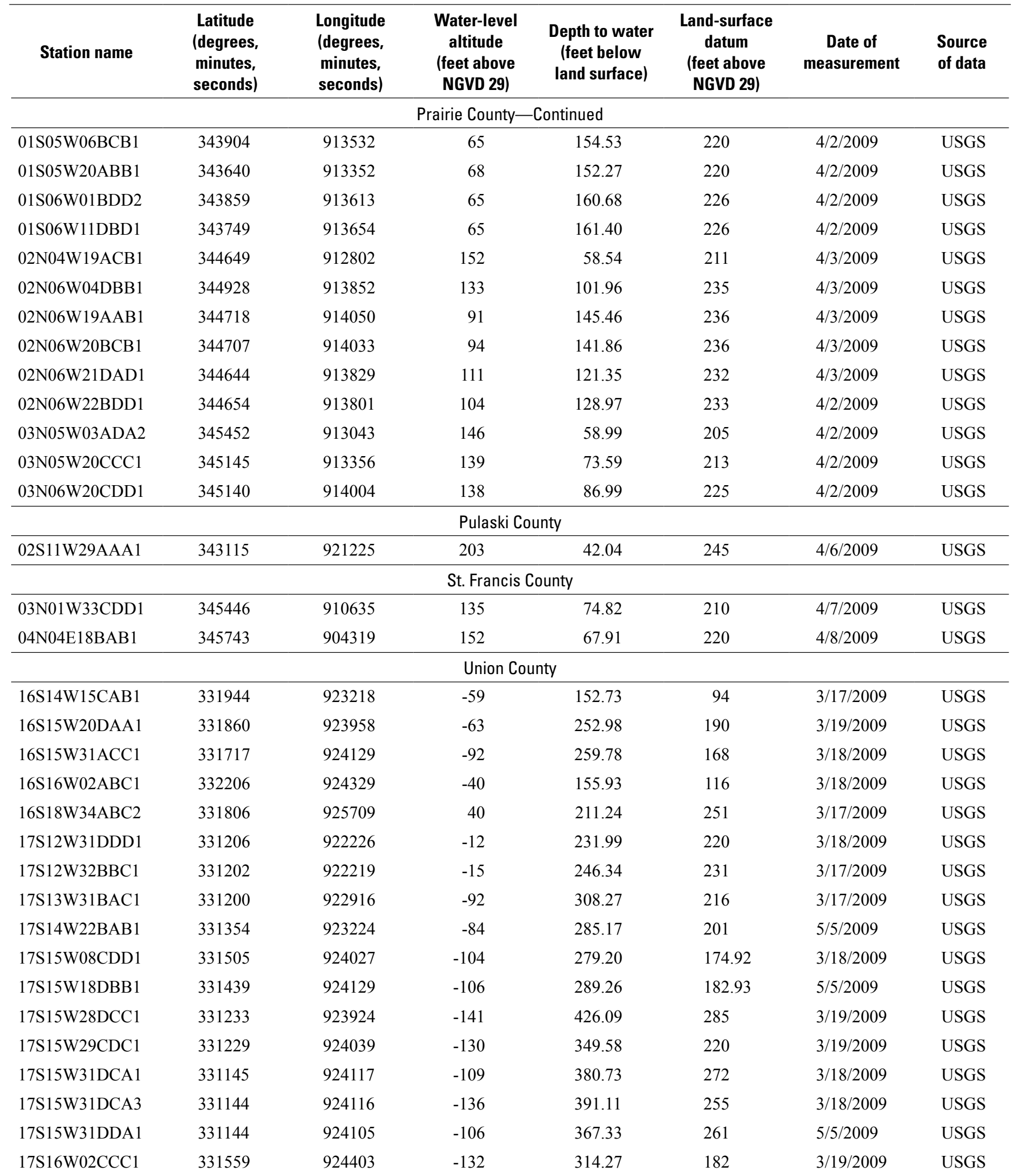




\section{Water Levels and Water Quality in the Sparta-Memphis Aquifer (Middle Claiborne Aquifer) in Arkansas}

Appendix 1. Water level data collected during spring 2009 from wells completed in the Sparta-Memphis aquifer in Arkansas.Continued

[USGS, U.S. Geological Survey; ANRC, Arkansas Natural Resources Commission; NGVD 29, National Geodetic Vertical Datum of 1929; Horizontal coordinate information is referenced to the North American Datum of 1983 (NAD 83)]

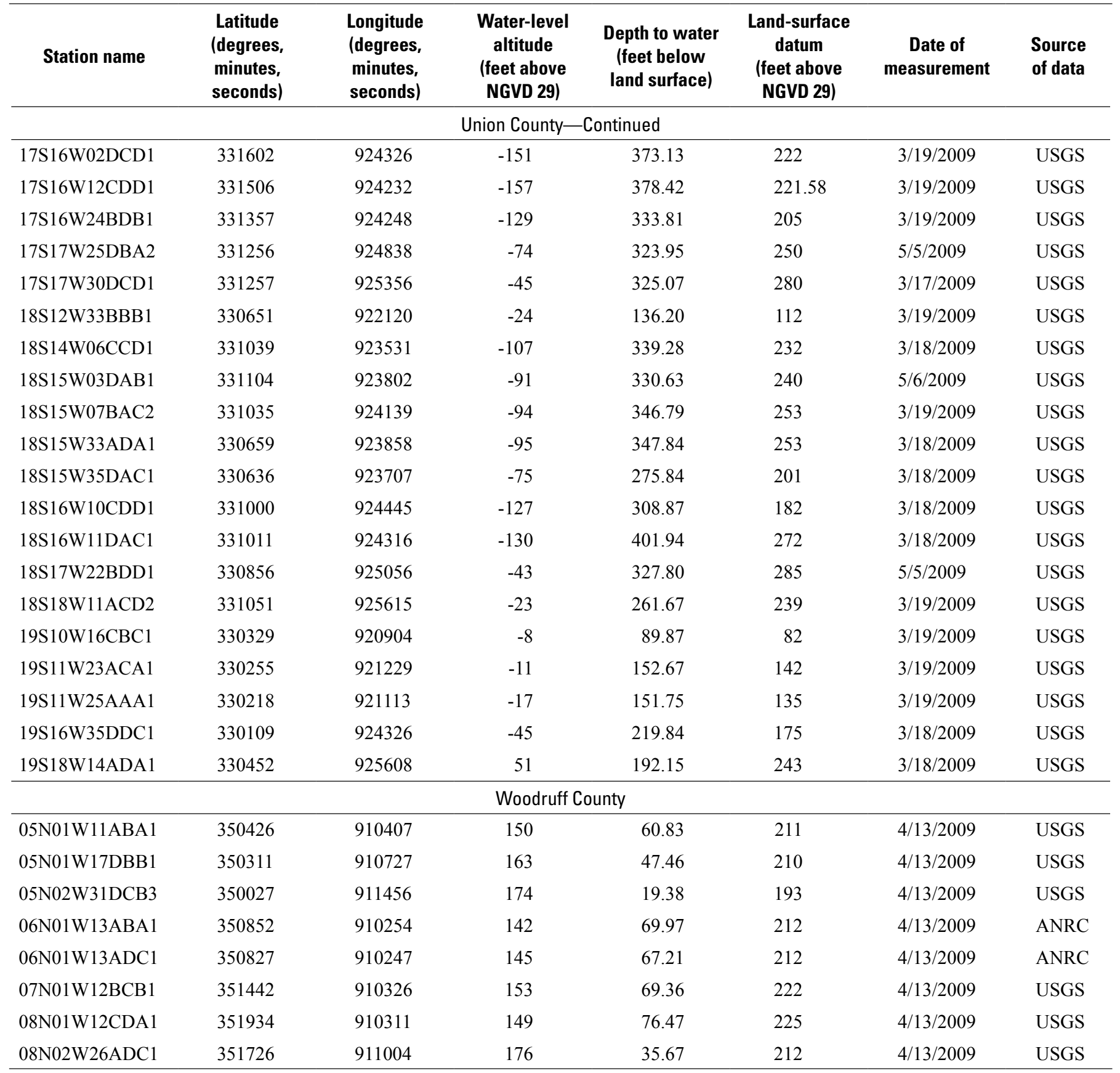




\section{Appendix 2-Difference in Water Level from 2005 to 2009 in the Sparta-Memphis Aquifer in Arkansas}



Appendix 2. Difference in water level from 2005 to 2009 in the Sparta-Memphis aquifer in Arkansas.

[Horizontal coordinate information is referenced to the North American Datum of 1983 (NAD 83); Negative values denote a decline; 2005 depth to water level from Schrader, 2007]

\begin{tabular}{|c|c|c|c|c|c|}
\hline Station name & $\begin{array}{c}\text { Latitude } \\
\text { (degrees, } \\
\text { minutes, seconds) }\end{array}$ & $\begin{array}{c}\text { Longitude } \\
\text { (degrees, } \\
\text { minutes, seconds) }\end{array}$ & $\begin{array}{l}2005 \text { depth to water } \\
\text { (feet below land- } \\
\text { surface datum }\end{array}$ & $\begin{array}{l}2009 \text { depth to water } \\
\text { (feet below land- } \\
\text { surface datum }\end{array}$ & $\begin{array}{c}\text { Difference in water } \\
\text { level from } 2005 \text { to } 2009 \\
\text { (feet) }\end{array}$ \\
\hline \multicolumn{6}{|c|}{ Arkansas County } \\
\hline 02S04W06CDB1 & 343312 & 912849 & 154.52 & 160.98 & -6.5 \\
\hline 02S04W23DAA1 & 343044 & 912355 & 143.61 & 141.41 & 2.2 \\
\hline 02S05W27BBB1 & 343028 & 913230 & 164.26 & 180.87 & -16.6 \\
\hline 02S05W34BDA1 & 342925 & 913148 & 174.64 & 181.77 & -7.1 \\
\hline 02S05W35AAB1 & 342930 & 913035 & 171.05 & 176.73 & -5.7 \\
\hline 03S04W02CCB1 & 342748 & 912458 & 144.05 & 149.71 & -5.7 \\
\hline 03S05W15CBB1 & 342633 & 913229 & 163.54 & 176.86 & -13.3 \\
\hline 03S05W18CAB1 & 342629 & 913525 & 156.28 & 161.94 & -5.7 \\
\hline 03S05W28DAB1 & 342447 & 913240 & 167.89 & 173.68 & -5.8 \\
\hline 03S06W30BBD1 & 342516 & 914216 & 161.27 & 160.82 & 0.5 \\
\hline 04S01W04CBD1 & 342225 & 910808 & 107.52 & 110.47 & -3.0 \\
\hline 04S04W11BCC1 & 342157 & 912502 & 151.06 & 155.82 & -4.8 \\
\hline 04S04W19CBB1 & 342004 & 912929 & 151.75 & 157.76 & -6.0 \\
\hline 04S04W22DAA1 & 342007 & 912515 & 155.51 & 158.64 & -3.1 \\
\hline 05S03W04ADB1 & 341734 & 912007 & 156.52 & 142.39 & 14.1 \\
\hline 05S04W26ACA1 & 341358 & 912434 & 119.78 & 133.14 & -13.4 \\
\hline 05S05W36DAA1 & 341245 & 912947 & 133.87 & 146.88 & -13.0 \\
\hline 06S02W06ABB1 & 341228 & 911620 & 102.32 & 113.25 & -10.9 \\
\hline 06S02W17ADA1 & 341023 & 911453 & 104.83 & 112.68 & -7.9 \\
\hline 06S02W22CDB1 & 340904 & 911331 & 98.12 & 110.83 & -12.7 \\
\hline 06S03W27BAA1 & 340859 & 912009 & 112.51 & 117.84 & -5.3 \\
\hline 07S02W28ABA1 & 340340 & 911411 & 98.23 & 103.53 & -5.3 \\
\hline 07S03W06ABC1 & 340702 & 912248 & 122.84 & 125.52 & -2.7 \\
\hline 08S02W09BCC1 & 340031 & 911448 & 95.88 & 99.32 & -3.4 \\
\hline \multicolumn{6}{|c|}{ Ashley County } \\
\hline 15S07W32CDD1 & 332118 & 915101 & 138.72 & 149.86 & -11.1 \\
\hline 17S09W15ACC1 & 331334 & 920116 & 17.97 & 19.93 & -2.0 \\
\hline
\end{tabular}


Appendix 2. Difference in water level from 2005 to 2009 in the Sparta-Memphis aquifer in Arkansas.-Continued

[Horizontal coordinate information is referenced to the North American Datum of 1983 (NAD 83); Negative values denote a decline; 2005 depth to water level from Schrader, 2007]

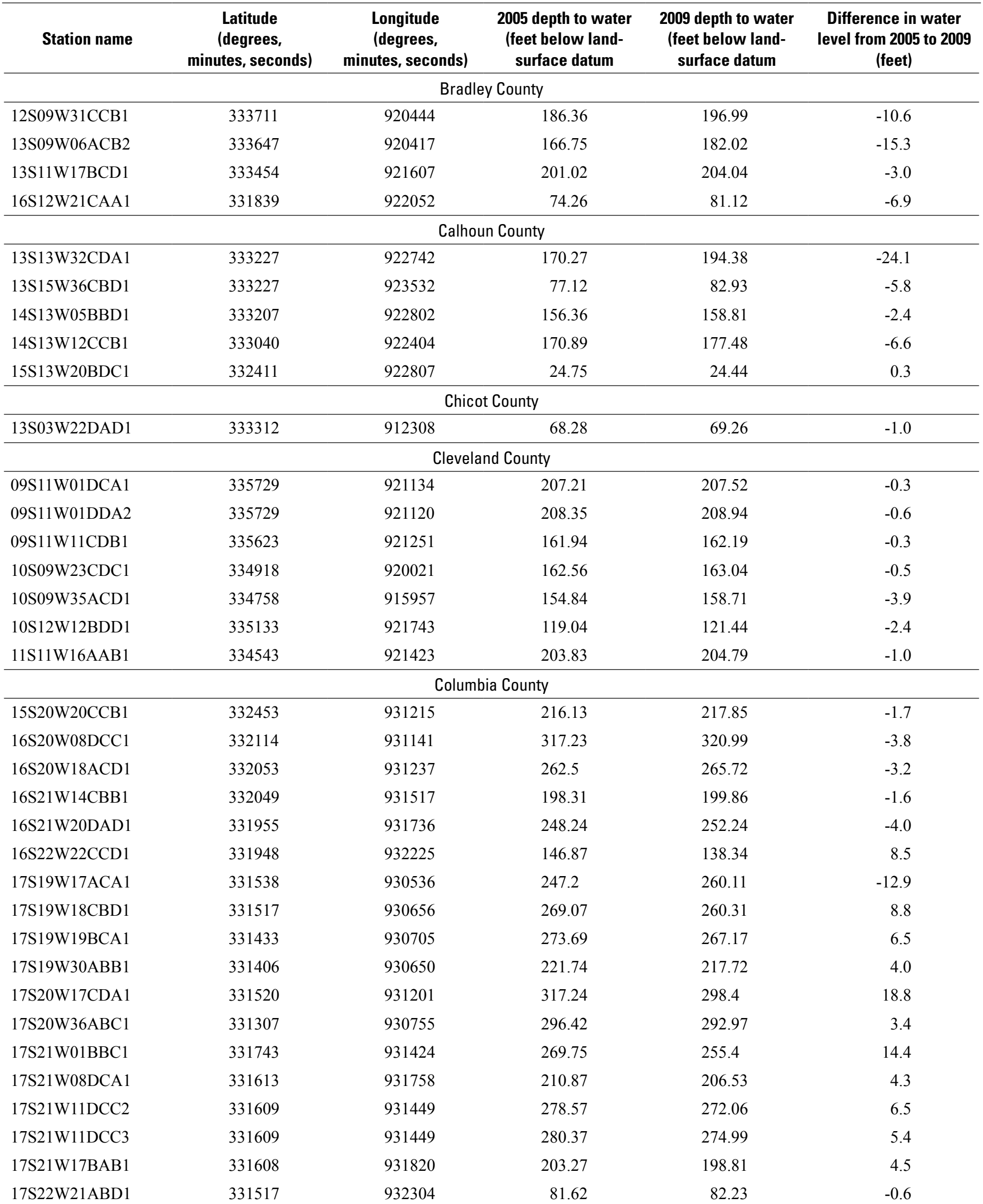


Appendix 2. Difference in water level from 2005 to 2009 in the Sparta-Memphis aquifer in Arkansas.-Continued

[Horizontal coordinate information is referenced to the North American Datum of 1983 (NAD 83); Negative values denote a decline; 2005 depth to water level from Schrader, 2007]

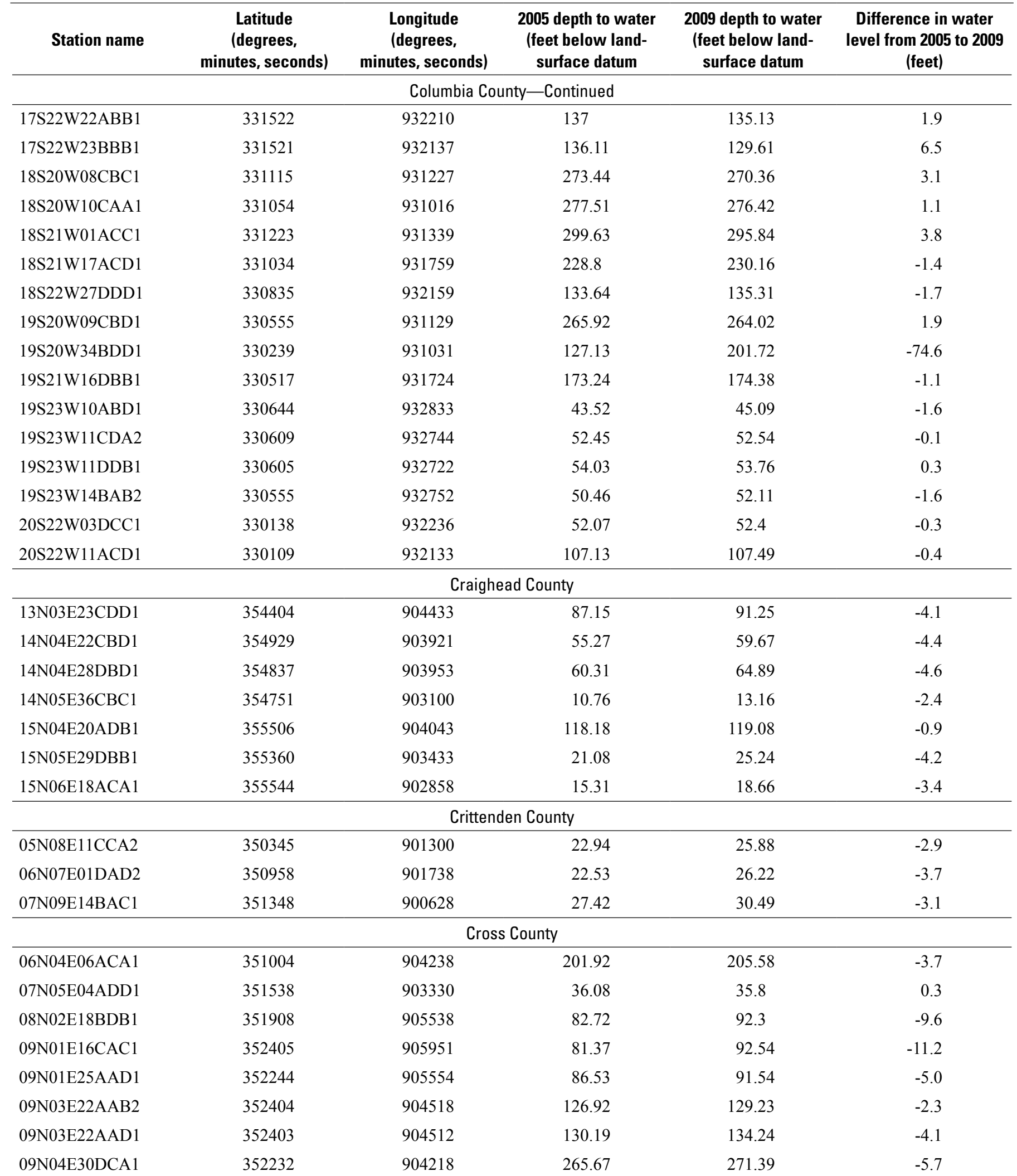




\section{Water Levels and Water Quality in the Sparta-Memphis Aquifer (Middle Claiborne Aquifer) in Arkansas}

Appendix 2. Difference in water level from 2005 to 2009 in the Sparta-Memphis aquifer in Arkansas.-Continued

[Horizontal coordinate information is referenced to the North American Datum of 1983 (NAD 83); Negative values denote a decline; 2005 depth to water level from Schrader, 2007]

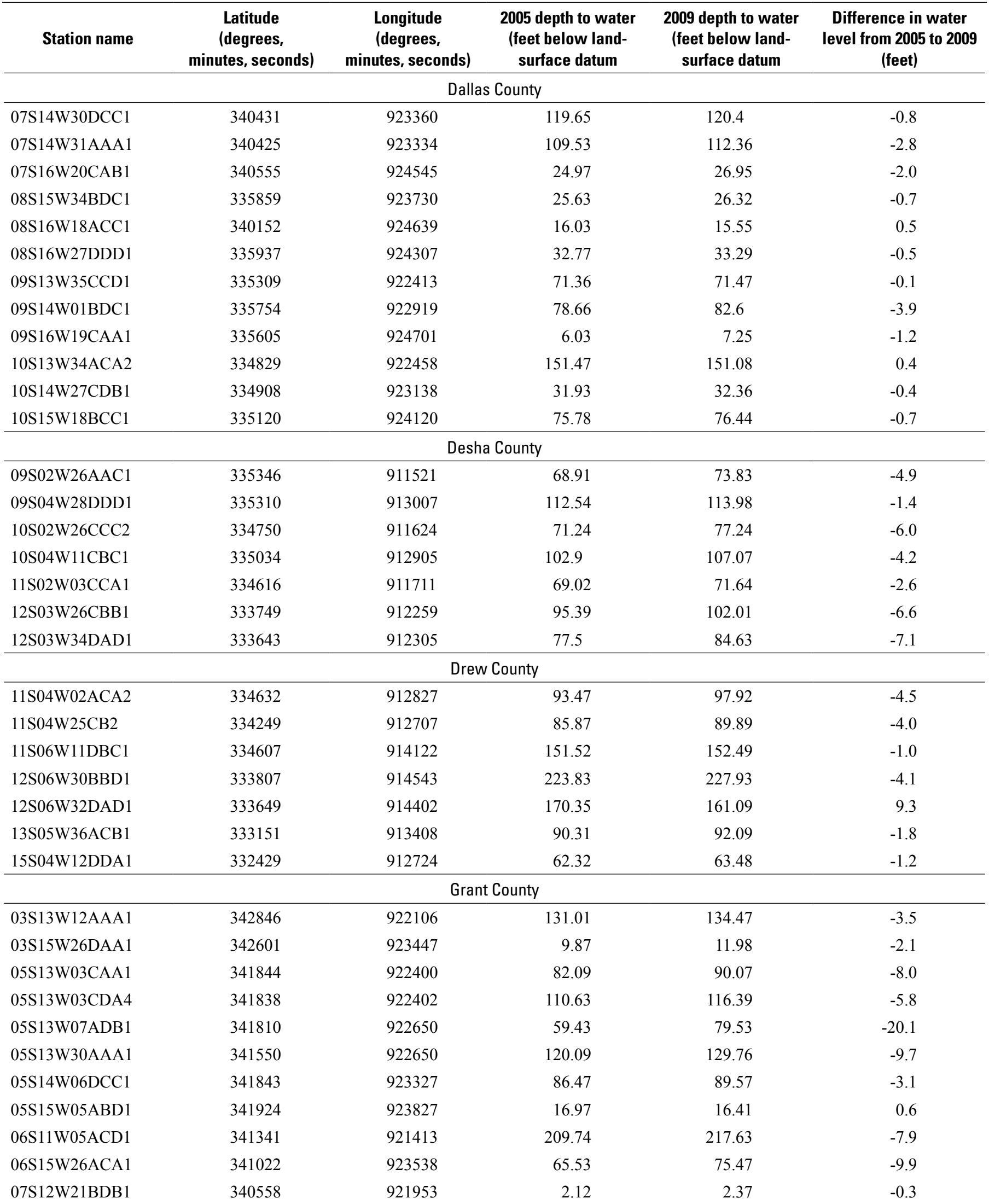


Appendix 2. Difference in water level from 2005 to 2009 in the Sparta-Memphis aquifer in Arkansas.-Continued

[Horizontal coordinate information is referenced to the North American Datum of 1983 (NAD 83); Negative values denote a decline; 2005 depth to water level from Schrader, 2007]

\begin{tabular}{|c|c|c|c|c|c|}
\hline Station name & $\begin{array}{c}\text { Latitude } \\
\text { (degrees, } \\
\text { minutes, seconds) }\end{array}$ & $\begin{array}{c}\text { Longitude } \\
\text { (degrees, } \\
\text { minutes, seconds) }\end{array}$ & $\begin{array}{l}2005 \text { depth to water } \\
\text { (feet below land- } \\
\text { surface datum }\end{array}$ & $\begin{array}{l}2009 \text { depth to water } \\
\text { (feet below land- } \\
\text { surface datum }\end{array}$ & $\begin{array}{c}\text { Difference in water } \\
\text { level from } 2005 \text { to } 2009 \\
\text { (feet) }\end{array}$ \\
\hline \multicolumn{6}{|c|}{ Jefferson County } \\
\hline 03S08W19BAD1 & 342624 & 915444 & 171.47 & 176.38 & -4.9 \\
\hline 03S08W19BBD1 & 342628 & 915505 & 166.74 & 183.26 & -16.5 \\
\hline 03S10W14CAD1 & 342659 & 920330 & 113.8 & 121.01 & -7.2 \\
\hline 03S10W27AAD1 & 342502 & 920434 & 126.25 & 139.14 & -12.9 \\
\hline 03S11W22ABC1 & 342651 & 921058 & 174.99 & 178.17 & -3.2 \\
\hline 04S07W17BCC1 & 342140 & 914742 & 168.4 & 185.22 & -16.8 \\
\hline 04S11W14BAD1 & 342220 & 921000 & 309.76 & 316.03 & -6.3 \\
\hline 05S08W30ADB1 & 341452 & 915440 & 297.47 & 296.14 & 1.3 \\
\hline 05S09W19BAA3 & 341609 & 920131 & 257.64 & 272.91 & -15.3 \\
\hline 05S09W31DDC1 & 341337 & 920109 & 276.94 & 275.32 & 1.6 \\
\hline 05S10W11ACA1 & 341741 & 920322 & 171.02 & 219.37 & -48.4 \\
\hline 05S10W16BAD1 & 341700 & 920549 & 241.67 & 247.89 & -6.2 \\
\hline 05S10W16DBB1 & 341635 & 920543 & 294.23 & 313.03 & -18.8 \\
\hline 05S10W16DBD1 & 341635 & 920534 & 283.89 & 312.89 & -29.0 \\
\hline 06S10W23ACD1 & 341116 & 920508 & 223.97 & 232.57 & -8.6 \\
\hline 06S10W23DBA1 & 341105 & 920506 & 237.29 & 249.98 & -12.7 \\
\hline 07S07W24BAB1 & 340633 & 914523 & 164.84 & 172.56 & -7.7 \\
\hline 07S10W24CAC1 & 340549 & 920421 & 305.17 & 266.27 & 38.9 \\
\hline \multicolumn{6}{|c|}{ Lafayette County } \\
\hline 16S23W12CAD1 & 332143 & 932609 & 74.85 & 78.77 & -3.9 \\
\hline 16S24W26AAC1 & 331950 & 933303 & 54.65 & 58.26 & -3.6 \\
\hline 17S23W19ACC1 & 331520 & 933128 & 51.57 & 54 & -2.4 \\
\hline 18S23W29ACC1 & 330911 & 933039 & 12.23 & 11.52 & 0.7 \\
\hline 19S23W29BDB1 & 330352 & 933103 & 41.56 & 42.29 & -0.7 \\
\hline 19S25W13CAB1 & 330555 & 933922 & 38.5 & 37.06 & 1.4 \\
\hline 20S23W05ADA1 & 330223 & 933026 & 34.86 & 34.71 & 0.1 \\
\hline 20S23W05ADB1 & 330223 & 933036 & 40.15 & 39.87 & 0.3 \\
\hline
\end{tabular}




\section{Water Levels and Water Quality in the Sparta-Memphis Aquifer (Middle Claiborne Aquifer) in Arkansas}

Appendix 2. Difference in water level from 2005 to 2009 in the Sparta-Memphis aquifer in Arkansas.-Continued

[Horizontal coordinate information is referenced to the North American Datum of 1983 (NAD 83); Negative values denote a decline; 2005 depth to water level from Schrader, 2007]

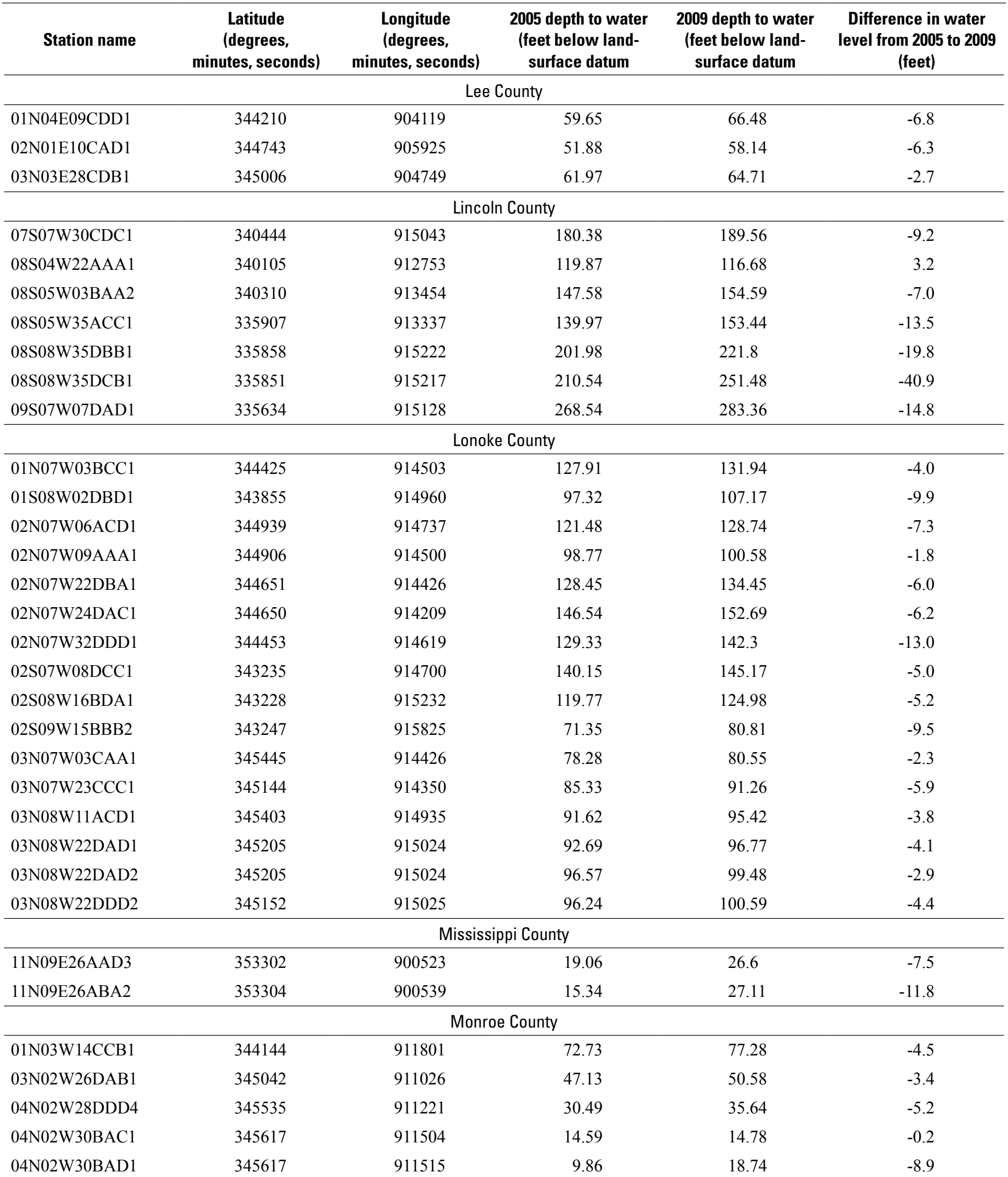


Appendix 2. Difference in water level from 2005 to 2009 in the Sparta-Memphis aquifer in Arkansas.-Continued

[Horizontal coordinate information is referenced to the North American Datum of 1983 (NAD 83); Negative values denote a decline; 2005 depth to water level from Schrader, 2007]

\begin{tabular}{|c|c|c|c|c|c|}
\hline Station name & $\begin{array}{c}\text { Latitude } \\
\text { (degrees, } \\
\text { minutes, seconds) }\end{array}$ & $\begin{array}{c}\text { Longitude } \\
\text { (degrees, } \\
\text { minutes, seconds) }\end{array}$ & $\begin{array}{l}2005 \text { depth to water } \\
\text { (feet below land- } \\
\text { surface datum }\end{array}$ & $\begin{array}{l}2009 \text { depth to water } \\
\text { (feet below land- } \\
\text { surface datum }\end{array}$ & $\begin{array}{l}\text { Difference in water } \\
\text { level from } 2005 \text { to } 2009 \\
\text { (feet) }\end{array}$ \\
\hline \multicolumn{6}{|c|}{ Ouachita County } \\
\hline 11S15W27ABD1 & 334441 & 923726 & 71.72 & 70.76 & 1.0 \\
\hline 11S17W14CAC1 & 334631 & 924927 & 18.7 & 21.58 & -2.9 \\
\hline 12S16W25BDC1 & 333929 & 924211 & 33.82 & 34.48 & -0.7 \\
\hline 12S16W26ABD1 & 333946 & 924304 & 34.69 & 35.57 & -0.9 \\
\hline 12S18W19CDC1 & 334014 & 925951 & 8 & 23.42 & -15.4 \\
\hline 12S18W25CAB1 & 333937 & 925442 & 77.43 & 80.41 & -3.0 \\
\hline 13S16W28ADD1 & 333416 & 924451 & 32.19 & 34.19 & -2.0 \\
\hline 13S18W31BDD1 & 333343 & 925956 & 70.02 & 72.04 & -2.0 \\
\hline 13S19W28BCD1 & 333434 & 930418 & 36.22 & 39.32 & -3.1 \\
\hline 14S17W05CAD1 & 333238 & 925255 & 36.93 & 37.4 & -0.5 \\
\hline 14S17W32CAD1 & 332803 & 925251 & 81.86 & 79.5 & 2.4 \\
\hline 14S19W29ABB1 & 332941 & 930513 & 87.52 & 89.04 & -1.5 \\
\hline 15S18W36ADD1 & 332311 & 925436 & 95.43 & 95.24 & 0.2 \\
\hline 15S19W10DCC1 & 332618 & 930318 & 73.25 & 70.92 & 2.3 \\
\hline 02S05E16BCB1 & 343108 & 903526 & 33.52 & 37.59 & -4.1 \\
\hline 02S05E29CCC1 & 342851 & 903635 & 34.96 & 32.29 & 2.7 \\
\hline 03S03E30DAA1 & 342403 & 904915 & 43.88 & 37.23 & 6.7 \\
\hline 04S02E25CCC1 & 341824 & 905121 & 35.99 & 40.59 & -4.6 \\
\hline \multicolumn{6}{|c|}{ Poinsett County } \\
\hline 10N01E12BDC1 & 353026 & 905630 & 95.1 & 102.92 & -7.8 \\
\hline 10N01E15DBB1 & 352931 & 905825 & 94.74 & 99.23 & -4.5 \\
\hline 10N01E33ABA1 & 352725 & 905924 & 75.44 & 80.38 & -4.9 \\
\hline 10N03E02BCD1 & 353139 & 904447 & 109.89 & 112.85 & -3.0 \\
\hline 10N03E23CAC1 & 352850 & 904432 & 111.69 & 114.59 & -2.9 \\
\hline $11 \mathrm{~N} 02 \mathrm{E} 16 \mathrm{CCC} 1$ & 353448 & 905321 & 105.49 & 111.48 & -6.0 \\
\hline 11N03E25BDD1 & 353325 & 904323 & 120.71 & 122.55 & -1.8 \\
\hline 12N03E12BBB1 & 354137 & 904340 & 96.67 & 114.38 & -17.7 \\
\hline 12N03E35BCC1 & 353745 & 904456 & 102.24 & 102.65 & -0.4 \\
\hline 12N03E35DDA1 & 353727 & 904353 & 101.36 & 104.84 & -3.5 \\
\hline
\end{tabular}


Appendix 2. Difference in water level from 2005 to 2009 in the Sparta-Memphis aquifer in Arkansas.-Continued

[Horizontal coordinate information is referenced to the North American Datum of 1983 (NAD 83); Negative values denote a decline; 2005 depth to water level from Schrader, 2007]

\begin{tabular}{|c|c|c|c|c|c|}
\hline Station name & $\begin{array}{c}\text { Latitude } \\
\text { (degrees, } \\
\text { minutes, seconds) }\end{array}$ & $\begin{array}{c}\text { Longitude } \\
\text { (degrees, } \\
\text { minutes, seconds) }\end{array}$ & $\begin{array}{l}2005 \text { depth to water } \\
\text { (feet below land- } \\
\text { surface datum }\end{array}$ & $\begin{array}{l}2009 \text { depth to water } \\
\text { (feet below land- } \\
\text { surface datum }\end{array}$ & $\begin{array}{c}\text { Difference in water } \\
\text { level from } 2005 \text { to } 2009 \\
\text { (feet) }\end{array}$ \\
\hline \multicolumn{6}{|c|}{ Prairie County } \\
\hline 01N05W19CDC1 & 344113 & 913505 & 139.47 & 141.08 & -1.6 \\
\hline 01N06W02ABB1 & 344442 & 913701 & 115.65 & 117.17 & -1.5 \\
\hline 01S05W20ABB1 & 343640 & 913352 & 158.85 & 152.27 & 6.6 \\
\hline 01S06W01BDD2 & 343859 & 913613 & 163.98 & 160.68 & 3.3 \\
\hline 01S06W11DBD1 & 343749 & 913654 & 164.72 & 161.4 & 3.3 \\
\hline 02N04W19ACB1 & 344649 & 912802 & 91.13 & 58.54 & 32.6 \\
\hline 02N06W22BDD1 & 344654 & 913801 & 118.96 & 128.97 & -10.0 \\
\hline 03N05W03ADA2 & 345452 & 913043 & 60.03 & 58.99 & 1.0 \\
\hline 03N05W20CCC1 & 345145 & 913356 & 70.41 & 73.59 & -3.2 \\
\hline 03N06W20CDD1 & 345140 & 914004 & 83.79 & 86.99 & -3.2 \\
\hline \multicolumn{6}{|c|}{ St. Francis County } \\
\hline 03N01W33CDD1 & 345446 & 910635 & 68.01 & 74.82 & -6.8 \\
\hline 04N04E18BAB1 & 345743 & 904319 & 63.28 & 67.91 & -4.6 \\
\hline \multicolumn{6}{|c|}{ Union County } \\
\hline 17S12W31DDD1 & 331206 & 922226 & 238.11 & 231.99 & 6.1 \\
\hline 17S12W32BBC1 & 331202 & 922219 & 250.58 & 246.34 & 4.2 \\
\hline 17S13W31BAC1 & 331200 & 922916 & 306.13 & 308.27 & -2.1 \\
\hline 17S14W22BAB1 & 331354 & 923224 & 317.24 & 285.17 & 32.1 \\
\hline 17S15W08CDD1 & 331505 & 924027 & 325.58 & 279.2 & 46.4 \\
\hline 17S15W18DBB1 & 331439 & 924129 & 331.1 & 289.26 & 41.8 \\
\hline 17S15W28DCC1 & 331233 & 923924 & 437.19 & 426.09 & 11.1 \\
\hline 17S15W29CDC1 & 331229 & 924039 & 373.46 & 349.58 & 23.9 \\
\hline 17S15W31DCA1 & 331145 & 924117 & 425.27 & 380.73 & 44.5 \\
\hline 17S15W31DDA1 & 331144 & 924105 & 414.99 & 367.33 & 47.7 \\
\hline 17S16W02CCC1 & 331559 & 924403 & 336.32 & 314.27 & 22.1 \\
\hline 17S16W02DCD1 & 331602 & 924326 & 387.68 & 373.13 & 14.6 \\
\hline 17S16W12CDD1 & 331506 & 924232 & 406.31 & 378.42 & 27.9 \\
\hline 17S16W24BDB1 & 331357 & 924248 & 394.04 & 333.81 & 60.2 \\
\hline 17S17W25DBA2 & 331256 & 924838 & 359 & 323.95 & 35.1 \\
\hline
\end{tabular}


Appendix 2. Difference in water level from 2005 to 2009 in the Sparta-Memphis aquifer in Arkansas.-Continued

[Horizontal coordinate information is referenced to the North American Datum of 1983 (NAD 83); Negative values denote a decline; 2005 depth to water level from Schrader, 2007]

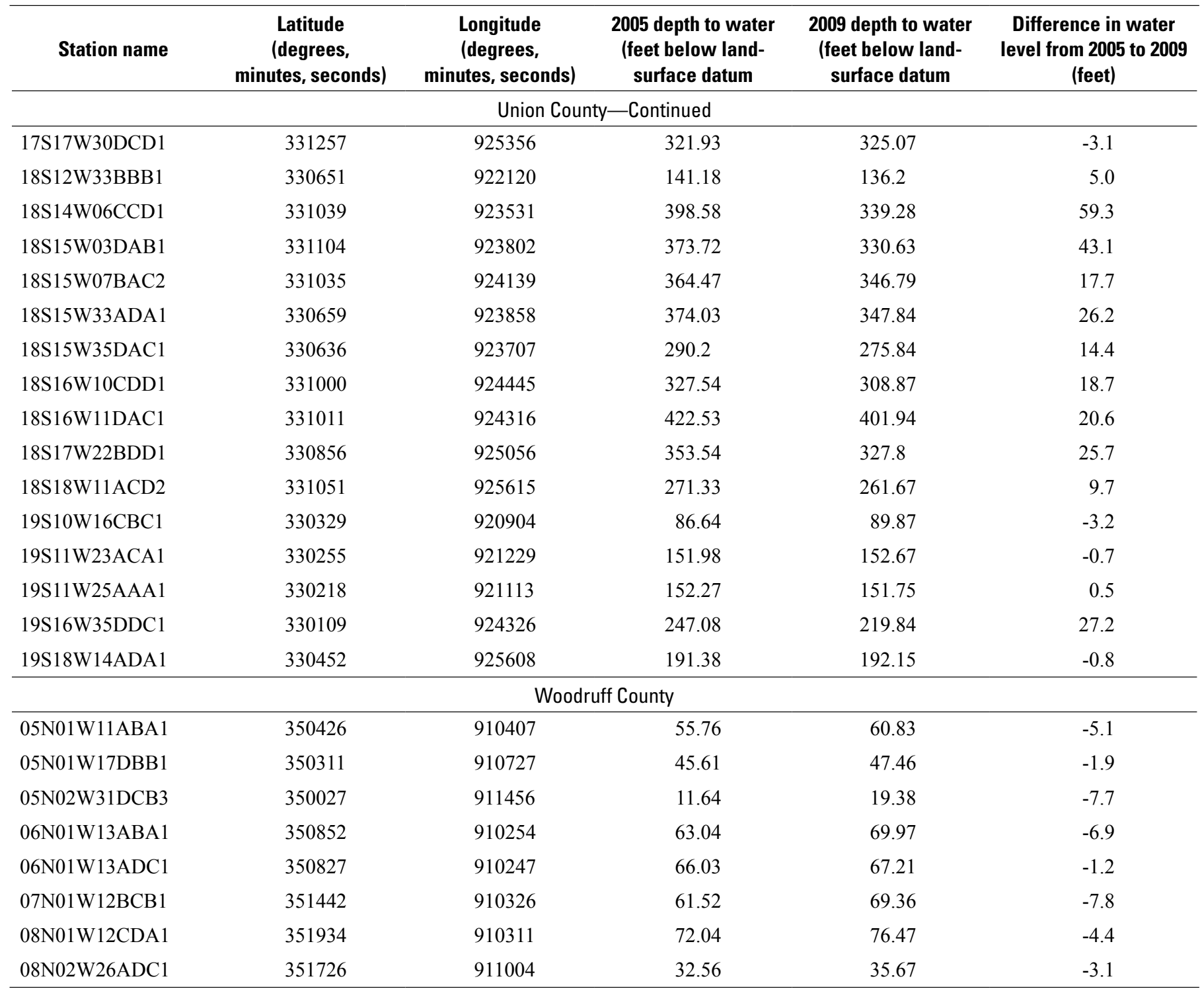





\section{Appendix 3-Specific Conductance, Temperature, and pH Data from Wells Completed in the Sparta-Memphis Aquifer in Arkansas, Summer 2009}



Appendix 3. Specific conductance, temperature and $\mathrm{pH}$ data from wells completed in the Sparta-Memphis aquifer in eastern Arkansas, summer 2009.

[Horizontal coordinate information is referenced to the North American Datum of 1983 (NAD 83); $\mu$ S/cm, microsiemens per centimeter at 25 degrees Celsius]

\begin{tabular}{|c|c|c|c|c|c|c|}
\hline Station name & $\begin{array}{l}\text { Latitude } \\
\text { (degrees, } \\
\text { minutes, } \\
\text { seconds) }\end{array}$ & $\begin{array}{l}\text { Longitude } \\
\text { (degrees, } \\
\text { minutes, } \\
\text { seconds) }\end{array}$ & Date & $\begin{array}{c}\text { Specific } \\
\text { conductance } \\
(\mu \mathrm{S} / \mathrm{cm})\end{array}$ & $\begin{array}{c}\text { Temperature } \\
\text { (degrees Celsius) }\end{array}$ & $\begin{array}{c}\mathrm{pH} \\
\text { (standard units) }\end{array}$ \\
\hline \multicolumn{7}{|c|}{ Arkansas County } \\
\hline 02S04W06CDB1 & 343312 & 912849 & $8 / 3 / 2009$ & 373 & 24.3 & 8.1 \\
\hline 04S01W04CBD1 & 342225 & 910808 & $8 / 3 / 2009$ & 794 & 26 & 7.7 \\
\hline \multicolumn{7}{|c|}{ Ashley County } \\
\hline 15S07W32CDD1 & 332118 & 915101 & $7 / 30 / 2009$ & 884 & 27.2 & 8.7 \\
\hline \multicolumn{7}{|c|}{ Bradley County } \\
\hline 13S09W06ACB2 & 333647 & 920417 & $7 / 30 / 2009$ & 372 & 27.9 & 8.4 \\
\hline 14S13W03CAB1 & 333145 & 922551 & $7 / 30 / 2009$ & 476 & 25.1 & 8.3 \\
\hline 14S13W12CCB1 & 333040 & 922404 & $7 / 21 / 2009$ & 455 & 23.2 & 8.7 \\
\hline 14S15W16BAA1 & 333055 & 923912 & $7 / 30 / 2009$ & 311 & 24.8 & 8.2 \\
\hline \multicolumn{7}{|c|}{ Cleveland County } \\
\hline 09S09W04BBD1 & 335820 & 920237 & $7 / 30 / 2009$ & 382 & 24.9 & 8.0 \\
\hline 11S11W16AAB1 & 334543 & 921423 & $7 / 30 / 2009$ & 300 & 26.3 & 8.0 \\
\hline \multicolumn{7}{|c|}{ Columbia County } \\
\hline 15S20W20CCB1 & 332453 & 931215 & $7 / 29 / 2009$ & 346 & 24.7 & 8.0 \\
\hline \multicolumn{7}{|c|}{ Craighead County } \\
\hline \multicolumn{7}{|c|}{ Crittenden County } \\
\hline 05N07E34CAA1 & 350017 & 901909 & $8 / 4 / 2009$ & 418 & 22.9 & 8.1 \\
\hline 06N09E23AAB1 & 350745 & 900553 & $8 / 4 / 2009$ & 247 & 23.8 & 7.9 \\
\hline \multicolumn{7}{|c|}{ Cross County } \\
\hline 07N05E04ADD1 & 351538 & 903330 & $8 / 12 / 2009$ & 227 & 21.3 & 7.4 \\
\hline 09N01E16CAC1 & 352405 & 905951 & $8 / 4 / 2009$ & 338 & 26.2 & 7.6 \\
\hline 09N04E30DCA1 & 352232 & 904218 & $8 / 4 / 2009$ & 491 & 24.2 & 7.8 \\
\hline \multicolumn{7}{|c|}{ Dallas County } \\
\hline 07S14W31AAA1 & 340425 & 923334 & $7 / 29 / 2009$ & 125 & 25.1 & 6.8 \\
\hline 10S13W34ACA2 & 334829 & 922458 & $7 / 29 / 2009$ & 277 & 24.9 & 7.3 \\
\hline \multicolumn{7}{|c|}{ Desha County } \\
\hline 09S02W26AAC1 & 335346 & 911521 & $7 / 31 / 2009$ & 284 & 24.3 & 8.1 \\
\hline 12S03W34DAD1 & 333643 & 912305 & $7 / 31 / 2009$ & 373 & 25 & 8.3 \\
\hline
\end{tabular}




\section{Water Levels and Water Quality in the Sparta-Memphis Aquifer (Middle Claiborne Aquifer) in Arkansas}

Appendix 3. Specific conductance, temperature and pH data from wells completed in the Sparta-Memphis aquifer in eastern Arkansas, summer 2009.-Continued

[Horizontal coordinate information is referenced to the North American Datum of 1983 (NAD 83); $\mu \mathrm{S} / \mathrm{cm}$, microsiemens per centimeter at 25 degrees Celsius]

\begin{tabular}{|c|c|c|c|c|c|c|}
\hline Station name & $\begin{array}{l}\text { Latitude } \\
\text { (degrees, } \\
\text { minutes, } \\
\text { seconds) }\end{array}$ & $\begin{array}{l}\text { Longitude } \\
\text { (degrees, } \\
\text { minutes, } \\
\text { seconds) }\end{array}$ & Date & $\begin{array}{c}\text { Specific } \\
\text { conductance } \\
(\mu \mathrm{S} / \mathrm{cm})\end{array}$ & $\begin{array}{c}\text { Temperature } \\
\text { (degrees Celsius) }\end{array}$ & $\begin{array}{c}\mathrm{pH} \\
\text { (standard units) }\end{array}$ \\
\hline \multicolumn{7}{|c|}{ Drew County } \\
\hline 11S05W21CDC1 & 334352 & 913724 & $7 / 30 / 2009$ & 256 & 27.2 & 8.1 \\
\hline 13S05W36ACB1 & 333151 & 913408 & $7 / 30 / 2009$ & 361 & 25.8 & 8.8 \\
\hline 05S13W03CAA1 & 341844 & 922400 & $7 / 29 / 2009$ & 89 & 22.3 & 6.4 \\
\hline 06S15W26ACA1 & 341022 & 923538 & $7 / 29 / 2009$ & 48 & 24.6 & 7.0 \\
\hline \multicolumn{7}{|c|}{ Jefferson County } \\
\hline 04S07W17BCC1 & 342140 & 914742 & $8 / 3 / 2009$ & 153 & 24.3 & 7.2 \\
\hline \multicolumn{7}{|c|}{ Lafayette County } \\
\hline 20S23W05ADB1 & 330223 & 933036 & $7 / 29 / 2009$ & 214 & 27.1 & 8.0 \\
\hline \multicolumn{7}{|c|}{ Lincoln County } \\
\hline 07S06W33BAA1 & 340445 & 914140 & $7 / 31 / 2009$ & 201 & 26 & 8.5 \\
\hline 08S05W35ACC1 & 335907 & 913337 & $7 / 31 / 2009$ & 244 & 25.4 & 8.8 \\
\hline 09S07W07DAD1 & 335634 & 915128 & $7 / 31 / 2009$ & 426 & 25.1 & 8.5 \\
\hline \multicolumn{7}{|c|}{ Lonoke County } \\
\hline 02N07W09AAA1 & 344906 & 914500 & $8 / 3 / 2009$ & 353 & 23 & 7.7 \\
\hline 14S21W04CCB1 & 333251 & 931708 & $7 / 29 / 2009$ & 201 & 25.8 & 7.1 \\
\hline 14S21W20AAB1 & 333050 & 931723 & $7 / 29 / 2009$ & 210 & 26.2 & 7.1 \\
\hline \multicolumn{7}{|c|}{ Ouachita County } \\
\hline 12S16W26BAA1 & 333948 & 924305 & $7 / 21 / 2009$ & 228 & 20.6 & 7.1 \\
\hline 12S19W14AAA1 & 334143 & 930105 & $7 / 29 / 2009$ & 43 & 26.2 & 7.2 \\
\hline 15S19W10DCC1 & 332618 & 930318 & 7/29/2009 & 203 & 25.8 & 6.9 \\
\hline \multicolumn{7}{|c|}{ Phillips County } \\
\hline 01S02E32DDC1 & 343324 & 905455 & $8 / 4 / 2009$ & 789 & 24.1 & 7.9 \\
\hline 03S05E05BAB1 & 342755 & 903621 & $8 / 4 / 2009$ & 793 & 20.7 & 8.0 \\
\hline 04S02E25CCC1 & 341824 & 905121 & $8 / 4 / 2009$ & 1,230 & 23.1 & 8.4 \\
\hline \multicolumn{7}{|c|}{ Poinsett County } \\
\hline 10N01E15DBB1 & 352931 & 905825 & $8 / 5 / 2009$ & 383 & 21.8 & 8.0 \\
\hline \multicolumn{7}{|c|}{ Prairie County } \\
\hline 02N06W20BCB1 & 344707 & 914033 & $8 / 5 / 2009$ & 380 & 21.9 & 7.3 \\
\hline
\end{tabular}


Appendix 3. Specific conductance, temperature and $\mathrm{pH}$ data from wells completed in the Sparta-Memphis aquifer in eastern Arkansas, summer 2009.-Continued

[Horizontal coordinate information is referenced to the North American Datum of 1983 (NAD 83); $\mu \mathrm{S} / \mathrm{cm}$, microsiemens per centimeter at 25 degrees Celsius]

\begin{tabular}{|c|c|c|c|c|c|c|}
\hline Station name & $\begin{array}{l}\text { Latitude } \\
\text { (degrees, } \\
\text { minutes, } \\
\text { seconds) }\end{array}$ & $\begin{array}{l}\text { Longitude } \\
\text { (degrees, } \\
\text { minutes, } \\
\text { seconds) }\end{array}$ & Date & $\begin{array}{c}\text { Specific } \\
\text { conductance } \\
(\mu \mathrm{S} / \mathrm{cm})\end{array}$ & $\begin{array}{c}\text { Temperature } \\
\text { (degrees Celsius) }\end{array}$ & $\begin{array}{c}\mathrm{pH} \\
\text { (standard units) }\end{array}$ \\
\hline \multicolumn{7}{|c|}{ St. Francis County } \\
\hline 05N03E33ABA2 & 350020 & 904713 & $8 / 4 / 2009$ & 517 & 19.7 & 7.5 \\
\hline \multicolumn{7}{|c|}{ Union County } \\
\hline 16S16W01DDD1 & 332114 & 924211 & $7 / 22 / 2009$ & 454 & 22.3 & 9.0 \\
\hline 16S18W34ABC2 & 331806 & 925709 & 7/29/2009 & 335 & 25.1 & 8.4 \\
\hline 17S13W31BAD1 & 331204 & 922907 & $7 / 22 / 2009$ & 762 & 25 & 8.9 \\
\hline 17S16W24BDB1 & 331357 & 924248 & $7 / 22 / 2009$ & 437 & 22.7 & 8.7 \\
\hline 19S15W01CCA1 & 330535 & 923645 & $7 / 30 / 2009$ & 325 & 23.2 & 8.2 \\
\hline 19S16W35DDC1 & 330109 & 924326 & $7 / 22 / 2009$ & 578 & 22.9 & 8.7 \\
\hline \multicolumn{7}{|c|}{ Woodruff County } \\
\hline 05N02W31DCB3 & 350027 & 911456 & $8 / 5 / 2009$ & 201 & 20.3 & 7.9 \\
\hline
\end{tabular}


